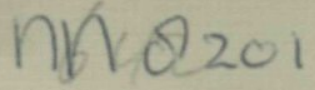

Model calculations

concerning economic optimalization of AI-breeding with cattle

E.W. Brascamp
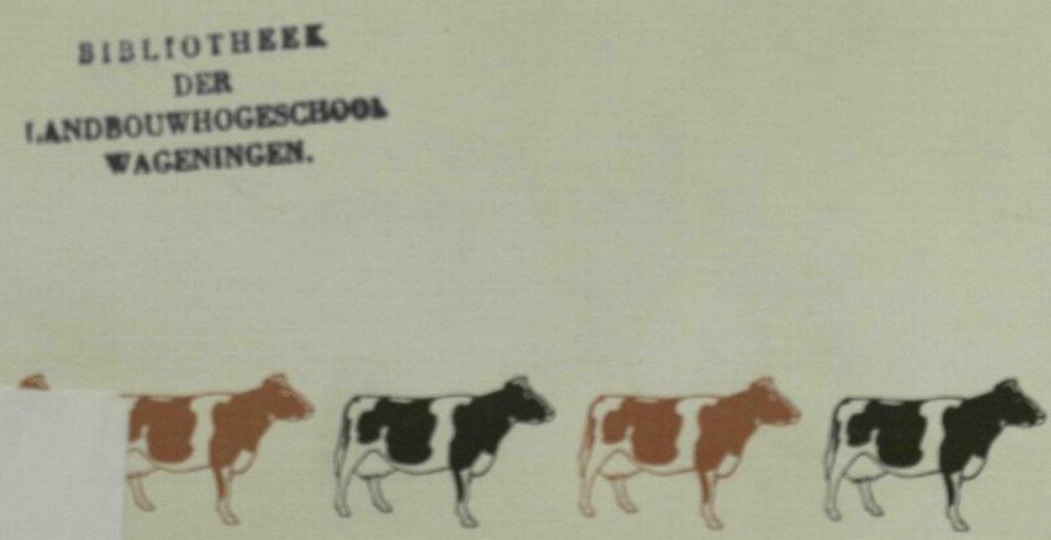

\title{
NN08201.642
}
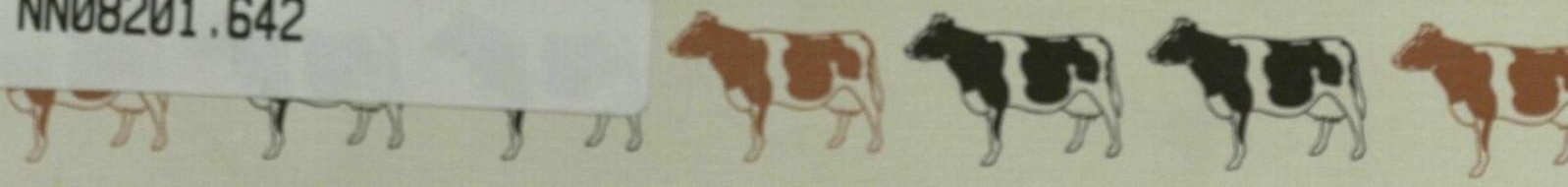
E. W. Brascamp

\section{Model calculations concerning economic optimalization of AI-breeding with cattle}

Proefschrift

ter verkrijging van de graad van

doctor in de landbouwwetenschappen,

op gezag van de rector magnificus,

dr. ir. J. P. H. van der Want, hoogleraar in de virologie, in het openbaar te verdedigen

op vrijdag 12 december 1975 des namiddags te vier uur in de aula van de Landbouwhogeschool te Wageningen

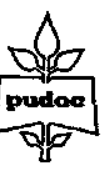

Centre for Agricultural Publishing and Documentation

Wageningen - 1975 


\section{Stellingen}

\section{I}

De erfelijke vooruitgang per jaar voldoet niet als maat voor het economisch rendement van fokprogramma's.

Dit proefschrift.

Il

Het 'koude-stierensysteem' is zelfs bij hogere kosten winstgevender dan het ProefWacht-Fokstieren (P.W.F.)-systeem zonder opslag van diepvriessperma gedurende de wachtperiode.

Dit proefschrift.

\section{III}

Intensivering van gebruikskruising van een melkvleesras met stieren van vleesrassen rechtvaardigt voor dat melkvleesras in de fokkerij een toenemende nadruk op melkproduktiekenmerken in vergelijking met vleesproduktiekenmerken.

Dit proefschrift.

E.P. Cunningham \& A. E. McClintock, 1974. Ann. Génét. Sél. Anim. 6: 227-239.

\section{IV}

Doordat de weging van kenmerken in een aggregaat genotype niet slechts afhangt van hun (relatieve) economische waarden, maar ook van hun frequentie en van het tijdstip van het tot uitdrukking komen van die kenmerken als produktiekenmerken, is het in veel gevallen nodig voor elke selectieweg afzonderlijk een aggregaat genotype te definiëren.

Dit proefschrift.

\section{V}

Bij indexselectie is (partiële) restrictie op de genetische verandering van kenmerken met een economische waarde nul niet realistisch. Anderzijds leidt het nul stellen van de economische waarde van kenmerken waarvoor (partiële) restrictie geldt, teneinde het effect van de restrictie te berekenen, in navolging van Cunningham et al., tot nietinformatieve uitkomsten.

E. P. Cunningham, T. Gjedrem \& R. A. Moen, 1970. Biometrics 26: 67-74. 
De suggestie van Dickerson, dat 'recombinatie-effecten' (berustend op additief $\times$ additief interacties) een negatieve invloed hebben op de waarde van een kruisingsprodukt, is voorbarig.

G. E. Dickerson, 1973. Proc. Animal Breeding and Genetics Symp. in honor of Dr Jay L. Lush, July 29, 1972. A.S.A.S., A.D.S.A., Champaign, 111. 61820, p. 54-77.

G. E. Dickerson, 1974. Proc. Working Symp. Breed Evaluation and Crossing Experiments with Farm Animals. Sept. 15-21, 1974. I.V.o. Zeist, p. 7-23.

\section{VII}

Bij het opsporen van probleembedrijven met behulp van parameters die berusten op gemiddelden van kengetallen voor dieren op een bedrijf, moet rekening worden gehouden met het aantal dieren waarover gemiddeld is.

\section{VIII}

Voor een snelle doorstroming van gegevens van onderzoek naar praktijk en omgekeerd, dienen onderzoekers deel te nemen aan de beleidsvorming van organisaties als Stamboeken, K.I.-verenigingen, C.M.D. en G.I.R.

IX

Het nut van het hanteren van het Nederlands in de omgang met hun kinderen door ouders die voor het overige in het dagelijks leven dialect spreken, moet niet worden overschat.

\section{$\mathbf{X}$}

Het appelleren aan het boerenverstand dient de voornaamste pijler te zijn van (ondersteunend) statistisch onderwijs. 


\section{Abstract}

Brascamp, E. W. (1975) Model calculations concerning economic optimalization of AI-breeding with cattle. Agric. Res. Rep. (Versl. landbouwk. Onderz.) 846, ISBN 9022005941 , (v) +40 p., 30 refs. Eng. and Dutch summaries. This publication partly is a summary of work published in Z. Tierz. Züchtungsbiol. 90 (1973) 1-15; 126-140; 91 (1974) 176-187.

Also: Doctoral thesis, Wageningen.

The effect of costs on the optimum breeding plan for selection for milk traits and the profitability of performance-test selection according to meat production were studied, including the consequences of beef crossing. Returns from breeding schemes were calculated from the expression of genetic superiority of selected parents (paths) in subsequent generations of offspring. Measuring the contribution of separate paths to returns was based on 'discounted expressions per cow'. The relative contribution of paths to returns and to annual genetic improvement differed, especially for path sire to breed daughter, showing a higher relative contribution to returns than to genetic improvement. A breeding plan with highest net returns (returns minus costs) was designated as optimum. Two types of breeding plans for selection for milk traits were compared: a system with semen storage during the waiting period and including slaughtering of bulls after production of a predetermined number of doses, and a system without semen storage. The first system proved to be economically advantageous. Optimum proportion selected, after performance testing, was between 1 in 2 and 1 in 4. Optimum weighing of milk and meat traits - the product of actual economic values and discounted expressions per cow - differed by path, and increasing proportion of beef crossing resulted in a shift of emphasis to milk traits. The conclusions remained unaltered if returns per cow from the expression of genetic superiority were calculated in subsequent years instead of generations, even though the generation approach gave systematic errors in discounted expressions.

Descriptors: gene flow, net returns, milk yield, performance test, beef crossing. 
Chapter 2 of this thesis summarizes the following papers:

1973 Model calculations concerning economic optimalization of AI-breeding with cattle. I. The economic value of genetic improvement in milk yield. $Z$. Tierz. Züchtungsbiol. 90: 1-15.

1973 Model calculations concerning economic optimalization of AI-breeding with cattle. II. Effect of costs on the optimum breeding plan. Z. Tierz. Züchtungsbiol. 90: 126-140.

1974 Model calculations concerning economic optimalization of AI-breeding with cattle. III. Profitability of performance testing in a dual-purpose breed according to meat production and the effect of beef crossing. Z. Tierz. Zuichtungsbiol. 91 : 176-187. 


\section{Voorwoord}

Het idee voor het onderwerp van dit proefschrift werd mij aan de hand gedaan door prof. dr. R. D. Politiek tijdens zijn spreekuur op 6 februari 1969. Tevens beval hij mij als praktijk aan een verblijf op het Instituut voor Veeteeltkundig Onderzoek in Zeist, bij ir. D. Minkema, en aan de Landbouwhogeschool te Ås (Noorwegen), bij prof. dr. H. Skjervold. Gedurende de beide praktijkperiodes schoof het onderwerp naar de achtergrond, maar de drie maanden in Âs resulteerden in een onderzoeksperiode van september 1971 tot juni 1972 aan Instituttet for Husdyravl aldaar, wat mogelijk werd gemaakt door een beurs van de Noorse regering. In die periode is met het onderzoek voor dit proefschrift begonnen, en ik ben prof. Harald Skjervold, en vooral ook Erling Fimland, veel dank verschuldigd voor de gegeven steun.

Mijn promotor, prof. dr. R. D. Politiek, heeft vanaf het begin de ontwikkelingen nauwlettend gevolgd, en ik ben hem zeer erkentelijk voor de mogelijkheden die hij mij geboden heeft.

Toen ik in juni 1972 de werkzaamheden in Wageningen begon, werd ik opgenomen in de enthousiaste vakgroep van prof. Politiek, en vooral Henk Bakker, Wim Cöp en Jan Dommerholt hebben door hun bereidheid zich steeds te verdiepen in de problemen van mijn onderzoek sterk bijgedragen tot de gedachtenvorming.

De revisie van het proefschrift, alsmede van de twee laatste artikelen, is verzorgd door medewerkers van het Pudoc; deze instelling heeft tevens zorg gedragen voor de uitgave van het proefschrift. 


\section{Curriculum vitae}

E. W. Brascamp werd geboren op 1 maart 1948 te Olst. Na het behalen van het einddiploma HBS-B aan de Rijks-HBS te Deventer in 1965 begon hij in september van dat jaar met zijn studie aan de Landbouwhogeschool te Wageningen. Gedurende de ingenieursstudie was hij voor het hoofdvak Veeteelt werkzaam bij prof. dr. H. Skjervold aan Norges Landbrukshøgskolen te Ås (Noorwegen), en hij slaagde in april 1972 met lof voor het doctoraalexamen; keuzevakken waren Wiskunde en Erfelijkheidsleer. Het in Ås aangevangen onderzoek werd hierna voortgezet gedurende een promotie-assistentschap bij prof. dr. R. D. Politiek op de afdeling Veeteelt te Wageningen. Sinds begin 1974 is de auteur aan deze afdeling verbonden als wetenschappelijk medewerker. Het promotieonderzoek is in augustus 1975 afgerond. 


\section{Contents}

List of symbols $\quad 1$

1 Introduction 3

2 Summaries of papers 5

2.1 Paper I: The economic value of genetic improvement in milk yield 5

2.2 Paper II: Effect of costs on the optimum breeding plan 6

2.3 Paper III: Profitability of performance testing in a dual-purpose breed according to meat production and the effect of beef crossing 8

3 Comparison of generation approach and year approach 9

3.1 Year approach: methods $\quad 9$

3.2 Results of comparison 15

3.2.1 Discounted expression per cow: comparison of methodology 15

3.2.2 Discounted expressions per cow for milk traits (Paper 1) 19

3.2.3 Discounted expressions per cow for meat traits (Paper III) 21

3.2.4 Optimum breeding plans for milk traits (Paper II) 22

4 General discussion $\quad 24$

$\begin{array}{ll}\text { Summary } & 28\end{array}$

$\begin{array}{lr}\text { Samenvatting } & 29\end{array}$

References $\quad 33$

Appendix 1: Multiplication matrix P (for milk traits) 35

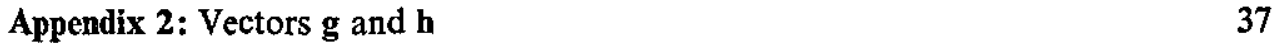

Appendix 3: Multiplication matrix M (for meat traits) 39 


\section{List of symbols}

For symbols used in Papers I, II and III see Appendices of respective papers. Symbols used in this text are summarized below.

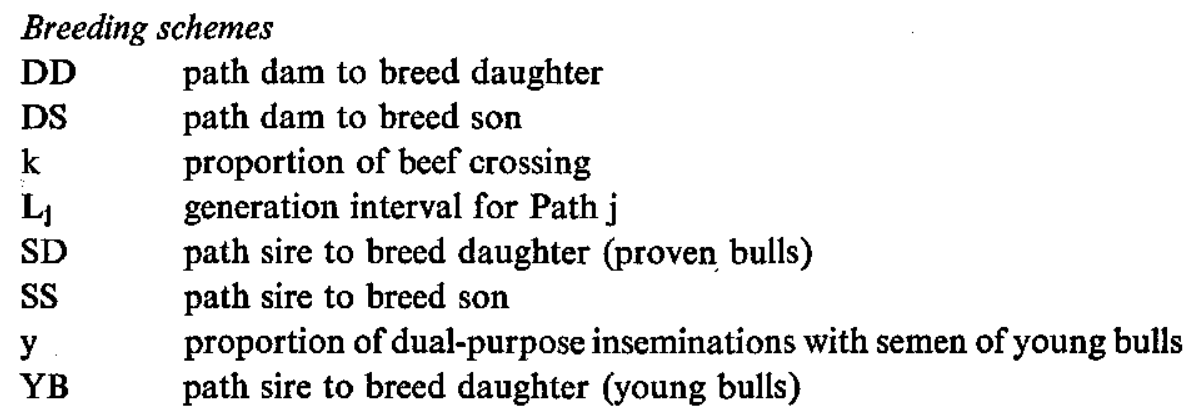

\section{Population structure}

A probability that a first insemination (including repeats) by a young bull results in a dairy replacement $(\mathrm{k}=0)$

B the same probability for inseminations of proven bulls

C average number of lactations per cow

$\Delta \mathrm{G} \quad$ genetic improvement per year

The dimension of all following vectors is $m \times 1$, where $m$ is given by the sum of the number of age classes in males and females.

g vector with fractions of lactating cows in age classes

h vector with relative phenotypic merit of lactating cows in age classes

$l_{j}(t) \quad$ vector with the genetic makeup for meat traits of slaughter animals of Age 1 in Year $t$. Transmission of genes to the first generation is via Path jonly

$m(t) \quad$ vector with the genetic makeup by reproduction and ageing for milk traits of animals in Year $t$ in relation to the initial situation $\mathbf{m}(0)$

$m_{j}(t)$ the same vector as $m(t)$ except that transmission of genes to first-generation offspring is via Path $\mathbf{j}$ only. The initial situation is given by $\mathbf{n}(0)$

$n(t) \quad$ vector with the genetic makeup by ageing for milk traits in Year $t$. The initial situation is $\mathbf{n}(0)$

$\mathbf{z}$ vector with the fraction of all calves born in a year kept for slaughter

The dimension of all following square matrices is given by the sum of the number 
of age classes in males and females. The matrices show reproduction by paths or ageing of breeding animals.

M matrix showing reproduction for meat traits

$\mathbf{N}_{\mathbf{j}} \quad$ matrix showing reproduction for meat traits via Path $\mathbf{j}$ only

$\mathbf{P}$ matrix showing reproduction for milk traits and ageing of breeding animals

Q matrix showing ageing of breeding animals

$\mathbf{R}_{\mathbf{j}} \quad$ matrix showing reproduction for milk traits via Path $\mathbf{j}$ only

$\mathbf{N} \quad$ population size

s proportion of purebred dual-purpose calves surviving to slaughter age

$s_{i} \quad$ proportion of purebred dual-purpose calves from dams of Age Class $i$ surviving to slaughter age

$s^{\prime} \quad$ proportion of crossbred calves for meat production surviving to slaughter age

si proportion of crossbred calves for meat production from dams of Age Class i surviving to slaughter age

S proportion of calves surviving to slaughter age

Economic evaluation

$\delta_{j t} \quad$ discounted expression per cow for milk traits for Path $\mathbf{j}$ in an isolated Year $\mathbf{t}$

$\varepsilon_{\mathrm{jt}} \quad$ discounted expression per cow for meat traits for Path $\mathrm{j}$ in an isolated Year $\mathrm{t}$

$r$ interest rate 


\section{Introduction}

Research on cattle breeding can be divided into three major areas: aim of breeding; assessment of breeding values; structure of breeding programmes.

It is recognized that the value of cattle for breeding depends on numerous traits. For an operational breeding objective an aggregate genotype can be defined by finding the relative (economic) weights of traits to be selected for. Niebel et al. (1972) showed for dual-purpose cattle that for the German situation milk yield (and components) together with growth rate or feed conversion ratio were by far the most important traits in the aggregate genotype.

An aspect of the second area of research is the analysis of (field) data to obtain reliable estimates of the breeding values as a basis for selection.

In the third area the breeding programme is the subject of research: what form should the breeding plan take to maximize the selection results for the population?

A powerful tool for genetic improvement of cattle is artificial insemination. It enables us to obtain reliable estimates of the breeding value of a bull for traits which can not be measured as the bull's own performance and the number of descendants of a (superior) bull can become very large.

This thesis deals with the third question: optimization of breeding plans using AI within a dual-purpose breed of cattle with respect to selection for milk and meat traits. The criterion for which a breeding scheme should be optimized has changed during the last decades. Skjervold \& Langholtz (1964) studied genetic improvement resulting from a breeding scheme. It was realized, however, that schemes with maximum genetic improvement were probably too expensive and so, from an economic view point, not optimum. Skjervold (1966) suggested that schemes giving about $90 \%$ of maximum genetic improvement were near the economic optimum. Lindhe (1968) included cost calculations while monetary returns were calculated as a linear function of annual genetic improvement $(\Delta \mathrm{G})$. $\Delta \mathrm{G}$ was calculated according to Rendel \& Robertson (1950). Other methods to calculate monetary returns have been developed by Hinks (1971), Hill (1971) and McClintock \& Cunningham (1972). Estimation of monetary returns was not based on $\Delta \mathrm{G}$ but on the expression of genetic improvement in time according to the pattern by which genes of selected parents are passed on in the population. These methods, however, are not easily incorporated in a model calculation. Recently, Hill (1974) published a general method to evaluate by matrix procedures monetary returns from breeding schemes based on the pattern of passing on genes in a population.

The basis of this thesis is formed by three papers dealing with optimum breeding 
programmes for selection for milk traits and with the profitability of performancetest selection for meat traits. Some results are reconsidered in view of Hill's method.

In the first paper (summarized in Section 2.1) a method is developed to estimate monetary returns from selection for milk traits, which could be used in model calculations. Expression of genetic improvement in subsequent generations is the basis for this method.

The effect of costs on the optimum breeding plan to select for milk traits is studied in the second paper (summarized in Section 2.2).

Meat production can be improved genetically by selection within dual-purpose breed and by beef crossing. In the third paper (summarized in Section 2.3) the method to estimate returns is extended for meat traits and the profitability of performance testing in a dual-purpose breed according to meat production is examined. Consequences of crossing the dual-purpose breed with bulls of beef breeds, to produce slaughter animals, are studied.

Comparison of the method of Hill (1974) and that developed in the first paper is the subject of Chapter 3. Return calculations by Hill's method are based on the expression of genetic improvement in subsequent years whereas the calculations in the three papers are based on subsequent generations. 


\section{Summaries of papers}

The papers which are part of this thesis are:

- Paper I, The economic value of genetic improvement in milk yield. Z. Tierz. Züchtungsbiol. 90 (1973) 1-15.

- Paper II, Effect of costs on the optimum breeding plan. Z. Tierz. Züchtungsbiol. 90 (1973) 126-140.

- Paper III, Profitability of performance testing in a dual-purpose breed according to meat production and the effect of beef crossing. $Z$. Tierz. Zuichtungsbiol. 91 (1974) 176-187.

In the three papers deterministic models have been used. The most important parameters whose values were varied, are summarized below.

\section{Parameter}

population size

proportion in milk recording

proportion of beef crossing

proportion of dual-purpose inseminations with young bulls

progeny group size

number of doses per bull

number of doses produced per bull per year

$$
\begin{aligned}
& \text { range } \\
& 50000-1000000 \\
& 0.30-1.00 \\
& 0.00-0.70 \\
& \text { (approximately) } \\
& 0.10-0.90 \\
& 50-600 \\
& 3000-220000 \\
& 15000-35000
\end{aligned}
$$

\subsection{Paper I: The economic value of genetic improvement in milk yield}

The approach to calculate the economic value in milk yield is illustrated in Fig. 1. The closed circles in Fig. 1 represent batches of offspring from groups of parents for four generations. For each batch the number of (female) offspring entering the dairy herd can be calculated. By inclusion of the genetic relationship between selected parents and animals in a batch, the total genetic superiority of parents expressed by the cows in the batch is found. The units of this superiority are for instance, $\mathrm{kg}$ (of milk) or money units. To obtain the economic value of the total genetic superiority expressed in a batch of offspring, the monetary value is discounted to a reference year. The birth of young bulls (Parents YB in Fig. 1) is taken as reference year (Year 0). Summing the discounted value of genetic superiority for all batches results in the economic value of genetic improvement for all four generations.

Another approach (Lindhé, 1968; Lindström, 1971) to estimate the economic value 


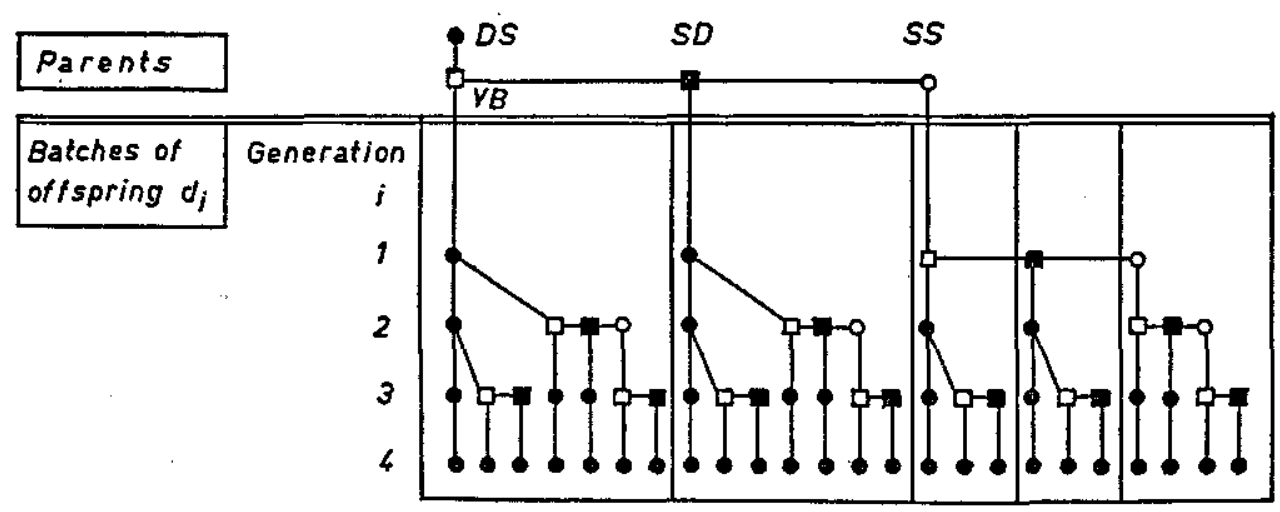

Fig. 1. The parents and the batches of offspring $\left(d_{i}\right)$ when four generations of offspring are taken into consideration.

DS = dams to breed son; YB = young bulls of generation zero; SD = sire to breed daughter; SS = sire to breed son; $=$ batch of offspring; $\square=$ young bulls; $\mathbf{m}=$ proven bulls to breed daughter; $O=$ sires to breed son.

of genetic improvement is based on the value of the annual genetic improvement $(\Delta G)$ estimated with the formula of Rendel \& Robertson (1950). The economic value of genetic improvement is then estimated as a linear function of $\Delta \mathrm{G}$.

For comparison of both approaches a discount factor was introduced for the time lag between Year 0 and the expression of genetic improvement in females in the population. This discount factor was calculated as the ratio between the estimate of the economic value of genetic improvement over four generations and the estimate made with the linear function of $\Delta \mathrm{G}$.

Conclusions can be summarized as follows: the relative contribution of Path SS (sire to breed son) to the monetary returns is lower than to $\Delta \mathrm{G}$. For Paths SD (proven bulls) and DD (dam to breed daughter) the opposite is true. The relative contribution of Path DS (dam to breed sire) to both returns and $\Delta \mathrm{G}$ is about equal.

The discount factor for the time lag is not a constant. Most important is the increase of the discount factor with increasing numbers of doses of sperm per bull. The discount factor based upon $10 \%$ interest rate ranges from $0.28-0.30$ for 3000 doses per bull up to $0.35-0.40$ for 80000 doses per bull.

Further the effect of the decrease of the population size has been studied, assuming a decrease during about 25 years with a constant rate $q$ per year. The value of genetic improvement decreases roughly to $(1-q)^{16}$ times the value of genetic improvement when the population size is constant.

\subsection{Paper II: Effect of costs on the optimum breeding plan}

Gross returns were calculated with the method developed in Paper I. An interest rate of $10 \%$ was used to calculate gross returns. Costs based on cost factors summarized in Table 1 were calculated with an interest rate of $8 \%$. The data in Table 1 are 
relative to Cost alternative 1 , the assumed Norwegian situation.

The breeding plan with the largest difference between gross returns and costs (i.e. maximum net returns) was taken as the optimum. A suboptimum breeding plan was adopted to cover situations where one is not prepared to invest the amount of money in AI justified by the criterion maximum net returns. Such a suboptimum plan shows highest net returns given a certain cost level.

Two management systems were compared, the waiting-bull system $B$, and the system of storing deep-frozen semen and slaughtering the bulls as soon as a predetermined number of doses per bull has been stored: $A$.

For most cost alternatives, optimum and suboptimum breeding plans for System A were more profitable than those under System B. Under System A the number of doses per bull was high and the same for all these plans. Exceptions were cost alternatives with high costs for semen preparation and storage, and low costs for maintenance (Cost alternatives 4, 7 and 10). Then at low cost levels, suboptimum plans for System B were more profitable than those under System A, while for System A the suboptimum plans were characterized by a lower number of doses than the optimum plan.

Net returns of optimum and suboptimum plans increase with population size. In

Table 1a. Meaning of symbols and values of cost factors for Cost alternative 1.

\begin{tabular}{llcl}
\hline Symbol & Cost factor & Value & \\
a1 & milk price & 0.25 & Nkr per kg \\
a2 & carcass value & 10 & Nkr per kg slaughter weight \\
a3 & 'first year' & 2500 & Nkr per bull \\
a4 & maintenance & 7 & Nkr per bull per day \\
a5 & dose preparation & 0.17 & Nkr per dose \\
a6 & dose storage & 0.033 & Nkr per dose per year \\
a7 & building & see Appendix 2, Paper II \\
a8 & labour & 33000 & Nkr per man-year \\
\hline
\end{tabular}

Table 1b. Summary of cost alternatives. Costs relative to cost factor $a 1=1$ and to cost alternative $1=1$. See Paper II.

\begin{tabular}{|c|c|c|c|c|c|c|c|c|c|c|c|c|}
\hline \multirow[t]{2}{*}{ Cost factor } & \multicolumn{12}{|c|}{ Cost alternative } \\
\hline & 1 & 2 & 3 & 4 & 5 & 6 & 7 & 8 & 9 & 10 & 11 & 12 \\
\hline a1 & 1 & 1 & 1 & 1 & 1 & 1 & 1 & 1 & 1 & 1 & 1 & 1 \\
\hline a2 & 1 & 1 & 1 & 1 & 1 & 1 & 1 & 1 & 1 & 1 & 0.40 & 1.20 \\
\hline a3 & 1 & 5 & 1 & 1 & 1 & 1 & 1 & 1 & 0.5 & 1 & 2.0 & 6.0 \\
\hline a4 & 1 & 1 & 1 & 1 & 2 & 3 & 1 & 2 & 1.2 & 0.6 & 1.3 & 3.9 \\
\hline a5 & 1 & 1 & 2 & 3 & 1 & 1 & 5 & 0.5 & 2 & 3.7 & 0.13 & 0.4 \\
\hline a6 & 1 & 1 & 1 & 1 & 1 & 1 & 5 & 0.5 & 0.75 & 0.75 & 0.30 & 0.9 \\
\hline a7 & 1 & 1 & 1 & 1 & 1 & 1 & 1 & 1 & 1 & 1 & 0.35 & 1 \\
\hline a8 & 1 & 1 & 1 & 1 & 1 & 1 & 1 & 1 & 1 & 1 & 0.55 & 1.65 \\
\hline
\end{tabular}


the model, however, cost factors were independent of population size. So no optimum population size could be determined.

2.3 Paper III: Profitability of performance testing in a dual-purpose breed according to meat production and the effect of beef crossing

The method developed in Paper I was extended for meat traits to estimate gross returns from performance-test selection for meat traits within a dual-purpose (milk/ meat) breed.

The concept 'discounted expression per cow' was introduced to estimate monetary returns from performance-test selection and to determine optimum weighing of milk traits and meat traits in an aggregate genotype. The discounted expression for a trait and a path was defined as the discounted gross returns from that expression of a trait in offspring which results from parental genetic superiority of one money unit, divided by the population size. This concept is similar to the 'number of standard discounted expressions' of McClintock \& Cunningham (1972).

The effect of beef crossing on the profitability of performance testing and on the weighing of milk and meat traits in an aggregate genotype was studied.

The major conclusions are summarized below:

Profitability of performance testing mainly depends on the selection intensity of bull dams, the relative economic value of milk and meat traits, costs and the fraction of beef crossing. The optimum proportion selected seems to be between 1 in 2 and 1 in 4. Generally the profitability of performance testing within the dual-purpose breed decreases when the fraction of beef crossing increases.

The optimum weighing of milk and meat traits in the aggregate genotype is the product of their actual economic value and their discounted expression per cow. This weighing is different for each path and the emphasis on milk and meat traits shifts to milk traits when the fraction of beef crossing increases. 


\section{Comparison of generation approach and year approach}

In Papers I and III discounted expressions per cow have been calculated for four generations. With these discounted expressions returns from breeding schemes have been calculated in Papers II and III. In this chapter discounted expressions per cow are calculated for a certain number of years, instead of for a number of generations. These calculations are done with the method described by Hill (1974). In Section 3.1 that part of Hill's approach needed to calculate discounted expressions per cow is explained. This approach is illustrated with an example. Further some extensions are described. The notation of Hill (1974) is followed.

In Section 3.2 the methodology of calculating discounted expressions based upon generations is compared with the approach based upon years for the example situation. Discounted expressions as given in Papers I and III (four-generations approach) are compared with discounted expressions based upon years. Assumptions used in these calculations are consistent with those in Papers I and III and are given in appendices. Implications for the conclusions of the papers will be discussed.

\subsection{Year approach: methods}

The crucial question in Hill's approach is: which part of the genes (genetic superiority) of a certain group of animals (selected parents) is expressed in animals in subsequent years. Let us consider this in a simple unrealistic example, in which bulls produce female offspring when they are 2 years of age (untested young bulls, YB) and when they are 4 years old (proven bulls, SD). Bulls (SS) produce male offspring (young bulls) when they are 4 years of age. Females (DS and DD) survive up to 3 years of age and produce an equal number of offspring at 2 and 3 years old.

The genetic makeup of sexes and age classes starting from bulls of Age 1 in Year 0 is given in Table 2 for this example. In Year 0 only bulls of Age 1 contain 100\% of their own genes. In Year 1 these bulls are one year older, so Age class 2 contains $100 \%$ of the genes of bulls of Age class 1 in Year 0. In Year 1 the bulls reach reproductive age. So in Year 2 the females of Age class 1 contain $10 \%$ of the genes of the bulls considered, as young bulls perform $20 \%$ of the inseminations and transmit $50 \%$ of their genes to an offspring. In Year 2 bulls of Age class 3 and females of Age class 1 contain genes of bulls considered but they are not of reproductive age. So from Year 2 to Year 3 the animals only grow one year older and have no offspring.

In Year 4, bulls of Age class 1 contain $50 \%$ of the genes of bulls considered transmitted by the bull fathers of Year 3. Further they contain $\frac{1}{2} \times 0.5 \times 10 \%=2.5 \%$ of 


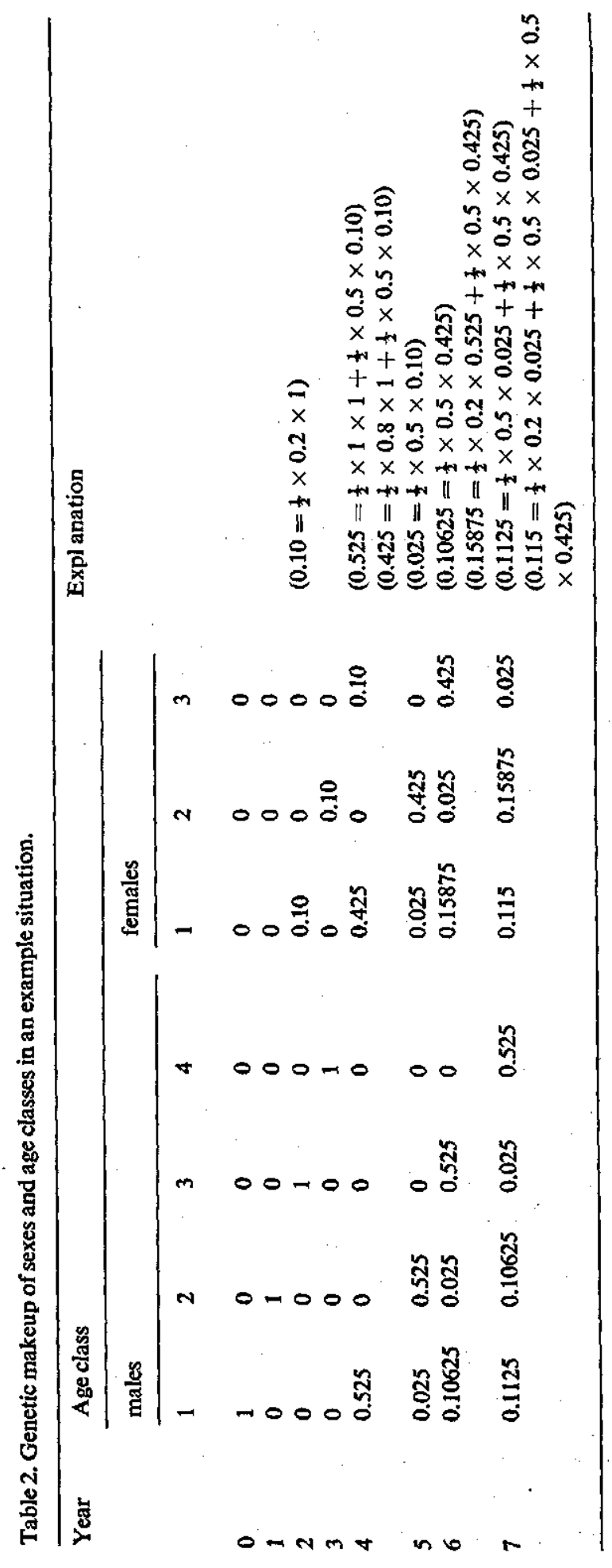


genes from cows of Age class 2. The remaining $\frac{1}{4}$ they get from cows of Age class 3, but the latter contain no genes of bulls considered. Females of Age class 1 contain $40 \%$ of genes transmitted by proven bulls and $2.5 \%$ transmitted by cows of Age class 3 $\left(\frac{1}{2} \times 0.8 \times 1+\frac{1}{2} \times 0.5 \times 0.10=0.425\right)$.

This process of ageing and reproduction can be formalized as follows. Define a Matrix $\mathbf{P}$ as

$$
\mathbf{P}=\left[\begin{array}{lllllll}
0 & 0 & 0 & 0.5 & 0 & 0.25 & 0.25 \\
1 & 0 & 0 & 0 & 0 & 0 & 0 \\
0 & 1 & 0 & 0 & 0 & 0 & 0 \\
0 & 0 & 1 & 0 & 0 & 0 & 0 \\
0 & 0.1 & 0 & 0.4 & 0 & 0.25 & 0.25 \\
0 & 0 & 0 & 0 & 1 & 0 & 0 \\
0 & 0 & 0 & 0 & 0 & 1 & 0
\end{array}\right]
$$

The blocks in $\mathbf{P}$ correspond to paths of gene transmission

$\left[\begin{array}{l}\text { sire to breed } \\ \text { son (SS) } \\ \text { sire to breed } \\ \text { daughter } \\ \text { (YB and SD) }\end{array}\right.$

dam to breed
son (DS)
dam to breed
daughter
(DD)

The Matrix $\mathbf{P}$ describes reproduction and ageing for the example in Table 2. The actual makeup of $\mathbf{P}$ is given in Appendix $\mathbf{1 .}$

Ageing alone can be described by a Matrix $\mathbf{Q}$ :

$$
\mathbf{Q}=\left[\begin{array}{lllllll}
0 & 0 & 0 & 0 & 0 & 0 & 0 \\
1 & 0 & 0 & 0 & 0 & 0 & 0 \\
0 & 1 & 0 & 0 & 0 & 0 & 0 \\
0 & 0 & 1 & 0 & 0 & 0 & 0 \\
0 & 0 & 0 & 0 & 0 & 0 & 0 \\
0 & 0 & 0 & 0 & 1 & 0 & 0 \\
0 & 0 & 0 & 0 & 0 & 1 & 0
\end{array}\right]
$$

A column vector $m(t)$ describes the genetic makeup of sexes and age classes in Year $t$, starting from the situation in Year $0, m(0)$. So

$$
\begin{aligned}
& \mathrm{m}^{\prime}(0)=\left(\begin{array}{llll|llll}
1 & 0 & 0 & 0 & 0 & 0 & 0
\end{array}\right) \text { and } \\
& \mathrm{m}^{\prime}(5)=\left(\begin{array}{llllllll}
0.025 & 0.525 & 0 & 0 & \mid & 0.025 & 0.425 & 0
\end{array}\right)
\end{aligned}
$$

Now

$$
\mathbf{m}(\mathrm{t}) \quad=\mathbf{P} \mathbf{m}(\mathrm{t}-1)=\mathbf{P}^{\mathrm{t}} \mathbf{m}(0)
$$


The genetic makeup of sexes and age classes by reproduction alone is given by

$$
\mathbf{m}(\mathrm{t})=\left(\mathbf{P}^{\mathrm{t}}-\mathbf{Q}^{\mathrm{t}}\right) \mathbf{m}(0) \quad \text { (Hill, 1974) }
$$

Milk traits Returning to the example, let us consider what the previous reasoning means in terms of genetic improvement of milk traits. Suppose that the genetic superiority of young bulls (by selection of bull dams, see Fig. 1), is $1 \mathrm{~kg}$ of milk. Then the first returns are attained in Year 3 when the average superiority of cows in Age class 2 is $0.10 \mathrm{~kg}$ of milk. Per cow in Year 3 this is $0.05 \mathrm{~kg}$ because only half of the lactating cows in a year are of Age 2.

The discounted expression per cow $\left(\delta_{3}\right)$ in Year 3 can be calculated as $0.05 \times\left(\frac{1}{1+\mathrm{r}}\right)^{3}$.

Here $r$ stands for the interest rate and discounting is done to the value in Year 0 . (The actual monetary value of $1 \mathrm{~kg}=1$ ). This can be formalized as

$$
\delta_{t}=m^{\prime}(t) h\left(\frac{1}{1+r}\right)^{t}
$$

In the example $\mathbf{h}^{\prime}=\left(\begin{array}{llll|lll}0 & 0 & 0 & 0 & 0 & 0.5 & 0.5\end{array}\right)$, the proportion of lactating cows in different age classes. In reality, however, the proportion of lactating cows in different age classes will not be equal. Furthermore, the average level and standard deviation of production in different lactations will not be equal. These effects should be included in $\mathbf{b}$. The vector of fractions of lactating cows in different age classes will be noted here as $\mathbf{g}$. For the actual assumptions of $\mathbf{g}$ and $\mathbf{h}$ see Appendix 2. Now the (cumulative) discounted expression per cow up to Year $t$ is obtained by adding all $\delta_{1}$ from Year $i=0$ to $i=t$.

To be in line with Paper I and Paper III cumulative discounted expressions per cow will be calculated for each path separately. In the example, the female offspring of Path SS will first lactate in Year 7 (Table 2) containing a fraction $\frac{1}{2} \times 0.2 \times 0.5=$ 0.05 of the genetic superiority of SS. For Path SD the first lactation occurs in Year 5 , cows of Age class 2 containing $\frac{1}{2} \times 0.8 \times 1=0.4$ of the SD genetic superiority. This splitting of selection response by paths can be formalized by

$$
\begin{aligned}
& \mathbf{n}(\mathbf{t})=\mathbf{Q}^{\mathbf{t}} \mathbf{n}(0) \\
& \mathbf{m}_{\mathbf{j}}(\mathrm{t})=\mathbf{R}_{\mathbf{j}} \mathbf{n}(\mathrm{t}-1)+\mathbf{P} \mathbf{m}_{\mathbf{j}}(\mathrm{t}-1)
\end{aligned}
$$

$\mathbf{n}(0)=\mathbf{m}(0)$, and $\mathbf{m}_{\mathfrak{J}}(t)$ represents the genetic makeup of sexes and age classes in Year $t$ for Path $j$. The vector $m_{j}(0)$ contains zeroes only. So for an isolated Year $t$

$$
\delta_{j t} \quad(t=m)_{j}^{\prime} \mathbf{h}\left(\frac{1}{1+r}\right)^{t}
$$

where $\delta_{\mathrm{gt}}$ is the discounted expression per cow for Path $\mathrm{j}$ in an isolated Year $t$.

In the example the $\mathbf{R}_{\mathbf{j}}$ matrices for Path YB and SD are 


$\begin{aligned} \mathbf{R}_{\mathbf{Y B}}= & {\left[\begin{array}{lllllll}0 & 0 & 0 & 0.5 & 0 & 0 & 0 \\ 0 & 0 & 0 & 0 & 0 & 0 & 0 \\ 0 & 0 & 0 & 0 & 0 & 0 & 0 \\ 0 & 0 & 0 & 0 & 0 & 0 & 0 \\ 0 & 0.1 & 0 & 0.4 & 0 & 0 & 0 \\ 0 & 0 & 0 & 0 & 0 & 0 & 0 \\ 0 & 0 & 0 & 0 & 0 & 0 & 0\end{array}\right] } \\ \mathbf{R}_{\mathrm{SD}} & =\left[\begin{array}{lllllll}0 & 0 & 0 & 0 & 0 & 0 & 0 \\ 0 & 0 & 0 & 0 & 0 & 0 & 0 \\ 0 & 0 & 0 & 0 & 0 & 0 & 0 \\ 0 & 0 & 0 & 0 & 0 & 0 & 0 \\ 0 & 0 & 0 & 0.4 & 0 & 0 & 0 \\ 0 & 0 & 0 & 0 & 0 & 0 & 0 \\ 0 & 0 & 0 & 0 & 0 & 0 & 0\end{array}\right]\end{aligned}$

$\mathbf{R}_{S S}$ contains only the SS reproduction part of matrix $\mathbf{P}$.

For the Paths SS, SD and YB the $n(0)$ vector equals $n^{\prime}(0)=\left(\begin{array}{llll|ll}1 & 0 & 0 & 0 & 0 & 0\end{array}\right.$ 0 ) in the example; or generally, $\mathbf{n}(0)$ contains all zeroes except males in Age class 1.

Equation (4) gives only. ageing of the initial bulls. Note that $\mathbf{Q}^{t} \mathbf{n}(0)=\mathbf{0}$ when $t \geqslant$ (number of male age classes) (Hill, 1974). The part $\mathbf{R}_{\mathfrak{f}} \mathbf{n}(t-1)$ of Eqn 5 gives the genetic makeup of the offspring of the first generation, only via the path considered. The part $\mathbf{P} \mathbf{m}_{f}(\mathrm{t}-1)$ gives reproduction of this first generation offspring and of later generations. This structure of separating reproduction by paths is seen also in Fig. 1.

The discounted expressions per cow for Path DS equal half those of Path YB, as follows from the position of DS in Fig. 1.

Meat traits Animals for breeding are produced via five paths: SS, SD, YB, DS and DD. All calves surviving to age of slaughter, except breeding animals and cows kept for milk production, are regarded as slaughter animals. So bullfathers (SS) and bulldams (DS) do not transmit genes directly to slaughter animals. Slaughter animals contain genes from dual-purpose breed parents YB, SD and DD, and possibly from bulls of beef breeds. Thus the genetic makeup of slaughter animals in Year $t$ can be calculated as

$$
\mathbf{l}_{j}(\mathrm{t})=\mathbf{N}_{\mathrm{j}} \mathbf{n}(\mathrm{t}-1)+\mathbf{M} \mathbf{m}_{\mathrm{j}}(\mathrm{t}-1)
$$

It should be mentioned that $m_{j}(t-1)$ in Eqn 7 is calculated from Eqn 5 .

Matrix $\mathbf{M}$ contains reproduction of slaughter animals via Path YB, SD and DD. Matrix $\mathbf{N}_{\mathrm{j}}$ contains reproduction of slaughter animals only via Path $\mathbf{j}$. If all other elements of matrices $M$ and $N_{j}$ are put equal to zero, $I_{j}(t)$ will contain zeroes except 
female Age class 1. This element represents the genetic makeup of all slaughter animals, irrespective of sex, at Age 1 in Year $j$.

In the example Matrix $M$ will equal

\begin{tabular}{|c|c|c|c|c|c|c|c|}
\hline & 0 & 0 & 0 & 0 & 0 & 0 & 0 \\
\hline & 0 & 0 & 0 & 0 & 0 & 0 & 0 \\
\hline & 0 & 0 & 0 & 0 & 0 & 0 & 0 \\
\hline $\mathbf{M}=$ & 0 & 0 & 0 & 0 & 0 & 0 & 0 \\
\hline & 0 & 0.1 & 0 & 0.4 & 0 & 0.25 & 0.25 \\
\hline & 0 & 0 & 0 & 0 & 0 & 0 & 0 \\
\hline & 0 & 0 & 0 & 0 & 0 & 0 & 0 \\
\hline
\end{tabular}

For Path YB m $\operatorname{YB}_{\mathrm{YB}}^{\prime}(5)=\left(\begin{array}{llll|lll}0.025 & 0.525 & 0 & 0 & 0.025 & 0.425 & 0\end{array}\right)$. Pre-multiplication of $m_{Y B}(5)$ by Matrix $M$ gives as the only non-zero element of $l_{Y B}(6): 0.1 \times 0.525$ $+0.25 \times 0.425=0.15875$, representing the fraction of young bulls' initial genetic superiority for meat inherited by all slaughter animals of Age 1 in Year 6.

$\mathbf{N}_{\text {SS }}$ contains zeroes only. $\mathbf{N}_{\text {SD }}$ contains the reproduction part for SD in Matrix $M$ (in the example 0.4 and zeroes), and $\mathrm{N}_{\mathrm{YB}}$ the reproductive part of bulls (in the example 0.10 and 0.40 and zeroes).

The actual makeup of Matrix $\mathbf{M}$ is more complicated if beef crossing is considered. In Appendix 3 the actual makeup of Matrix $\mathbf{M}$ is derived.

Discounted expressions per cow for meat traits for Path $j$ in an isolated Year $t$ $\left(\varepsilon_{\mathrm{jt}}\right)$ can be calculated as

$$
\varepsilon_{\mathrm{jt}}=\mathrm{l}_{\mathrm{j}}^{\prime}(\mathrm{t}) \mathrm{z}\left(\frac{1}{1+\mathrm{r}}\right)^{\mathrm{t}}
$$

where $\mathbf{z}$ is a vector containing zeroes except the element female Age class 1. This element equals the proportion of all calves born in one year surviving to age of slaughter (S). Animals are taken to be slaughtered at one year of age, simply as a result of the definition of matrices. If animals are slaughtered at a different time, extra discounting is needed.

\section{Remarks}

- The DD part of Matrix $\mathbf{M}$ will only equal the reproduction part of $\mathrm{DD}$, Matrix $\mathbf{P}$, if slaughter animals inherit genes from dams in different age classes at the same frequency as the calves for female replacement. In practice this assumption will not hold. For example, a daughter of an older cow will be kept for replacement rather than a daughter of a heifer. In notation used here, the DD part of the $\mathbf{M}$ and $\mathbf{P}$ matrices mentioned will only be equal when reproduction via $P a t h D D$ is given by $\frac{1}{2} g$, vector $g$ containing the fraction of cows in subsequent lactations.

- The reproduction part of matrices $\mathbf{M}$ and $\mathbf{P}$ for the paths males to females will only be equal to each other if daughters of young bulls and of proven bulls have an 
equal chance to become replacement heifers, and if no beef crossing is practised, as milking cows do not contain beef breed genes, but slaughter calves do.

\subsection{Results of comparison}

In this section two methods to estimate discounted expressions per cow will be compared with the example of the previous section (Table 2). In addition results from both approaches will be discussed. The two methods are based upon:

- generations (Papers I and III; Chapter 2)

- years (Section 3.1).

The discounted expression per cow for Trait $i$ and Path $j$ has been defined as the discounted gross returns from that expression of $i$ in offspring which results from genetic superiority of parents (Path $\mathrm{j}$ ) of one money unit, divided by the population size. The discounted expression for milk traits in two batches of offspring extracted from Fig. 1 will be calculated by both methods.

\subsubsection{Discounted expression per cow: comparison of methodology}

Case 1 Consider the batch of offspring from young bulls (in Generation 1) in Fig. 2. (This is a part of Fig. 1). Suppose that the population size is N. Since young bulls perform $20 \%$ of the first inseminations and the replacement rate is $\frac{1}{2}$, the number of offspring in Batch 1 entering the dairy herd will be $0.2 \times \mathrm{N} \times \frac{1}{2}$. These offspring will have $2 \times 0.2 \times \mathrm{N} \times \frac{1}{2}$ lactations. The genetic relationship between the young bulls and their offspring is $\frac{1}{2}$, so, if the genetic superiority of young bulls is one money unit, the total increase in milk production in Batch 1 is $\frac{1}{2} \times 2 \times 0.2 \times \mathrm{N} \times \frac{1}{2}=\frac{1}{2} \times 0.2$ $\times \mathrm{N}$ money units.

The discount factor for the time lag between birth of young bulls and average birth of the offspring in Batch 1 will be $\left(\frac{1}{1+0.10}\right)^{L_{X B}}$, where $L_{Y B}$ is the generation interval for young bulls ( 2 years). Further discounting is necessary for the time interval between birth of the batch and actual expression of genetic superiority. In the example both lactations occur with the same probability $\left(\frac{1}{2}\right)$ and at 2 and 3 years of age,

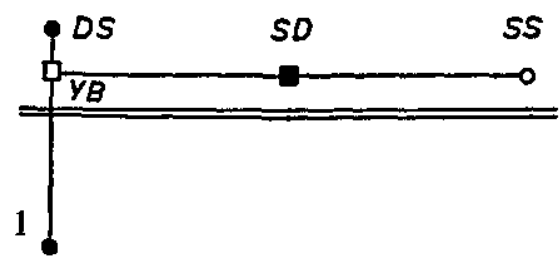

Fig. 2. A batch of first-generation offspring. 


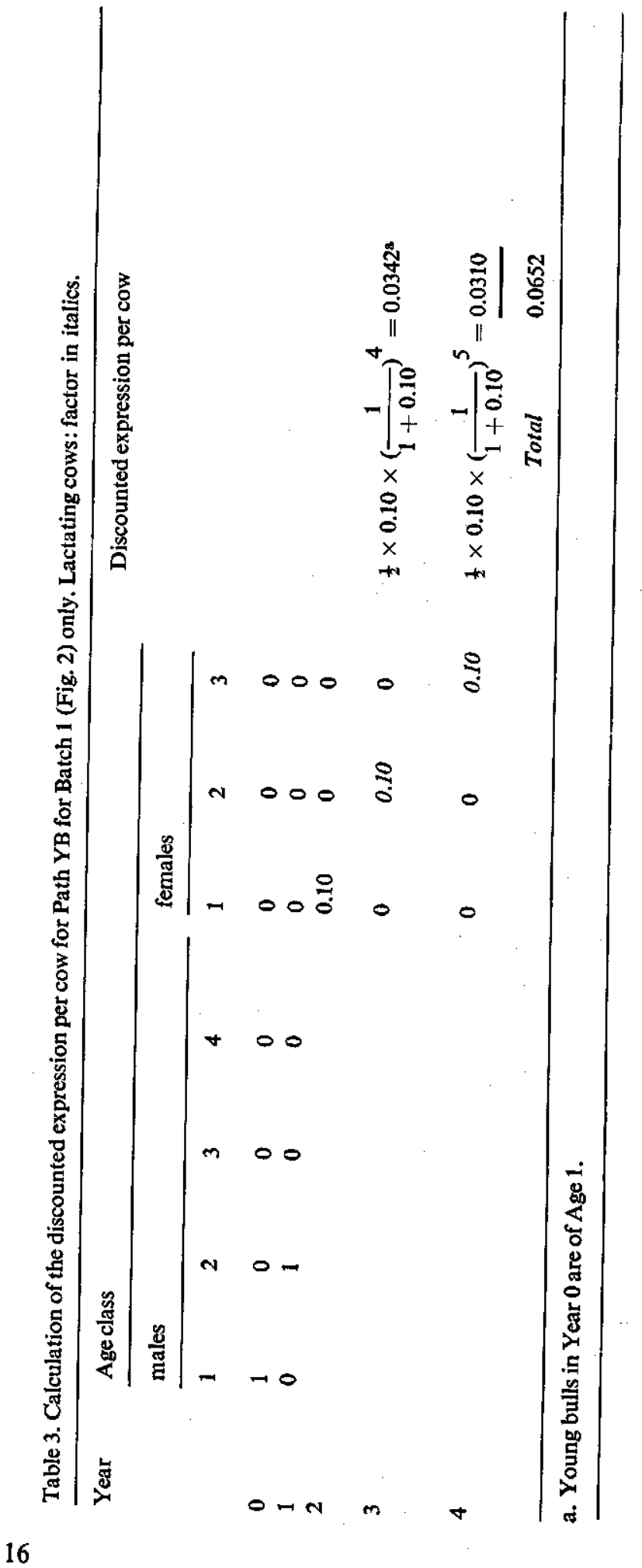


respectively. So the weighted discount factor equals

$$
\frac{1}{2}\left(\frac{1}{1+0.10}\right)^{2}+\frac{1}{2}\left(\frac{1}{1+0.10}\right)^{3}=0.7889 \text {. }
$$

Then the discounted expression per cow, for Batch 1 only, equals

$$
\frac{1}{2} \times(0.2 \times \mathrm{N}) \times\left(\frac{1}{(1+0.10}\right)^{\mathrm{L}_{\mathrm{YB}}} \times 0.7889 / \mathrm{N}=0.0652 .
$$

Monetary values are discounted to the year of birth of the batch of young bulls: the reference year chosen (Paper I; Chapter 2).

In Table 3 the discounted expressions per cow are derived based upon years. Fractions of genes (genetic superiority) in different age classes and years are given, according to Table 2. Fractions for lactating animals in Batch 1 are in italics.

In this case both approaches give identical results.

Case 2 Consider now the third-generation batch of offspring of proven bulls in Fig. 3. This is Batch 3. (It is also one of the batches of third-generation offspring of young bulls.) The number of offspring entering the dairy herd in Batch 1, Fig. 3, is $0.8 \times \mathrm{N} \times \frac{1}{2}$, as proven bulls perform $80 \%$ of the inseminations. Each cow produces on average one replacement heifer, if the population size is constant. So also in Batch 3 the number of offspring entering the dairy herd is $0.8 \times \mathrm{N} \times \frac{1}{2}$, with a total of $0.80 \times \mathrm{N}$ lactations. The genetic relationship between the offspring in Batch 3 and the proven bulls (or young bulls) is $\frac{1}{8}$. The time interval between birth of young bulls (reference year) and average birth of offspring in Batch 3 is $\mathrm{LSD}_{\mathrm{SD}}+2 \mathrm{~L}_{\mathrm{DD}}=4+$ $2 \times 2 \frac{1}{2}=9$ years. $L_{S D}$ and $L_{D D}$ are generation lengths for Paths SD and DD, respectively. So the discounted expression per cow, for Batch 3 only, becomes

$$
\frac{1}{8} \times(0.80 \times \mathrm{N}) \times\left(\frac{1}{1+0.10}\right)^{\mathrm{L}_{\mathrm{SD}}+2 \mathrm{~L}_{\mathrm{DD}}} \times 0.7889 / \mathrm{N}=0.0335 .
$$

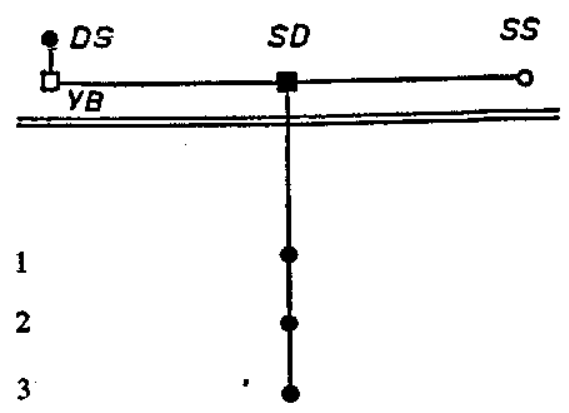

Fig. 3. A batch of third-generation offspring. 


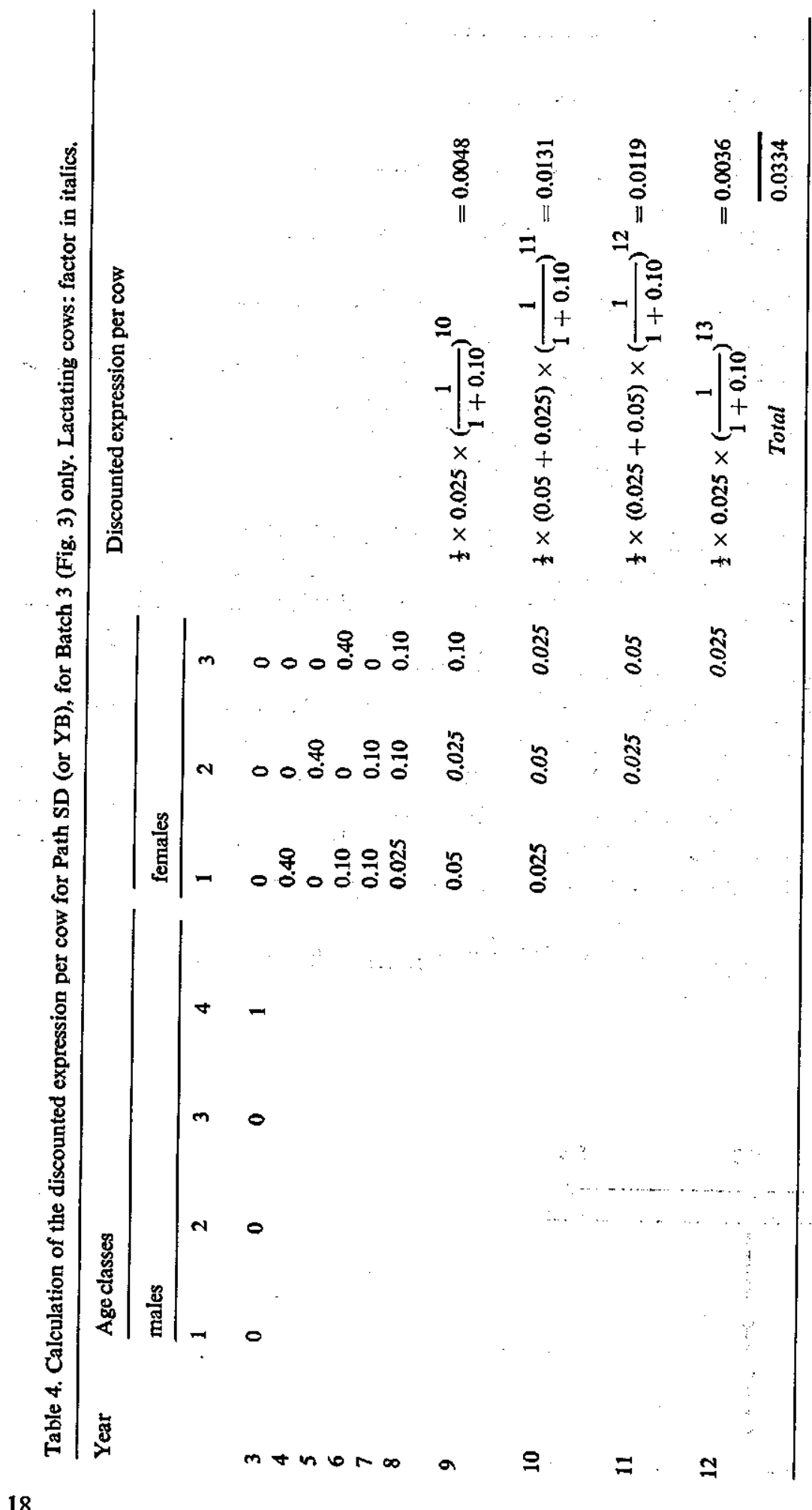


In Table 4 the discounted expressions per cow based upon years are derived. Table 4 is an extension of Table 2.

In Case 2 both approaches have a slightly different outcome. This is caused by the assumption in the generation approach that the lactations per cow are equally divided over Years 10 and 11. In 'reality' the cows lactate in Years 9, 10, 11 and 12. In the more realistic situation of many lactations (Appendix 2) the difference between the set of years in which the cows actually lactate and the years of lactation assumed in the generation approach will be larger, especially in later generations.

Two other differences between the generation approach and the year approach will be explained below.

Assume that four generations of offspring (Fig. 1) cover a period of 25 years. Then some animals included in the generation approach will not have completed all their lactations within 25 years. Other animals in later generations, on the contrary, will have started lactation before Year 25. These effects will balance each other to some extent.

The average generation interval varies by varying $y$. In other words, when $y$ increases, the number of offspring in Fig. 1 resulting from young-bull inseminations will increase. This offspring is born earlier than offspring resulting from proven-bull inseminations. Thus when $y$ increases, the number of years which covers four generations will decrease. This effect will cause a bias in the outcome of the generation approach compared with that of the year approach with a fixed number of years. This effect will be quantified below.

The average generation interval is between 5.1 and 5.9 years depending on $\mathrm{y}$. (Paper I, Appendix 1). On average cows have $3 \frac{1}{3}$ lactations. So four generations can be expected to cover a period of about 24 to 28 years. To compare results from the generation and year approach, 25 years are taken.

\subsubsection{Discounted expressions per cow for milk traits (Paper I)}

The reason for the differences in discounted expressions for milk traits calculated on a generation basis or on a year basis are shown in Table 5. As discussed the number of years which covers four generations decreases when the proportion of insemina-

Table 5. The year in which the cumulative discounted expressions per cow for milk traits calculated on a year basis equal those calculated on a four-generation basis. Interest rate $=10 \%$.

\begin{tabular}{lllllll}
\hline Path & \multicolumn{5}{l}{ Proportion of dual-purpose inseminations with young bulls } \\
\cline { 2 - 7 } & 0.10 & 0.20 & 0.30 & 0.50 & 0.70 & 0.90 \\
& 30 & 29 & 29 & 28 & 27 & 25 \\
SS & 27 & 27 & 26 & 26 & 25 & 25 \\
SD & 28 & 27 & 27 & 26 & 24 & 23 \\
DS and YB & & & & \\
\hline
\end{tabular}


Table 6. Discounted expressions per cow for milk traits based upon 4 generations (a) and upon 25 years (b), relative to Path SS, $y=0.90$. Interest rate is $10 \%$.

\begin{tabular}{rcccccc}
\hline $\begin{array}{l}\text { Path and } \\
\text { method }\end{array}$ & \multicolumn{6}{c}{ Proportion of dual-purpose inseminations with young bulls } \\
\cline { 2 - 7 } SS & 0.10 & 0.20 & 0.30 & 0.50 & 0.70 & 0.90 \\
a & 73 & 76 & 79 & 85 & 92 & 100 \\
b & 63 & 67 & 71 & 79 & 89 & 100 \\
SD & & & & & & \\
a & 206 & 188 & 169 & 129 & 84 & 30 \\
b & 204 & 186 & 168 & 130 & 85 & 31 \\
DS & & & & & & \\
a & 153 & 159 & 165 & 179 & 194 & 212 \\
b & 147 & 155 & 162 & 179 & 199 & 223 \\
\hline
\end{tabular}

Table 7. Bias (\%) in estimates of discounted expressions per cow for milk traits on a 4-generations basis relative to the (cumulative) discounted expressions per cow in Year 25.

\begin{tabular}{lccccccc}
\hline Path & \multicolumn{6}{c}{ Proportion of dual-purpose inseminations with young bulls } \\
\cline { 2 - 7 } & 0.10 & 0.20 & 0.30 & 0.50 & 0.70 & 0.90 \\
SS & +18 & +15 & +13 & +9 & +5 & +1 \\
SD & +2 & +2 & +2 & +1 & +0 & -0 \\
DS and YB & +5 & +4 & +3 & +1 & -1 & -3 \\
\hline
\end{tabular}

tions with young bulls increases.

The discounted expression for Path SS with $y=0.90$, equals 0.1036 on a fourgeneration basis and 0.1022 on a 25 -year basis. In Table 6 discounted expressions are given relative to Path SS, y $=0.90$, both based on four generations and on 25 years. When y decreases the discounted expressions for all paths on 25 years decrease compared to those based on four generations.

The size of this tendency and the size of difference between discounted expressions based on both methods is different for each path, which can also be seen clearly in Table 7. In this table the deviations in estimates of discounted expressions based upon four generations from those based on 25 years are given relative to the estimates based on 25 years. These effects, common to Tables 5 to 7 , can be explained as follows. The tendency common to all paths was explained before: the average generation interval decreases when $y$ increases because of the balance between the number of offspring from young-bull inseminations and the number of offspring from proven-bull inseminations. For Path SD the effect of this balance first occurs in the third generation (see Fig. 1). The female offspring in the first and second generation account for a 
Table 8. Weighing of paths in $\Delta \mathrm{G}$, relative to Path $\mathrm{SS}, \mathrm{y}=\mathbf{0 . 9 0}$.

\begin{tabular}{lllllll}
\hline Path & \multicolumn{6}{l}{ Proportion of dual-purpose inseminations with young bulls } \\
\cline { 2 - 7 } & 0.10 & 0.20 & 0.30 & 0.50 & 0.70 & 0.90 \\
SS & 86 & 88 & 89 & 93 & 96 & 100 \\
SD & 78 & 70 & 63 & 46 & 29 & 10 \\
DS & 86 & 88 & 89 & 93 & 96 & 100 \\
\hline
\end{tabular}

large part of the (cumulative) discounted expression for Path SD. For the first and second generation the difference in discounted expressions calculated by both methods is small, as illustrated in the previous example.

For Path SS on the contrary, the first female offspring is obtained in the second generation. The years in which this offspring produces is influenced by $y$, and with that the number of years covering four generations. So the effect of $y$ for Path SS will be larger than for Path SD.

As seen in Fig. 1 all batches of female offspring contribute to discounted expressions for Path YB and DS.

The first female offspring via these paths is first-generation progeny, both from young-bull inseminations and from proven-bull inseminations. So the effect of $y$ will be larger for these paths, just as for SS.

The four generations offspring of young-bull inseminations of parent group YB in Fig. 1 cover the fewest years: the four generations offspring of parent group SS the most. This fact explains the differences in outcomes for different paths at a certain $y$ given in Table 5 and related effects in Tables 6 and 7.

A conclusion in Paper I was that the discount factor for the time lag increases as the number of doses per bull increases. This conclusion has important consequences for the calculation of returns from breeding plans. The conclusion follows from the higher contribution of Path SD to returns than to genetic improvement while for Path SS the opposite is true. Table 8 shows the weighing of paths in $\Delta G$. Tables 6 and 8 show that the increase in discount factor at increasing number of doses holds irrespective of calculation of discounted expressions per cow: based upon four generations or on 25 years.

\subsubsection{Discounted expressions per cow for meat traits (Paper III)}

Table 9 shows the number of years for which the (cumulative) discounted expressions based on years equal those based on four generations dependent on $y$, the proportion of dual-purpose inseminations with young bulls, and on $k$, the proportion of beef crossing. The difference between years in Table 9 and comparable data in Table 5 is about 5 . This difference arises because discounted expressions for meat are calculated at the birth of calves (see Appendix 3) and because animals express their genetic superiority for milk at about five years of age in average. 
Table 9. The year in which the cumulative discounted expressions per cow for meat traits calculated on a year basis equal those calculated on a four-generation basis. Interest rate $=10 \% . y$ is the proportion of dual-purpose inseminations with young bulls. $k$ is the proportion of beef crossing.

\begin{tabular}{|c|c|c|c|c|c|c|c|c|c|}
\hline \multirow[t]{2}{*}{$\mathbf{y}$} & \multicolumn{3}{|l|}{ Path SS } & \multicolumn{3}{|l|}{ Path SD } & \multicolumn{3}{|c|}{ Path YB (or DS) } \\
\hline & $k=0.0$ & $\mathrm{k}=0.1$ & $\mathrm{k}=0.2$ & $k=0.0$ & $\mathrm{k}=0.1$ & $\mathrm{k}=0.2$ & $\mathrm{k}=0.0$ & $k=0.1$ & $\mathrm{k}=0.2$ \\
\hline 0.10 & 25 & 25 & 25 & 22 & 22 & 21 & 23 & 23 & 23 \\
\hline 0.20 & 25 & 25 & 24 & 22 & 21 & 21 & 23 & 22 & 22 \\
\hline 0.30 & 24 & 24 & 24 & 21 & 21 & 21 & 22 & 22 & 22 \\
\hline 0.50 & 23 & 23 & 23 & 21 & 21 & 20 & 21 & 21 & 20 \\
\hline 0.70 & 22 & 22 & 22 & 20 & 20 & 20 & 20 & 19 & 19 \\
\hline 0.90 & 21 & 21 & 21 & 20 & 20 & 20 & 18 & 18 & 18 \\
\hline
\end{tabular}

Table 10. The ratios between discounted expressions per cow for milk traits and for meat traits. Period considered 25 years, interest rate $=10 \% . \mathrm{y}$ is the proportion of dual-purpose inseminations with young bulls. $\mathrm{k}$ is the proportion of beef crossing.

\begin{tabular}{|c|c|c|c|c|c|c|}
\hline \multirow[t]{2}{*}{ y } & \multicolumn{2}{|l|}{ Path SS } & \multicolumn{2}{|l|}{ Path SD } & \multicolumn{2}{|l|}{ Path YB } \\
\hline & $\mathrm{k}=\mathbf{0 . 0}$ & $\mathrm{k}=0.2$ & $\mathrm{k}=0.0$ & $\mathrm{k}=0.2$ & $k=0.0$ & $\mathrm{k}=\mathbf{0 . 2}$ \\
\hline 0.10 & 0.847 & 1.082 & 0.960 & 1.213 & 0.917 & 1.160 \\
\hline 0.50 & 0.841 & 1.072 & 1.052 & 1.331 & 0.904 & 1.143 \\
\hline 0.90 & 0.868 & 1.106 & 1.184 & 1.493 & 0.926 & 1.170 \\
\hline
\end{tabular}

The ratios between discounted expressions for milk traits and those for meat traits both based on 25 years are given in Table 10 . The actual ratios will be slightly higher, dependent on slaughter age of beef animals.

The ratios based on 25 years given in Table 10 will be lower than on a four-generation basis (Paper III), as follows from Tables 5 and 9. The ratios for Paths SD, DS and YB based on 25 years are approximately $7 \%$ lower than when based on four generations. For Path SS this is $13 \%$. The conclusions in Paper III (see Chapter 2) about tendencies in the ratio between discounted expressions per cow for milk and meat traits are not affected by the method of calculating discounted expressions.

\subsubsection{Optimum breeding plans for milk traits (Paper II)}

For management system A (deep-frozen semen storage) net returns for breeding plans are recalculated with discounted expressions based on 25 years. In Paper II the calculations were based on the four-generations approach. Cost alternatives 1 and 7 were studied (see Table 1). Main conclusions from Paper II are still valid. Some minor changes, however, warrant further discussion.

Optimum and suboptimum breeding schemes based upon four generations were characterized by a high number of doses stored per bull (e.g. for a population size of 
400000 and a production of 25000 doses per bull per year the optimum number of doses stored per bull was 135000 ). Further these schemes are characterized by a progeny group size exceeding 100 with y between 0.20 and 0.30 . For cost alternatives with relatively high costs of semen production and storage, suboptimum schemes were characterized by a low number of doses per bull $(3000-10000)$. See Fig. 1, Paper II. For these schemes the proportion of inseminations with young bulls was high $(y=0.90)$.

Compared to the 25-year approach, discounted expressions based on four generations for all paths are overestimated when $\mathrm{y}$ is low and underestimated when $\mathrm{y}$ is high. The situation will be the same for returns. This explains why on a 25 -year basis $y$ is higher than on a four-generation basis for optimum and suboptimum schemes. The order of size of this change in optimum $y$ is $\mathbf{0 . 1 0}$.

Also the difference in net returns between optimum schemes with low y (and a high number of doses stored), and schemes with high y (and a low number of doses stored) will be somewhat smaller when returns are calculated on a 25 -year basis compared with the four-generations approach. For the alternatives studied this difference remained positive.

Suboptimum schemes for Cost alternative 7 (below a certain cost level) are characterized by low number of doses per bull, both when returns are calculated over four generations or over 25 years. When calculations of returns are based on 25 years, suboptimum schemes with high y and a low number of doses stored will be found at cost levels where the four-generations approach gives suboptimum schemes with low $y$ and a high number of doses stored. Compare Fig. 1, Paper II. 


\section{General discussion}

- Fig. 1 shows the structure of the evaluation of returns from a breeding scheme. The position of Path DS in this figure has been discussed in Paper I. The position of Path SS and, connected with that, the question which costs account for which returns, warrant further discussion.

In a breeding programme the first step is the purchase of a batch of young bulls. Returns are evaluated from genetic superiority expressed in progeny of this batch of young bulls. Path DS is represented by the dams of this batch, Path SD and SS are represented by bulls selected from the batch. Costs for the breeding scheme are costs associated with the batch of young bulls: selection of bull dams, purchase of bulls, sperm production, progeny testing etc. So proven bulls, including bull sires, can not be obtained without incurring all costs (except for bull dam selection) for the scheme. For the selection of bull dams, however, only milk recording is needed.

In this setup net returns (returns minus costs) from a breeding scheme (associated with one batch of young bulls) are the same whether the breeding scheme is in an initial stage or whether it has been in operation for a long time. However, if a breeding scheme has been in operation for many years, it may be tempting to consider the sires of a batch of young bulls as Path SS (i.e. the position of Path SS is then the same as the position of Path DS in Fig. 1). So return calculations will give very different results, as the discounted expressions per cow for Path SS then equal those for Path DS. However costs of an earlier batch of young bulls should also be considered and costs associated with one batch of young bulls should be allotted to Path SS or SD. This distribution of costs is unrealistic because selection of proven bulls including

Table 11. Time period considered and interest rate adopted.

\begin{tabular}{lll}
\hline Authors & Period & $\begin{array}{l}\text { Interest rate } \\
(\%)\end{array}$ \\
Lindhé (1968) & $\infty$ & 10 \\
Hinks (1971) & 2 generations & 8 \\
Hill (1971) & 20 years & $8.15 ; 20$ \\
McClintock \& Cunningham (1972) & 15 years & 8 \\
Niebel (1974) & 25 years & 8 \\
Peterson et al. (1974) & $\infty$ & 10 \\
\hline
\end{tabular}

1. These authors evaluate returns from 10 years of progeny of proven bulls. This period covers about 15 years of progeny of young bulls. 
bull sires is part of one operation.

- In calculating discounted expressions per cow or monetary returns four generations of offspring of selected parents were included. In the previous sections calculations were based upon 25 years. An interest rate of $10 \%$ was used. In Table 11 the period considered and the interest rate adopted by different authors are given. The infinite number of years considered by Lindhé (1968) followed from his criterion to detect an optimum breeding scheme (see Paper I, discussion). Peterson et al. (1974) used the same criterion. An argument against taking a lot of years or generations is the uncertainty of future returns (McClintock \& Cunningham, 1972). This uncertainty is also noted by Poutous \& Vissac (1962). One way to cope with this uncertainty is by adopting a higher interest rate (Lindhé, 1968).

In the literature, and also in this thesis, the nominal interest rate (e.g. for mortgage loans) has always been chosen. Returns from breeding schemes are obtained over a long period. During this period, in many countries the net milk price will follow the rate of inflation. So interest rates might be adopted excluding inflation. ${ }^{1}$ This real interest rate is about 2 to $3 \%$.

When an interest rate for the evaluation of returns from breeding schemes is chosen, the following should be considered:

1. What is the real interest rate?

2. To what extent will the net value of products (e.g. milk) follow the inflation rate?

3. How can uncertainty in predictions of future returns be dealt with?

The real interest rate can be seen as a basic interest rate. The other two considerations will modify the basic interest rate.

Probably the net value of products will not quite follow the inflation rate. Or, if inflation is zero, the net value of one unit of product tends to decrease because more efficient production, e.g. by better organization or technical improvement, tends to result in smaller margins. Uncertainty, for instance caused by change in preference of the consumer, in predictions of future returns is smaller for returns early in time than for later returns. So this uncertainty can better be dealt with by choosing a higher interest rate than by adopting a constant loss factor.

The effects of choice of interest rate and time period are shown in Table 12 for discounted expressions per cow for milk traits. Returns calculated with an interest rate of $5 \%$, including 25 years, are roughly twice as high as with an interest rate of $10 \%$. A zero interest rate leads to values about four times as high (Table 12). The influence of time period considered on discounted expressions depends both on path and interest rate. For example, if we consider only 10 years, Path SS hardly contributes to returns, whereas via Paths SD, DS and YB 30 to $50 \%$ of returns via these paths are attained in this period compared with 25 years (interest rate $10 \%$ ). Further examination of Table 12 shows substantial increase of discounted expressions from 25 to 50 years, especially for Path SS, even at the interest rate of $10 \%$.

Returns from breeding schemes over 10,15,20 and 50 years in addition to those over

1. This argument was brought to my attention by Dr J. H. Renkema. 
Table 12. Relative discounted expression per cow influenced by the number of years considered and interest rate $\mathrm{r}(\%)$. Discounted expressions are given relative to classes with 100 (underlined).

Proportion of inseminations with young bulls is $10 \%$

\begin{tabular}{|c|c|c|c|c|c|c|c|c|c|c|c|c|}
\hline \multirow[t]{3}{*}{ Years } & \multicolumn{4}{|c|}{ Path SS } & \multicolumn{4}{|c|}{ Path SD } & \multicolumn{4}{|c|}{ Path DS or YB } \\
\hline & $\mathbf{r}=$ & & & & $\mathbf{r}=$ & & & & $\mathrm{r}=$ & & & \\
\hline & 0 & 5 & 10 & 15 & 0 & 5 & 10 & 15 & 0 & 5 & 10 & 15 \\
\hline 10 & $\sim 0$ & $\sim 0$ & $\sim 0$ & $\sim 0$ & 99 & 61 & 39 & 26 & 81 & 52 & 34 & 22 \\
\hline 15 & 67 & 33 & 17 & 9 & 231 & 131 & 77 & 47 & 192 & 109 & 65 & 40 \\
\hline 20 & 360 & 153 & 69 & 32 & 316 & 166 & 92 & 53 & 319 & 161 & 87 & 50 \\
\hline 25 & 653 & 247 & 100 & 43 & 392 & 190 & 100 & 56 & 439 & 200 & 100 & 54 \\
\hline 50 & 2044 & 472 & 144 & 53 & 788 & 254 & $\overline{113}$ & 59 & 1034 & 296 & $\overline{119}$ & 59 \\
\hline \multicolumn{13}{|c|}{ Proportion of inseminations with young bulls is $90 \%$} \\
\hline \multirow[t]{3}{*}{ Years } & \multicolumn{4}{|c|}{ Path SS } & \multicolumn{4}{|c|}{ Path SD } & \multicolumn{4}{|c|}{ Path DS or YB } \\
\hline & $r=$ & & & & $\mathbf{r}=$ & & & & $\mathrm{r}=$ & & & \\
\hline & 0 & 5 & 10 & 15 & 0 & 5 & 10 & 15 & 0 & 5 & 10 & 15 \\
\hline 10 & 3 & 2 & 1 & 1 & 93 & 58 & 37 & 24 & 99 & 68 & 49 & 36 \\
\hline 15 & 166 & 86 & 46 & 26 & 221 & 125 & 73 & 44 & 191 & 117 & 75 & 50 \\
\hline 20 & 358 & 164 & 79 & 40 & 320 & 166 & 91 & 52 & 282 & 153 & 90 & 57 \\
\hline 25 & 553 & 226 & 100 & 48 & 408 & 193 & 100 & 55 & 372 & 182 & 100 & 60 \\
\hline 50 & 1566 & 391 & 133 & 55 & 838 & 263 & 114 & 59 & 827 & 256 & 115 & 64 \\
\hline
\end{tabular}

25 years have been calculated for the same alternatives as in Section 3.2 (interest rate $10 \%$ ). Calculation of returns over 20 and 50 years gives a ranking of breeding schemes with respect to returns very similar to the ranking at 25 years. For 10 and 15 years the optimum cost level is lower than for 25 years, while for Cost alternative 7 with calculation of returns over 10 and 15 years, optimum schemes were characterized by low number of doses stored per bull. This finding is similar to the conclusion for suboptimum schemes when 25 years are considered (Section 3.2).

- Uncertainty of costs for a breeding scheme can not be compensated for in the same way as that of returns. Most costs for a breeding plan are incurred before there are any returns and also the period over which returns are to be expected is much longer than that of investment. In Paper II, the effect of variation in cost factors on the optimum breeding plan was studied. This analysis covered the actual situations in different $\mathrm{AI}$ organizations or countries, but at the same time revealed the sensitivity of the model for changes in costs.

- Calculation of discounted expressions and of returns is based upon a fixed population structure. Dissemination of genes, however, may be influenced by the breeding value of individual bulls or may change for other reasons. Also the population size 
may change with time (see Paper I). Further, predictions of genetic superiority and selection responses are expectations. Deviations by chance of individual bulls from the expectation may influence the intensity of their use and the dissemination of their genes. Also the average breeding value of a group of parents generally will differ from the expectation. Part of these effects can be met by applying Monte-Carlo methods (e.g. Simon, 1969).

Many replicates of each breeding programme should be run and the average resulh will probably not differ much from deterministic-model approaches. It gives, however, insight into the range of predictions, and further into the distribution of returns around the expectation.

A related problem is: how large a difference between net returns of two breeding programmes is a 'real' difference. To answer this question the standard deviation of predictions, obtained by Monte-Carlo methods, can be applied. On the other hand it may be argued that if one scheme has higher net returns than another, the probability of actually attaining higher net returns is over $50 \%$; this makes the scheme with highest net returns the most worthwhile choice. However, distribution of returns possibly is not symmetric, and the range of predictions may be different from one breeding scheme to another. 


\section{Summary}

The effect of costs for AI breeding on the optimum breeding plan for milk yield and the profitability of performance-test selection for meat traits within a dual-purpose breed of cattle were studied in three papers. Methods and results given in these papers are summarized in Chapter 2.

Returns from breeding schemes were calculated with a generation approach, i.e. the expression of genetic improvement in subsequent generations was the basis for the estimation of returns. An interest rate of $10 \%$ was adopted.

The method of Hill (1974) was used to calculate returns with a year approach in which the expression of genetic improvement in subsequent years was the basis. Both methods were compared by calculation of discounted expressions per cow, for different pathways, over 4 generations with the generation approach and over 25 years with the year approach. Major conclusions, summarized in Chapter 2, did not change though discounted expressions per cow, and returns too, calculated by either method differed systematically. For Paths SS and DS, but less for SD, discounted expressions per cow were found to be overestimated by the generation approach compared with the outcomes of the year approach when the proportion of inseminations with young bulls (y) was low, and underestimated when y was high (Tables 6,7 and 9).

To study the effects of the interest rate and time period, discounted expressions per cow were calculated for interest rates of 0,5 and $10 \%$, with the year approach. The discounted expressions were calculated over 10, 15, 20, 25 and 50 years (Table 12). At $10 \%$ interest rate ranking of breeding schemes with respect to returns was similar if returns were calculated over 20, 25 or 50 years. Calculating returns over 10 or 15 years, however, resulted in optimum breeding schemes characterized by a lower cost
level. 


\section{Samenvatting}

Het onderzoekterrein van de rundveefokkerij kan opgesplitst gedacht worden in drie deelgebieden. Het eerste deelgebied betreft de definitie van een fokdoel. Er zijn vele kenmerken die van belang zijn, en het definiëren van een fokdoel of samengesteld genotype komt neer op het vinden van relatieve (economische) waarden van kenmerken waarop geselecteerd moet worden. Voor Duitse omstandigheden is dit probleem onderzocht door Niebel et al. (1972). Uit hun resultaten kan geconcludeerd worden dat melkproduktie (en -bestanddelen) benevens groei per dag, dan wel voederconversie, de belangrijkste elementen zijn in het fokdoel.

Het tweede gebied beschouwt de fokwaardeschatting. De analyse en correctie van (veld)gegevens valt hieronder; deze kunnen bijdragen tot een betrouwbare schatting van de fokwaarde van dieren voor kenmerken in het fokdoel.

Het derde gebied heeft als vraagstelling: hoe moet het fokprogramma georganiseerd worden opdat het selectieresultaat voor de populatie zo groot mogelijk wordt. Met runder-k.i. kan een hoog selectieresultaat behaald worden doordat hij een nauwkeurige fokwaardeschatting van stieren mogelijk maakt voor kenmerken die aan de stieren zelf niet te meten zijn. Verder kunnen goed verervende stieren op ruime schaal gebruikt worden.

Het onderwerp van dit proefschrift valt binnen het derde gebied: optimalisatie van fokprogramma's in een populatie met kunstmatige inseminatie. Met andere woorden, welke opzet van het fokprogramma levert een zo groot mogelijk selectieresultaat. De vraagstelling is beperkt tot melkproduktie (en -bestanddelen), terwijl voor vleesproduktiekenmerken een algemene benadering is gevolgd, met een uitwerking voor het kenmerk groei per dag voor Nederlandse kostenverhoudingen. Een fokprogramma heet optimaal wanneer de netto inkomsten uit het fokprogramma maximaal zijn. Het selectieresultaat wordt dus gemeten als netto inkomsten uit het fokprogramma. Netto inkomsten zijn inkomsten minus kosten voor het fokprogramma.

Het proefschrift bestaat uit drie artikelen, en een vergelijking van de daarin gehanteerde methodiek om de geldwaarde van het selectieresultaat te schatten met een methode beschreven door Hill (1974).

Het belangrijkste element in de schattingsmethode van de geldwaarde van het selectieresultaat, in genoemde artikelen, is het aantal nakomelingen van geselecteerde ouderdieren (selectiewegen) in vier opvolgende generaties. Deze nakomelingen erven een deel van de genetische superioriteit van ouderdieren en uiten deze in verbeterde produktie. Zie hiervoor fig. 1 . Als selectiewegen worden beschouwd: SS, stieren om stieren te fokken; stieren om dochters te fokken (proefstieren YB and fokstieren SD) 
alsmede DS, koeien om stieren te fokken. De selectieweg: koeien om dochters te fokken (DD) is buiten beschouwing gelaten voor het berekenen van inkomsten uit fokprogramma's omdat de opzet van het fokprogramma de selectie via deze laatste selectieweg niet beïnvloedt.

Daar nakomelingen van geselecteerde ouders op zeer uiteenlopende momenten produceren, is het nodig van de toekomstige inkomsten de huidige (contante) waarde te berekenen. Als referentiejaar is gekozen het jaar van geboorte van een jaargang proefstieren. Er is een rentevoet van $10 \%$ gehanteerd.

De methode om inkomsten uit selectie op melkproduktie uit een fokprogramma te schatten is beschreven in het eerste artikel. De relatieve bijdrage van de selectiewegen SD en DD aan de inkomsten bleek hoger te zijn dan hun relatieve bijdrage aan de erfelijke vooruitgang per jaar $(\Delta G)$. Voor de selectieweg SS geldt het tegenovergestelde, terwijl voor selectieweg DS (en voor YB) de relatieve bijdrage aan inkomsten en aan $\Delta G$ vrijwel gelijk was. $\Delta G$ werd berekend met de formule van Rendel \& Robertson (1950).

Om de relatie te leggen tussen inkomsten en $\Delta \mathrm{G}$, werd een contante-waardefactor (DF) gedefinieerd. Deze contante-waardefactor is de verhouding tussen de inkomsten uit een fokprogramma en de inkomsten berekend als een lineaire functie van $\Delta G$. DF kan geïnterpreteerd worden als de contante-waardefactor voor de tijdsperiode die ligt tussen de geboorte van een jaargang proefstieren en het tijdstip waarop inkomsten tot stand komen voorvloeiend uit selectie van moeders van die proefstieren, en uit selectie van fokstieren en stiervaders uit de jaargang proefstieren. DF varieerde van 0,28 tot 0,40 , wat betekent dat genoemde tijdsperiode ligt tussen circa 9 en 13 jaar. De belangrijkste invloedsfactor op DF bleek te zijn het aantal inseminaties dat verricht wordt per fokstier (d.i. het antal doses dat per stier verzameld wordt). Voor 3000 doses per stier varieerde DF van 0,28 tot 0,30 en voor 80000 doses per stier van 0,38 tot 0,40 . Andere invloedsfactoren (bij een vaste rentevoet) bleken het aandeel der eerste inseminaties dat verricht wordt met zaad van fokstieren, en de grootte der nakomelingengroepen. Gerekend werd met een populatiegrootte van 400000 koeien.

In het tweede artikel werd de invloed nagegaan van kostenfactoren op het optimale fokprogramma (voor selectie op melkproduktie). Er werden 12 kostenalternatieven gekozen (tabel 2) met uiteenlopende verhoudingen tussen kostenfactoren als kosten voor sperma-opslag en kosten voor voer.

Twee systemen zijn vergeleken, te weten het Proefstier-Wachtstier-Fokstier(PWF)systeem, (B), zonder opslag van diepvriessperma gedurende de wachtperiode, en het systeem waarbij stieren worden geslacht zodra een vooraf bepaald aantal doses sperma per stier zijn opgeslagen, (A). Het invriezen van sperma onder Systeem A start meteen nadat proefinseminaties verricht zijn.

De populatiegrootte werd gevarieerd van 50000 tot 1 miljoen eerste inseminaties. Verder werd het aandeel der inseminaties verricht met zaad van proefstieren $(y)$ gevarieerd van 0,10 tot 0,90 , en de grootte der nakomelingengroepen van 50 tot 600 . 
Het aantal doses per stier werd gevarieerd van 3000 tot 220000 en de dosesproduktie per stier per jaar van 15000 tot 35000 .

Voor alle beschouwde kostenalternatieven bleek Systeem A economisch aantrekkelijker dan Systeem B. Optimale fokprogramma's onder Systeem A werden gekarakteriseerd door opslag van een groot aantal doses per stier. (B.v. in een populatie van 400000 koeien en een spermaproduktie van 25000 doses per stier per jaar, bleek een opslag van 135000 doses per stier optimaal). Verder bleek de optimale waarde voor y te liggen tussen 0,20 en 0,30 en de optimale grootte van de nakomelingengroep boven de 100.

Een optimaal fokprogramma is een programma met het grootste verschil tussen inkomsten en kosten. Om echter situaties te dekken waarin men niet bereid is de bij het optimale fokprogramma behorende kosten te investeren, werden tevens suboptimale fokprogramma's gedefinieerd. Dit zijn fokprogramma's met de hoogste netto inkomsten bij een bepaald kostenniveau. Over het algemeen hadden suboptimale fokprogramma's dezelfde karakteristieke kenmerken als optimale. Uitzonderingen werden echter gevonden voor kostenalternatieven met hoge kosten voor spermaproduktie en opslag, en lage kosten voor voer (alternatieven 4, 7 en 10, tabel 2). In die gevallen bleek bij lage kostenniveau's Systeem B economisch aantrekkelijker dan Systeem A. Onder Systeem A werden dan suboptimale programma's gevonden bij een laag aantal doses per stier en een hoog aandeel der inseminaties met zaad van proefstieren.

Netto inkomsten uit optimale en suboptimale fokprogramma's stegen met de populatiegrootte. In het model was de grootte van kostenfactoren echter onafhankelijk van de populatiegrootte, zodat een optimale populatiegrootte niet kon worden vastgesteld.

Het derde artikel handelt over de rentabiliteit van eigen-prestatietoets op vleesproduktiekenmerken. Behalve de optimale selectiescherpte na eigen-prestatietoets, werd de optimale weging van melk- en vleesproduktiekenmerken in het samengesteld genotype bestudeerd. Daartoe werd het begrip 'discounted expression per cow', 'contante waarde per koe', geïntroduceerd. De contante waarde per koe voor kenmerk i en selectieweg $\mathrm{j}$ is gedefinieerd als de naar huidige waarde berekende inkomsten voortvloeiend uit verhoogde produktie voor kenmerk i van nakomelingen van ouders (selectieweg j) met een genetische superioriteit van én eenheid, gedeeld door de populatiegrootte. (Stel bijvoorbeeld dat voor het kenmerk melkproduktie voor fokstieren een contante waarde per koe geldt van 0,2 ; dit betekent dat inzet van fokstieren met een genetische superioriteit van $f 100,-$ een totale opbrengst uit verhoogde melkproduktie van nakomelingen oplevert van $\mathrm{f} 20,-$ ).

Verder is de invloed van gebruikskruising met vleesrassen op de rentabiliteit van eigen-prestatietoets en op de weging van melk en vlees in het samengesteld genotype onderzocht. De belangrijkste conclusies kunnen als volgt worden samengevat. De rentabiliteit van de eigen-prestatietoets hangt voornamelijk af van de selectiescherpte van stiermoeders, de relatieve economische waarde van melk- en vleesproduktiekenmerken, de kosten, en van het aandeel gebruikskruisingen. De optimale geselec- 
teerde fractie na eigen-prestatietoets ligt over het algemeen tussen 1 op 2 en 1 op 4 . Over het algemeen neemt de rentabiliteit van eigen-prestatietoets af bij toename van het aandeel gebruikskruising. De optimale weging van melk- en vleesproduktiekenmerken in het samengesteld genotype is het produkt van hun actuele economische waarde en de bijbehorende contante waarde per koe. Deze weging verschilt per selectieweg en de nadruk op de kenmerken verschuift naar melkproduktiekenmerken bij een toenemend aandeel gebruikskruising (tabel 10).

Contante waarden per koe werden tevens geschat met behulp van de methode van Hill (1974). In de drie tijdschriftartikelen berustten de berekeningen op het aantal nakomelingen van geselecteerde ouders in vier opvolgende generaties. Toepassing en uitbreiding van de door Hill (1974) beschreven methode maakt het mogelijk contante waarden per koe (en inkomsten uit fokprogramma's) te schatten op basis van het aantal nakomelingen van geselecteerde ouders in een opvolgend antal jaren. De methodes zijn vergeleken door de inkomsten over 25 jaar te evalueren.

De conclusies van de artikelen bleken niet beïnvloed te worden door de keuze van methode: op basis van generaties of op basis van jaren. Wel vertoonden de twee methodes systematische verschillen in de contante waarden per koe. Speciaal voor de selectiewegen SS en DS, en in mindere mate voor SD, bleken de contante waarden per koe op basis van de generatiemethode overschat te zijn ten opzichte van de uitkomst van de jaarmethode, tenminste als het aandeel van de inseminaties met zaad van proefstieren laag was. Was dit aandeel hoog, dan bleken de contante waarden onderschat.

Met gebruikmaking van de jaarmethode is bestudeerd wat de invloed is van de keuze van de rentevoet en van de periode waarover men inkomsten evalueert op contante waarden per koe en op inkomsten. Bij een periode van 25 jaar zijn de contante waarden per koe bij een rentevoet van $0 \%$, vergeleken met de uitkomst bij een rentevoet van $10 \%$, globaal vier maal zo hoog. De invloed van de beschouwde periode op de contante waarde per koe verschilde per selectieweg. Bij een periode van 10 jaar bijvoorbeeld, bleek de selectieweg SS nauwelijks bij te dragen aan de inkomsten, terwijl de inkomsten via de selectiewegen SD, DS en YB voor elke weg $30-50 \%$ bedroegen van hetgeen in 25 jaar kon worden verkregen (rentevoet $10 \%$, tabel 12). Keuze van een periode van 20,25 of 50 jaar heeft nauwelijks invloed op de rangorde van fokprogramma's op basis van netto inkomsten, terwijl voor een kortere periode programma's met een lager kostenniveau optimaal zijn. 


\section{References $^{1}$}

Bech Andersen, B. \& E. Ernst, 1972. Ergebnisse von Ultraschallmessungen an Jungbullen. Züchtungskunde 44: 81-90.

Bichard, M., 1971. Dissemination of genetic improvement through a livestock industry. Anim. Prod. 13: 209-218.

Boer, H. de, 1973. Working party on Assessment of carcass characteristics in cattle. 24th ann. meeting of EAAP, Vienna.

Brascamp, E. W. \& D. Minkema, 1972. Economic aspects of selection for milk, fat-\% and protein-\% in a dairy cow Al population. Z. Tierz. Züchtungsbiol. 89: 99-108.

Cochran, W. G., 1951. Improvement by means of selection. Proc. 2nd Berkeley Symp. on Mathematics, Statistics and Probability. University of California Press, p. 449-470.

Cunningham, E. P. \& A. E. McClintock, 1972. Selection in dual-purpose cattle populations: Effect of beef crossing and cow replacement rates. Submitted to Ann. Génét. Sél. Anim. (Ann. Génét. Sél. Anim. (1974) 6 : 227-239).

Gravert, H. O. \& E. Rosenhahn, 1965. Welche Kriterien sind wirtschaftlich wichtig. Züchtungskunde 37:244-250.

Haring, H. J. F., 1972. Die Zuchtplanung in der Rinderzucht am ökonomischer Sicht. Diss. Göttingen.

Hill, W. G., 1971. Investment appraisal for national breeding programmes. Anim. Prod. 13: 37-50.

Hill, W. G., 1974. Prediction and evaluation of response to selection with overlapping generations. Anim. Prod. 18: 117-140.

Hinks, C. J. M., 1970. The selection of dairy bulls for artificial insemination. Anim. Prod. 12: 569576.

Hinks, C. J. M., 1971. The genetic and financial consequences of selection amongst dairy bulls in artificial insemination. Anim. Prod. 13: 209-218.

Knaack, J., H. Nehring \& G. Lorenz, 1973. Neue Ergebnisse der experimentellen willkürlichen Geschlechtsbeeinflussung beim Rind. Tierzucht 27: 156-159.

Lindström, U., 1971. Some points of view on the estimation and importance of genetic change in populations of dairy cattle. Ann. Génét. Sél. Anim. 3: 161-168.

Lindhé, B., 1968. Model simulation of Al breeding within a dual purpose breed of cattle. Acta Agric. scand. 18: 33-41.

Mason, I. L., V. E. Vial \& R. Thompson, 1972. Genetic parameters of beef characters and the genetic relationship between meat and milk production in British Friesian cattle. Anim. Prod. 14: 135-148.

McClintock, A. E. \& E. P. Cunningham, 1972. Selection in dual purpose cattle populations: Defining the breeding objective. Submitted to Anim. Prod. (Anim. Prod. (1974) 18:237-247).

Niebel, E., 1974. Methodik der Zuchtplanung für die Reinzucht beim Rind bei Optimierung nach Zuchtfortschritt und Züchtungsgewinn. Diss. Hohenheim.

Niebel, E. \& D. Fewson, 1971. Methodik der Zuchtplanung für die Reinzucht beim Rind. LH Hohenheim; Inst. f. Tierzucht.

Niebel, E., A. Rittler \& D. Fewson, 1972. Die Leistungsmerkmale beim Rind. Teil B: Selektionswürdigkeit der Leistungsmerkmale. Stuttgart, Ulmer.

1. Includes the references of the papers. 
Oscarsson, G., 1968. Mjølk- og kjøttproduksjonen i 1970-åra. Produksjonsutvecklingen. Buskap og Avdrătt 2: 175-179.

Oscarsson, G. \& B. Lindhé, 1970. Spermakostnader i seminverksamheten. SHS Meddelande 36.

Petersen, P. H., L. G. Christensen, B. Bech Andersen \& E. Ovesen, 1974. Economic optimisation of the breeding structure within a dual-purpose cattle population. Acta Agric. scand. 24: 247-259.

Poutous, M. \& B. Vissac, 1962. Recherche théorique des conditions de rentabilité maximum de l'épreuve de descendance des taureaux d'insémination artificielle. Ann. Zootech. 11: 233-256.

Rendel, J. H. \& A. Robertson, 1950-1952. Estimation of genetic gain in milk yield by selection in a closed herd of dairy cattle. J. Genet. 50:1-8.

Simon, D. L., 1969. Erstellung und Einsatz einer simulierten Rinderpopulation als Instrument der Tierzüchtungslehre 1. Methodik, Programm und Auswertungsverfahren. Z. Tïrz. Züchtungsbiol. 86: 101-126.

Skjervold, H., 1966. 9th International Congress of Animal Production, Edinburgh. Edjnburgh, Oliver and Boyd, p. 250-261,

Skjervold, H. \& H. J. Langholz, 1964. Factors affecting the optimum structure of AI breeding in dairy cattle. Z. Tierz. Züchtungsbiol. 80:25-40.

Smith, C., 1969. Optimum selection procedures in animal breeding. Anim. Prod. 11 : 433-442.

Syrstad, O., 1971. Selektion for proteininhalt i mjølk. Meld. Nor. Landbrukshøgsk. 50: 27. 


\section{Appendix 1 Multiplication matrix P (for milk traits)}

Sire to breed son A generation interval of $6 \frac{3}{4}$ years is assumed (Paper I, page 4). It is therefore appropriate to define 7 age classes for males. Reproduction is $\frac{1}{4}$ in Age Class 6 and $\frac{3}{4}$ in Age Class 7. So males in Age Class 1 in a certain year contain $\frac{1}{8}$ of the genes of males in Age Class 6 in the previous year and $\frac{3}{8}$ of the genes of males in Age Class 7 in the previous year.

Sire to breed daughter, Proven bulls (SD) A generation interval of $6 \frac{3}{4}$ year is assumed. Reproduction is $\frac{1}{4}$ in Age Class 6 and $\frac{3}{4}$ in Age Class 7. With semen of proven bulls a fraction (1-y) of the inseminations is performed (Paper I, page 3). The probability that a first insemination results in a female replacement is $1 / C$. For proven bulls this probability is B (Paper I, page 3). Thus females in Age Class 1 in a certain year inherit $\frac{1}{8} \mathrm{BC}(1-\mathrm{y})$ of their genes from males in Age Class 6 in the previous year and $\frac{3}{8} \mathrm{BC}$ $(1-\mathrm{y})$ from males in Age Class 7.

Sire to breed daughter, Young bulls (YB) A generation interval of $2 \frac{3}{4}$ years is assumed. Young bulls perform a proportion $y$ of the inseminations and the probability that a first insemination results in a female replacement is A. Females in Age Class 1 in a certain year inherit $\frac{1}{8} \mathrm{ACy}$ of their genes from males of Age Class 2 of the previous year, $\frac{3}{8}$ ACy from males in Age Class 3.

Dam to breed son A generation interval of 6 years is assumed. Defining the proportion of sons (young bulls) reproduced by females in Age Class $i$ in Matrix $P$ as ds(i), the generation interval will be

$$
\mathrm{L}_{D S}=\underset{i=1}{i=n} \text { i ds(i), where } n \text { is the number of female age classes. }
$$

In Paper I, Table 1, 7 lactations (8 age classes) are considered. If the assumed generation interval is used unrealistic values of $d s(i)$ will be found. Therefore in the year approach 13 age classes for females are assumed. The values for ds(i) are given below.

$\begin{array}{llllllllllllll}\text { Age Class i } & 1 & 2 & 3 & 4 & 5 & 6 & 7 & 8 & 9 & 10 & 11 & 12 & 13 \\ \text { ds(i) } & 0 & 0 & 0.22 & 0.18 & 0.14 & 0.11 & 0.08 & 0.07 & 0.05 & 0.04 & 0.04 & 0.04 & 0.03\end{array}$


Males of Age Class 1 in a certain year receive a fraction $\frac{1}{2}$ ds(i) from females in Age Class $i$ in the previous year.

Dam to breed daughter A generation interval of $4 \frac{1}{2}$ year is assumed. The proportion of replacement daughters from females in Age Class $i$ is defined as dd(i). Values chosen for dd(i) are given below.

$\begin{array}{llllllllllllll}\text { Age Class i } & 1 & 2 & 3 & 4 & 5 & 6 & 7 & 8 & 9 & 10 & 11 & 12 & 13\end{array}$

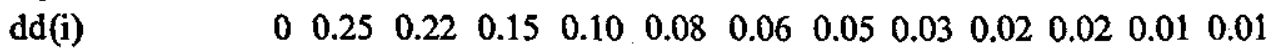




\section{Appendix 2 Vectors g and $h$}

The proportion of cows in first lactation is $1 / \mathrm{C}(=0.30)$. The fractions of cows in different age classes are given in the table below.

$\begin{array}{llllll}\begin{array}{l}\text { Vector } \\ \text { element }\end{array} & \begin{array}{l}\text { Female } \\ \text { age class i }\end{array} & \mathbf{g} & \begin{array}{l}\text { Relative } \\ \text { production, } \\ \text { average }=1\end{array} & \begin{array}{l}\text { Genetic correlation } \\ \text { between first and } \\ \text { later lactations }\end{array} & \text { h } \\ 8 & 1 & 0 & & & 0 \\ 9 & 2 & 0.30 & 0.8319 & 1.0 & 0.2496 \\ 10 & 3 & 0.20 & 0.9812 & 0.8 & 0.1570 \\ 11 & 4 & 0.15 & 1.0807 & 0.8 & 0.1297 \\ 12 & 5 & 0.10 & 1.1145 & 0.8 & 0.0892 \\ 13 & 6 & 0.07 & 1.1225 & 0.8 & 0.0629 \\ 14 & 7 & 0.05 & 1.1225 & 0.8 & 0.0449 \\ 15 & 8 & 0.04 & 1.1225 & 0.8 & 0.0359 \\ 16 & 9 & 0.03 & 1.1225 & 0.8 & 0.0269 \\ 17 & 10 & 0.02 & 1.1225 & 0.8 & 0.0180 \\ 18 & 11 & 0.02 & 1.1225 & 0.8 & 0.0180 \\ 19 & 12 & 0.01 & 1.1225 & 0.8 & 0.0090 \\ 20 & 13 & 0.01 & 1.1225 & 0.8 & 0.0090\end{array}$

The phenotypic value of Age Class $i$ equivalent to 1 unit genetic superiority in heifers depends on the genetic correlation between Lactation (i-1) and Lactation 1. Further it depends on age effects. Both are given in the above table. These values are based on the assumptions in Paper I, Table 1 . Elements 1 to 7 of vectors $g$ and $h$ are zero.

In the approach here a lactation starts at the beginning of the year. For the calculation of the monetary value of lactation yield, discounting for a period $\mathrm{x}$ is needed. This period $x$ is the time between start of lactation and the moment that half the lactation yield has been produced. To be in agreement with Paper 1, Table 1, the following expression should bold:

$$
\sum_{i=2}^{13} \text { h(i) }\left(\frac{1}{1+0.10}\right)^{i+x}=0.5474
$$

Therefore $x$ is put at 0.4879 (years). 
By the definition of Matrix $\mathbf{P}$ a cow calves first at two years of age and the calving interval is one year. Choice of elements in $\mathbf{P}$ gives realistic generation intervals, while the figure 0.4879 adjusts for the fact that a cow starts her first lactation at approximately 26 months on average and that half the lactation yield is produced about 4 months later. 


\section{Appendix 3 Multiplication matrix M (for meat traits)}

'Sire to breed daughter' Calves contain a fraction $\frac{1}{2}$ of genes from sires. These sires can be proven bulls, young bulls, both of the dual-purpose (milk/meat) breed, or bulls of beef breeds. Below are tabulated groups of calves and the source of their genes. In this table $k$ is the fraction of beef crossing; $s$ is the proportion of dualpurpose calves surviving to productive age; $s^{\prime}$ is the proportion of crossbred calves surviving to productive age.

Group of

calves

All

Dead before

productive age

purebred

crossbred

Replacement

females

Calves for

slaughter
Frequency

1

$(1-\mathrm{k})(1-\mathrm{s})$

$\mathrm{k}\left(1-\mathrm{s}^{\prime}\right)$

$1 / \mathrm{C}$
Genes from:

young bulls proven bulls beef breed $\frac{1}{2} y(1-k) \quad \frac{1}{2}(1-y)(1-k) \quad \frac{1}{2} k$

So for young bulls:

$$
\begin{aligned}
& \frac{1}{2} \mathrm{y}(1-\mathrm{k})=(1-\mathrm{k})(1-\mathrm{s}) \times \frac{1}{2} \mathrm{y}+\mathrm{k}\left(1-\mathrm{s}^{\prime}\right) \times 0+1 / \mathrm{C} \times \frac{1}{2} \mathrm{ACy}+\mathrm{S} \times \mathrm{p}_{1} \\
& \mathrm{p}_{1}=\mathrm{y}((1-\mathrm{k}) \mathrm{s}-\mathrm{A}) / 2 \mathrm{~S}
\end{aligned}
$$

For proven bulls:

$$
\mathrm{p}_{2}=(1-\mathrm{y})((1-\mathrm{k}) \mathrm{s}-\mathrm{B}) / 2 \mathrm{~S}
$$

For bulls of beef breeds:

$$
\mathrm{p}_{3}=\mathrm{ks}^{\prime} / 2 \mathrm{~S}
$$

Calves surviving to slaughter age (with Age 1 in a certain year) inherit $\frac{1}{4} \mathrm{p}_{1}$ of their genes from dual-purpose males of Age Class 2 in the previous year, $\frac{3}{4} p_{1}$ from those in Age Class $3, \frac{1}{4} \mathrm{p}_{2}$ from Age Class 6 and $3 \mathrm{p}_{2}$ from Age Class 7 . 
'Dam to breed daughter' Below are tabulated groups of calves and the source of their genes. In this table $k_{1}$ is the proportion beef crossing performed with females in Age Class $i ; s_{i}$ is the proportion of purebred calves from dams of Age Class i surviving to slaughter age; $s_{\mathbf{i}}{ }^{\prime}$ is proportion of crossbred calves from dams of Age Class $i$ surviving to slaughter age.

\section{Group of calves Frequency}

All

Dead before

productive age

Female replacement
1

$$
1-\mathrm{s}^{\prime}-(1-\mathrm{k}) \mathrm{s}
$$

$1 / \mathrm{C}$
Genes from dual-purpose females in Age Class i

$\frac{1}{2} \mathrm{~g}(\mathrm{i})$ (See Appendix 2)

$\frac{1}{2} \mathrm{~g}(\mathrm{i})\left(1-\mathrm{k}_{\mathbf{1}} \mathrm{s}_{\mathbf{i}}^{\prime}-\left(1-\mathrm{k}_{\mathbf{1}}\right) \mathrm{s}_{\mathbf{i}}\right) /$

$\left(1-\mathbf{k s}^{\prime}-(1-\mathrm{k}) \mathrm{s}\right)$

$\frac{1}{2} \mathrm{dd}(\mathrm{i})$ (See Appendix 1)

Calves for slaughter $\mathrm{ks}^{\prime}+(1-\mathrm{k}) \mathrm{s}-1 / \mathrm{C}=\mathrm{S}$

So:

$$
\begin{aligned}
& \frac{1}{2} g(i)=\frac{1}{2} g(i)\left(1-k_{1} s_{i}^{\prime}-\left(1-k_{i}\right) s_{i}\right)+1 / C \times \frac{1}{2} d d(i)+S \times p_{i} \\
& p_{1}=\left(g(i)\left(k_{i} s_{i}^{\prime}+\left(1-k_{i}\right) s_{1}\right)-d d(i) / C\right) / 2 S
\end{aligned}
$$

Assuming that $s_{i}=s$ and $s_{i}^{\prime}=s^{\prime}$ and (as in Paper III), $s=s^{\prime}, p_{i}$ reduces to

$$
\mathrm{p}_{\mathbf{1}}=(\mathrm{g}(\mathrm{i}) \mathrm{s} \rightarrow \mathrm{dd}(\mathrm{i}) / \mathrm{C}) / 2 \mathrm{~S}
$$

where $S$ reduces to $s-1 / C$.

For dual-purpose females the gene contribution to slaughter calves is given by $p_{1}$. In the calculations of discounted expressions for meat traits the reduced formula for $p_{1}$ is used.

The discounted expression per cow at birth of calves for Path $\mathbf{j}$ and an isolated Year $t$ can be calculated as

$$
\varepsilon_{\mathrm{J} t}=\mathrm{l}_{j}^{\prime}(\mathrm{t}+1) \mathrm{z}\left(\frac{1}{1+\mathrm{r}}\right)^{t}
$$

$\varepsilon_{\mathrm{jt}}$ is calculated with $\mathbf{l}_{\mathrm{j}}(t+1)$, because this vector gives the gene makeup of slaughter calves of Age 1 in Year $t+1$, or birth date in Year $t$. So the discounting is done to the value at birth of calves as in Paper III.

Vector $\mathbf{z}$ contains zeroes, except element 8. This element equals $\mathbf{S}$. 
Sonderdruck aus „Zeitschrift für Tierzüchtung und Züchtungsbiologie“

Band 90 (1973), Heft 1, S. 1-15

VERLAG PAUL PAREY - 2 HAMBURG 1 - SPITALERSTRASSE 12

Alle Rechte, auch die der Ubersetzung, des Nachdrucks, der photomechanischen Wiedergabe und der Speicherung in Datenverarbeitungsanlagen, vorbehalten. (c) 1973 Verlag Paul Parey, Hamburg und Berlin

Institute of Animal Genetics and Breeding,

The Agricultural College of Norway, Ass-NLH, Norway

\section{Model Calculations Concerning Economic Optimalization of AI-breeding with Cattle}

I. The economic value of genetic improvement in milkyield

By E. W. Brascamp

Receipt of Ms. 21.8.1972

\section{Introduction}

In order to evaluate the economic profitability of animal breeding schemes, it is necessary to estimate the costs and returns of the scheme.

Total costs include all variable costs for operating the scheme. Returns include the income from genetic improvement resulting from the scheme.

In this paper special attention will be paid to the income, the economic value of genetic improvement in milkyield.

The calculation of the economic value of the genetic improvement $(\Delta G)$ in milk yield in dairy cattle, has often been based upon some linear function of $\triangle \mathrm{G}$ (LINDHÉ, 1968, and LINDSTRÖM, 1971). Here $\triangle \mathrm{G}$ is estimated by the formula of RENDEL and ROBERTSON (1950) and represents the genetic improvement per year in $\mathrm{kg}$ milk or in $\%$ of the average milk production. This means that information on genetic superiorities and generationlengths of the selected parents are put together first in one figure $\triangle G$, and from that the monetary return is calculated.

Other methods to calculate the monetary return have been developed by Hinks (971) and McClintock and CunNingham (1972). These methods estimate the monetary return from a breeding scheme not based on $\Delta G$, but determine the economic value of the genetic superiority of selected parents as it is expressed in a certain number of generations of offspring.

These methods, however, require much calculation for each breeding scheme in a model calculation.

Based upon the approach of McCintrock and Cunningham an attempt has been made to develop a general method to estimate the monetary return which can be used in a model calculation (i. e. the result is a formula which is a function of the genetic superiority of selected parents and the proportion of a population inseminated with young bulls).

The assumption that the monetary return is a linear function of $\Delta G$ is tested. The discountfactor for the timelag between investment in A. I. and expression of $\triangle G$ in the population is defined. This discountfactor (DF) relates $\triangle \mathrm{G}$ to the monetary return, the economic value of $\Delta G$. 
It is often assumed in modelcalculations that the population size is constant. The effect of a decreasing population size on the monetary return will be discussed.

\section{Description of the method}

The economic value of genetic improvement depends on:

$1^{\circ}$ the genetic superiority of selected parents

$2^{\circ}$ the number of offspring in which the superiority is expressed

$3^{\circ}$ the time interval between the birth of the selected parents (or some chosen year zero) and the expression of the genetic superiority in the progeny

$4^{\circ}$ the genetic relationship between the selected parents and the animals which express their genetic superiority.

These points are in agreement with McCintock and CunNingham (1972). Fig. 1 shows four generations of offspring of selected parents. For each batch of female offspring the economic value of genetic superiority expressed by these daughters will be calculated. The place of the path dam to breed son (DS) is somewhat arbitrary. The dams could have been placed as parents of the group young bulls coming from SS (sire to breed son) too. The consequences of this rearrangment will be discussed.

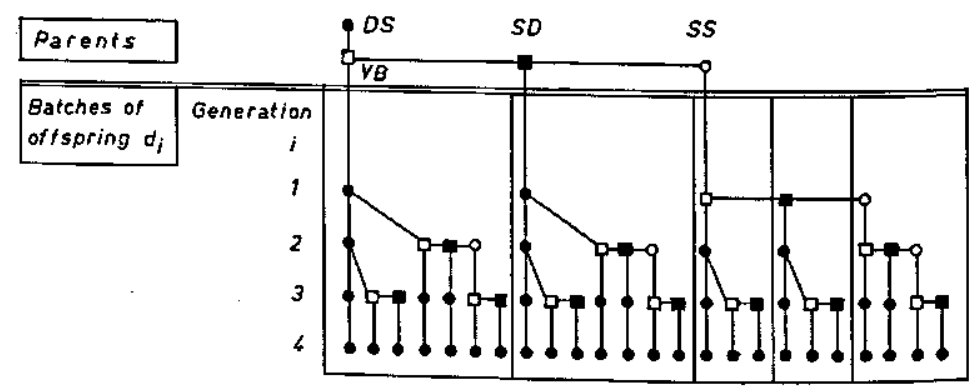

Fig. 1. The parents and the batches offspring $\left(d_{i}\right)$ when four generation DS = dams to offspring are taken into consideration $\mathrm{DS}=$ dams to breed son; $\mathrm{YB}=$ young bulls of generation zero; $\mathrm{SD}$
$=$ sire to breed daughter; $\mathrm{SS}=$ y spring; $\square=$ young bulls; $=$ sire to breed son; $O=$ batch of offspring; $\square=$ young bulls; $=$ proven bulls to breed daughter;

$\mathrm{O}=$ sires to breed son

\section{Sub $1^{\circ}$ The genetic superiority of selected parents} The genetic superiority of selected parents can be estimated as $\mathrm{R}=\mathrm{r}_{\mathrm{IO}} \cdot \mathrm{i} \cdot \sigma_{\mathrm{G}}$
where

$r_{I G}$ equals $\sqrt{h^{2}}$ or $\sqrt{\frac{0.25 \cdot p s \cdot h^{2}}{1+(p s-1) \cdot 0.25 \cdot h^{2}}}$ respectively when selection is based upon individual performance or on progeny test results. Here $\mathrm{h}^{2}$ stands for the heritability of milkyield and ps for the progeny group size. Further, the genetic standard dity of selection in standard deviation units and $\sigma_{0}$ for are not considered. 
Sub $2^{\circ}$ The number of animals in which the superiority is expressed

The method has first been developed for the three paths which can be taken to be AI paths (i. e. SS, sire to breed son; SD, sire to breed daughter; DS, dam to breed son).

In appendix 1 a survey of symbols used in the following text is given.

The numbers of animals $\left(D_{i}\right)$ in the different batches $d_{i}$ of offspring can be derived as follows:

a YB (generation zero) The number $D_{1}$ of daughters of young bulls in batch $d_{1}$ is expressed by the equation $D_{1}=A \cdot y \cdot N$ where $y$ is the proportion of the population inseminated with young bulls (which is assumed to be equal in recorded and nonrecorded herd), $\mathrm{N}$ is the population size and $A$ the chance that an offspring of a young bull enters the herd. The chance that a calf enters the herd equals $1 / \mathrm{C}$ when the replacement rate is $1 / \mathrm{C}$. Here $\mathrm{C}$ stands for the average number of lactations per cow. However, $A$ will be, dependent on $y$, lower than $1 / C$ and will only equal $1 / \mathrm{C}$ when $\mathrm{y}=1$.

$b \mathrm{SD}$ (generation zero) The number of progeny of proven bulls is expressed<smiles>CC[Al]</smiles>
by the equation $D_{1}=B \cdot(1-y) \cdot N$, where $B$ is the chance that an offspring of a proven bull enters the herd.

$A \cdot y+B \cdot(1-y)=1 / C$, assuming that the population size is constant.

The number of animals in the other batches can be derived from the number of animals in batches of previous generations.<smiles>[Mg][Mg][Mg]</smiles>

$\begin{array}{ll}d \underset{\mathrm{d}}{\mathrm{d}_{\mathrm{i}}} & \text { A cow in the population averages } \mathrm{C} \text { lactations and } \\ \underset{\mathrm{Y}}{\mathrm{YB}_{\mathrm{i}+1}} & \text { has an average chance of } \mathrm{C} \cdot \mathrm{Y} / \mathrm{N} \text { to be parent of a } \\ { }_{\mathrm{d}} & \text { young bull ( } \mathrm{Y} \text { is the number of young bulls bought } \\ \mathrm{d}_{\mathrm{i}+2} & \text { per year). }\end{array}$ $\mathrm{D}_{\mathrm{i} \div 2}=\mathrm{C} \cdot \mathrm{Y} / \mathrm{N} \cdot \frac{\mathrm{ps}}{\mathrm{m}} \cdot \mathrm{D}_{\mathrm{i}}=\mathrm{C} \cdot \mathrm{A} \cdot \mathrm{y} \cdot \mathrm{D}_{\mathrm{i}} ;$ Where $\mathrm{m}$ is the proportion recorded and ps the progeny group size.<smiles>[Y19][AsH]([AlH2])([AlH2])Cl</smiles>

For $\mathrm{d}_{1} \rightarrow \mathrm{SS}_{\mathrm{i}+1} \rightarrow \mathrm{YB}_{\mathrm{i}+2} \rightarrow \mathrm{d}_{\mathrm{i}+3}$ and $\mathrm{d}_{\mathrm{i}} \rightarrow \mathrm{SS}_{\mathrm{i}+1} \rightarrow \mathrm{SD}_{\mathrm{i}+2} \rightarrow \mathrm{d}_{\mathrm{i}+3}$ the for mulae under $d$ and $e$ respectively hold, except that $\mathrm{d}_{\mathrm{i}+3}$ must been written for $d_{i+2}$ assuming again that the population size is constant. It may be noted that $d_{i}$ represents a batch of offspring of generation $i$, and that there are different batches $d_{i}$ in generation $i$ with different numbers of animals $\mathrm{D}_{\mathrm{i}}$.

Equivalently $D_{i+2}=C \cdot B \cdot(1-y) \cdot D_{i}$ 
Sub $3^{\circ}$ Time interval between birth of the selected parents and expression of the genetic superiority in the progeny

This time interval can be split up in two parts:

a. The time interval between the birth of the selected parents and the average time of birth of a batch of progeny in which the genetic superiority is expressed. This time interval will be equal to the sum of the appropriate generation intervals $(\Sigma \mathrm{L})$ which results in a discount factor

$$
\left(\frac{1}{1+r}\right)^{\Sigma L}
$$

The assumed generationlengths are

Sire to breed son

Proven bull to breed daughter

Young bull to breed daughter

(LSS) 63/4 years

(L $\left.\mathrm{L}_{\mathrm{SD}}\right) \quad 6^{3 / 4}$ years

(LYB) $2^{3 / 4}$ years

Dam to breed son

Dam to breed daughter

$\left(\mathrm{L}_{\mathrm{DS}}\right) 6$ years

(LDD) $4 \frac{1}{2}$ years

b. The time between birth of a cow and the average expression of the genetic superiority in subsequent lactations. The value of the genetic superiority expressed by a cow discounted to the birth date of the cow can be calculated as follows (table 1).

Table 1

Steps to calculate the value of the genetic superiority expressed by a cow, discounted to its birth

\begin{tabular}{|c|c|c|c|c|}
\hline $\begin{array}{c}\text { lactation } \\
\text { number }\end{array}$ & $\begin{array}{c}(\mathrm{a}) \\
\text { proportion }\end{array}$ & $\begin{array}{c}(\mathrm{b}) \\
\text { discount factor } \\
\text { (with } \mathbf{r}=10 \% \text { ) }\end{array}$ & $\begin{array}{c}\text { (c) } \\
\text { relative } \\
\text { production } \\
\text { with average 1 }\end{array}$ & $\begin{array}{c}(\mathrm{d}) \\
\text { genetic corre- } \\
\text { lation between } \\
\text { first and later } \\
\text { lactations }\end{array}$ \\
\hline 1 & 0.300 & 0.77 & 0.836 & 1.0 \\
2 & 0.225 & 0.70 & 0.986 & 0.8 \\
3 & 0.167 & 0.63 & 1.086 & 0.8 \\
4 & 0.125 & 0.56 & 1.120 & 0.8 \\
5 & 0.094 & 0.51 & 1.128 & 0.8 \\
6 & 0.071 & 0.46 & 1.128 & 0.8 \\
7 & 0.018 & 0.42 & 1.128 & 0.8 \\
\hline
\end{tabular}
of $31 / \mathrm{s}$.

The assumptions result in an average number of lactations per cow (C)

$$
\text { The weighted discount factor will equal }{ }_{1}^{7}(\text { a) } \cdot(\text { b) } \cdot(\text { c }) \cdot(\text { d })=0.5474
$$
where (a), (b), (c) and (d) are derived from table 1.

The genetic correlation between first and later lactations has been included because most selection is based on first lactations (LindHÉ, 1968).

7

$\Sigma(a) \cdot(b)$ gives a figure in the same size order but the first one seems to 1 be most realistic under the given assumptions. 
Sub $4^{\circ}$ Genetic relationship between the selected parent and the offspring in which genetic superiority is expressed

The genetic relationship between the selected parent and the offspring is halved each generation.

Assuming that $\sigma_{\mathrm{G}}$ is given as a percentage of the average milkyield and that $1 \%$ genetic superiority values $\mathrm{p}$ money units the method will beillustrated with a certain batch $\left(\mathrm{d}_{3}\right)$. The birth of the young bull in fig. 2 is taken as year zero to which returns will be discounted.

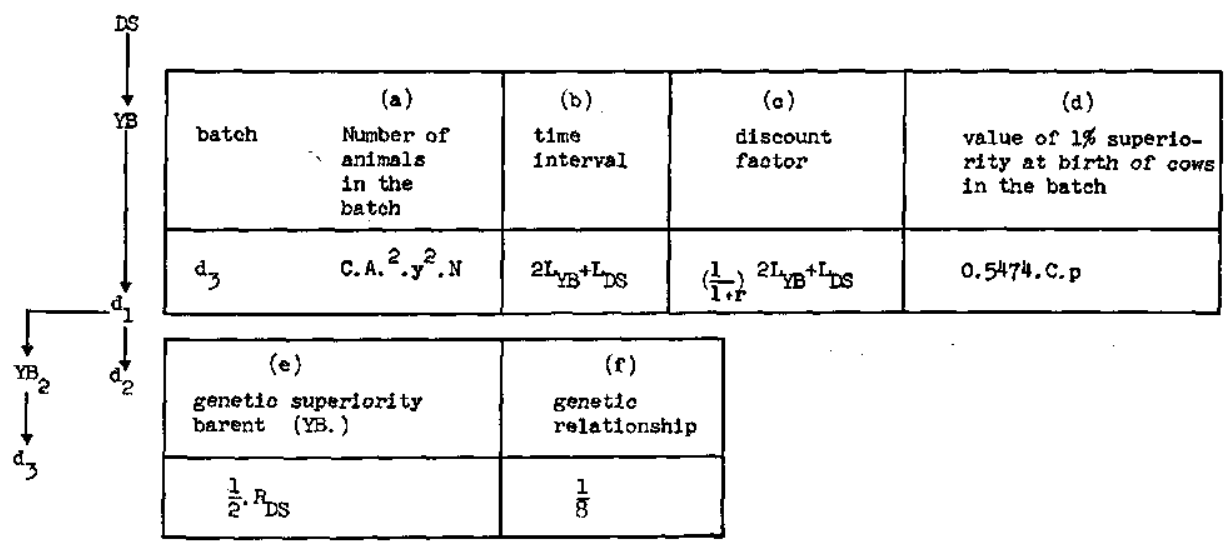

Fig. 2. Example of calculation of the economic value of genetic superiority of parentgroup DS, as expressed in the batch of offspring $d_{3}$

The product $(\mathrm{a}) \cdot(\mathrm{c}) \cdot(\mathrm{d}) \cdot(\mathrm{e}) \cdot(\mathrm{f})$ gives the economic value of the genetic superiority of the batch $\mathrm{d}_{3}$ at birth of the young bulls $\mathrm{YB}_{0}$.

The sum of products for all $\mathrm{d}_{\mathrm{i}}$-batches in fig. 1 gives the total economic value (RT) for genetic improvement calculated over a certain number of generations.

The total economic value $\mathrm{RT}$ is a function of the genetic superiorities of selected parents and the proportion of the population inseminated with young bulls. This holds for a certain population size. Futhermore RT will be dependent on $A, B, C$, the generationlengths and the interestrate. For this variables fixed figures are assumed in this paper.

In another way the economic value of $\Delta G$ (expressed in $\%$ of the average milk yield) may be estimated by means of a linear function of $\triangle \mathrm{G}$. (RL).

$$
\Delta \mathrm{G}=\frac{0.86^{1} \cdot \Sigma \mathrm{R}_{\mathrm{i}}}{\Sigma \mathrm{L}_{\mathrm{i}}}
$$

with $R_{i}$ the genetic superiority for the three paths and

$$
\begin{aligned}
& \Sigma \mathrm{L}_{i}=\mathrm{L}_{\mathrm{SS}}+(1-\mathrm{y}) \cdot \mathrm{L}_{\mathrm{SD}}+\mathrm{y} \cdot \mathrm{L}_{\mathrm{YB}}+\mathrm{L}_{\mathrm{DS}}+\mathrm{L}_{\mathrm{DD}} \\
& \mathrm{RL}=\Delta \mathrm{G} \cdot \mathrm{N} \cdot \underset{\mathrm{n}=1}{\mathrm{p}} \cdot \sum^{\infty}\left(\frac{1}{1+\mathrm{r}}\right)^{\mathrm{n}} \cdot \mathrm{DF}_{\mathrm{c}}=\mathrm{RL}^{\prime} \cdot \mathrm{DF}_{\mathbf{c}}
\end{aligned}
$$

where $R L$ is the estimate of the economic value of $\Delta G$ as a linear function $10.86=0.30 \cdot 1.0+0.70 \cdot 0.80$, see table 1 column (d) 
of $\triangle G$ and $D F_{c}$ may be considered as a constant discount factor for the timelag between investment in the breeding schema (year zero) and the expression of $\triangle G$ in the herd. This estimate represents the value of $\triangle G$, assuming that a realized $\triangle G$ is maintained infinitely many years in the population. The difference between infinite and 4 or 5 generation in the estimate RT will not be important because the discount factor for genetic superiority expressed, say 30 years after year zero, is low.

The discount factor for the timelag, DF, may therefore be estimated as $\mathrm{DF}=\frac{\mathrm{RT}}{\mathrm{RL}^{\prime}}$, where $\mathrm{DF}$ is possibly not constant.

\section{The effect of a decreasing population size}

This has been examined for the case that the population size is decreasing with a constant rate $q$ (examined are $q=0.001,0.01,0.03$ and 0.05 ). This approach has been chosen because now the number of animals in a batch $\left(D^{\prime}\right)$ at birth of the cows can be calculated as $D^{\prime}=D(1-q)^{\Sigma L}$ where $D$ is the number of animals in the batch in case of constant population size. The size of the factor $(1-q) \Sigma L$ then, decreases parallel with the discount factors used in the developement of the estimate RT (i .e. The discount factors equal $\left(\frac{1}{1+r}\right) \Sigma L$ ). Animals which come in the herd will again average $C$ lactations. In average however, the number of animals which will have lactations will be equal to $D^{\prime \prime}=D^{\prime}(1-q)^{4.5}$, where 4.5 is the average time between birth of a cow and expression of production in lactations. The figure 4.5 holds for $C=31 / 3$.

Now, the same procedure can be followed for a decreasing population size as for a constant population size with the substitution of $\left(\frac{1}{1+r} \cdot(1-q)\right) \Sigma L$ for $\left(\frac{1}{1+r}\right)^{\Sigma_{L}}$ and by multiplying the number of animals in each bath by $(1-q)^{4.5}$.

\section{Assumptions for A, B, and C}

The effect of different assumptions for A and $B$ (the chance that a calf of a young bull and of a proven bull enters the population) has been studied with
two cases:

1. $\mathrm{A}=\mathrm{B}=0.3(=1 / \mathrm{C})$

2. $A=f(y)$, a quadratic function in $y$, the proportion of the herd inseminated with young bulls where $A=0.25$ when $\mathrm{y}=0.30, \mathrm{~A}=0.30$ when $y=1.00$, and $A$ is minimal when $y=0.00 . \square \mathrm{A}=0.054945 \cdot \mathrm{y}^{2}+$ 0.245055 and $B=(0.3-A \cdot y) /(1-y)$

The first assumption $\mathrm{A}=\mathrm{B}=0.3$ seems to be the implicit assumption for the modification on the $\Delta \mathrm{G}$-estimate by SKJERvold and LANGHOLZ (1964).

$$
\text { Where } \Delta G=\frac{R_{S S}+R_{S D} \cdot(1-y)+R_{D S}+R_{D D}}{\Sigma L}
$$

Which assumption for $A$ and $B$ was taken did not essentially effect the trends in the results of the model calculation and the second has been used 
in further calculations, being probably more realistic, and will give more reliable return estimates.

All calculations have been performed in a population with 400,000 first inseminations and $60 \%$ of the population recorded. The population and assumptions underlying the model calculations are given in appendix 2.

\section{Results}

The total economic value ( $\mathrm{RT}^{\prime}$ ) of the genetic improvement can be written as:

$\mathrm{RT}=\left(\mathrm{b}_{1} \cdot \mathrm{R}_{\mathrm{SS}}+\mathrm{b}_{2} \cdot \mathrm{R}_{\mathrm{SD}}+\mathrm{b}_{3} \cdot \mathrm{R}_{\mathrm{DS}}\right) \cdot \mathrm{N} \cdot \mathrm{p}$

where the weighting factors $b_{1}$ etc. follow from the developed method.

In table 2 the values of $b_{1}$ etc. are given for different alternatives of the proportion of the population inseminated with young bulls.

The estimate for the economic value of genetic improvement as a linear function of $\triangle G$ can be written as

$$
\begin{aligned}
& \mathrm{RI}=\left(\mathrm{b}_{1}^{\prime} \mathrm{R}_{\mathrm{SS}}+\mathrm{b}_{2}^{\prime} \mathrm{R}_{\mathrm{SD}}+\mathrm{b}_{3}^{\prime} \mathrm{R}_{\mathrm{DS}}\right) \cdot \mathrm{N} \cdot \mathrm{p} \\
& =\underset{\mathrm{n}=1}{\Delta \mathrm{G}} \sum^{\infty}\left(\frac{1}{1+r}\right)^{\mathrm{n}} \cdot \mathrm{N} \cdot \mathrm{p} \cdot \mathrm{DF}_{\mathrm{C}}
\end{aligned}
$$

where $\mathrm{DF}_{\mathrm{C}}$ is some constant discount factor. Putting $\mathrm{DF}_{\mathrm{C}}$ equal to 0.35 and $r=0.10$ one finds

$$
\mathrm{RL}=\frac{\mathrm{R}_{\mathrm{SS}}+\mathrm{R}_{\mathrm{SD}} \cdot(1-\mathrm{y})+\mathrm{R}_{\mathrm{DS}}}{24-4 \mathrm{y}} \cdot \mathrm{N} \cdot \mathrm{p} \cdot 3.5 \cdot 0.86
$$

The weighting factors $b_{1}^{\prime}$ etc. are given in table 3 .

\section{Table 2}

The weighting factors $b_{1}, b_{2}, b_{3}$, for different paths in the formula for RT, the economic value of genetic improvement

\begin{tabular}{|c|c|c|c|c|c|}
\hline path & $\begin{array}{c}\text { weight- } \\
\text { ing } \\
\text { factor }\end{array}$ & \multicolumn{4}{|c|}{ Proportion of the population inseminated with young bulls } \\
& 0.20 & 0.30 & 0.50 & 0.70 \\
\hline SS & $b_{1}$ & 0.0785 & 0.0816 & 0.0880 & 0.0953 \\
SD & $b_{2}$ & 0.1945 & 0.1752 & 0.1339 & 0.0867 \\
DS & $b_{3}$ & 0.1646 & 0.1712 & 0.1853 & 0.2013 \\
\hline
\end{tabular}

Table 3

The weighting factors $b_{1}^{\prime}, b_{2}^{\prime}, b_{3}^{\prime}$, for different paths in the formula for RL, the economic value of genetic improvement, estimated as a linear function of $\Delta \mathrm{G}$

\begin{tabular}{|c|c|cc|c|c|}
\hline path & $\begin{array}{c}\text { weight- } \\
\text { ing } \\
\text { factor }\end{array}$ & \multicolumn{4}{|c|}{ Proportion of the population inseminated with young bulls } \\
& 0.20 & 0.30 & 0.50 & 0.70 \\
\hline SS & $b^{\prime}{ }^{\prime}$ & 0.1297 & 0.1320 & 0.1368 & 0.1420 \\
SD & $b^{\prime}{ }_{2}$ & 0.1038 & 0.0924 & 0.0684 & 0.0426 \\
DS & $b^{\prime}{ }_{3}^{\prime}$ & 0.1297 & 0.1320 & 0.1368 & 0.1420 \\
\hline
\end{tabular}


It follows from tables 2 and 3 that path SS is more important from the genetic than from the economic point of view. This follows from the long timelag between selection and expression of genetic superiority in daughters for the path SS compared with SD. The relative contribution by the four paths to the return and to $\triangle \mathrm{G}$ respectively will concequently be different. The relative contribution of the path SS will be lower and of the path DD higher. This is illustrated in fig. 3.

The lower contribution from path SS to the economic value of genetic improvement than to $\triangle G$ will be more stressing when less generations are taken into consideration.

The path SS is overemphasized in $\triangle G$, seen from an economic point of view, the path $S D$ is underemphasized.

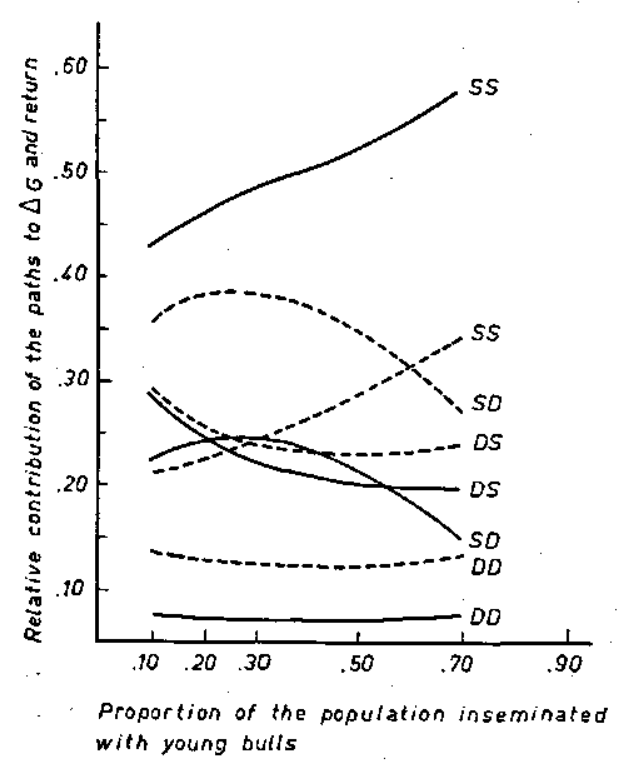

Fig. 3. The relative contribution of the four paths to the genetic improvement per year $\longrightarrow$ and to the returns $(-----)$.

The number of doses per bull is 30,000

Concequently, when $R_{S D}$ increases in the formulae for RT and RL and the other variables are kept constant, the discountfactor for the timelag, DF, will increase (i.e. $\mathrm{DF}=$ $\left.\frac{\mathrm{RT}}{\mathrm{RL}}\right)$. This is the case when the number of doses per bull stored increases. Fig. 4 shows the discount factor for the timelag (DF) for different doses alternatives and different alternatives for y. Four generations are included. The discount factor increases when the number of doses per bull increases as discussed. The effect of the proportion of the population inseminated with young bulls and the progeny group size on the discount factor is of less importance. Fig. 5 gives the same relationship as fig. 4 , but now for the paths SS and SD only. The trend proves to be the same. Where the path DS is placed in fig. 1 does not affect the trend in discount factor essentially. The only concequence of placing DS for the young bulls of SS ist that the relative contribution of the path DS to the return decreases in fig. 3 .

Fig. 6 gives the relation between $\triangle G$ from the three AI paths and the proportion of the population inseminated with young bulls for four doses alternatives. In each case that progeny group size has been selected which gives the highest $\Delta G$. (see for the alternatives examined appendix 2) These results are simular to those of SKJERVOLD and LANGHOLZ (1964) and LINDHÉ (1968).

A genetic improvement $\Delta G$ of a certain size clearly can have a different economic value (i.e. $R T=R L^{\prime} \cdot D F=\Delta G \cdot N \cdot p \cdot \sum_{n=1}^{\infty}\left(\frac{1}{1+r}\right)^{n} \cdot D F$ ). An example: The alternatives 1 and 2 in fig. 4 and 6 result in the same $\Delta G$. When the value of $1 \%$ genetic superiority, $p$, equals one money unit, the economic value of $\triangle G$ for alternative 1 and 2 are respectively 2.10 and 2.34 million money units. (The population size is 400.000 cows) 


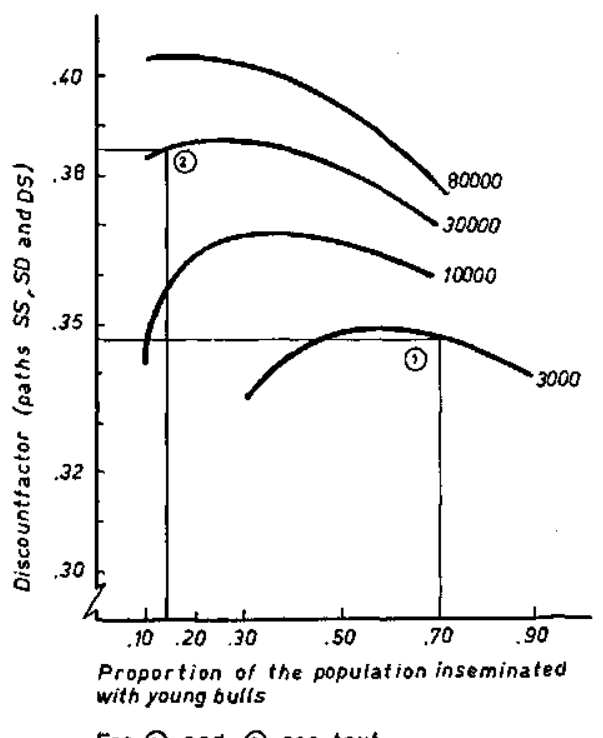

For (1) and (2) see text

Fig. 4. The relation between the discountfactor of the timelag and the proportion of the population inseminated with young bulls for different doses-alternatives

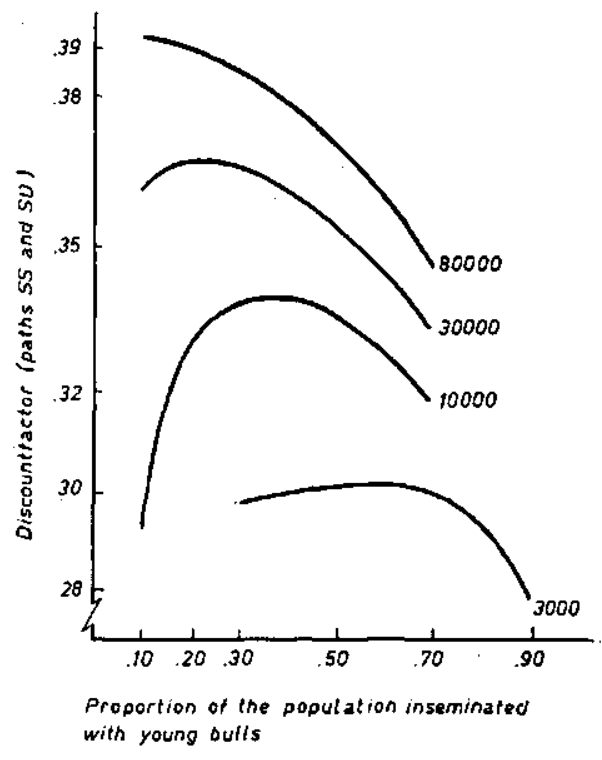

Fig. 5. The relation between the discountfactor of the timelag and the proportion inseminated with young bulls for different doses-alternatives

In Norway one money unit (p) equals 12.5 Norwegian Krones (Nkr.). Then the difference in return between alternative 1 and 2 equals 3 million $\mathrm{Nkr}$. The breeding scheme 2 will be less profitable than scheme 1 when scheme 2 is so much as 3 million Nkr. more expensive than breeding scheme 1 (net-return (return minus cost) is the criterion to select the most profitable breeding scheme).

Taking less than four generations of offspring into consideration will cause that path SS is still more overemphasized in RL and SD relatively more underemphasized. Consequently the effect of more doses stored per bull will be more stressing when less generations are taken into consideration than in the calculation done here.

\section{Table 4}

The returns from genetic improvement in a population with decreasing population size relative to those in a population of the same (constant) size at year zero. The figures reported refer to the minimal and the maximal one found for the alternatives studied

\begin{tabular}{|c|c|}
\hline decreasing rate & Relative size returns (\%) \\
\hline .001 & $98.5-98.9$ \\
.010 & $84.3-86.1$ \\
.030 & $60.6-64.5$ \\
.050 & $43.4-48.0$ \\
\hline
\end{tabular}

The effect of a decreasing population size has been studied for the case with four generations and three paths. In table 4 the results are summerized.

When the decreasing rate is $q$, the relative size of the returns roughly may be estimated as $(1-q)^{16}$.

If the number of generations taken into consideration is less than four, the 


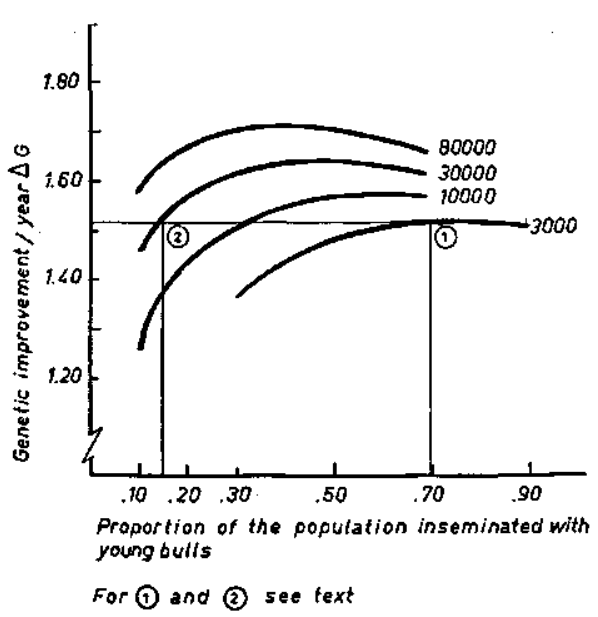

Fig. 6 . The relation between the genetic improvement per year and the proportion of the population inseminated with young bulls for different doses-alternatives

relative size of the return is higher than the figures in table 4 . The decrease in returns is mainly determined by decreasing the population size which is more desastrous when the number of years considered is higher.

The figures in table 4 may be underestimated by the assumption that decrease in population size is a random process. In reality this may not be true and decrease may consist of loss of genetically poor animals. On the other hand the figures are overestimated since the progeny group size has been calculated as given in appendix 2 . In reality the progeny group size is lower and therefore the returns less. These errors in the estimates, however, will be of minor importance.

Assuming that a breeding scheme is in operation on maximum investment level (i. e. a still higher investment level gives lower net-return because the costs increase more than the returns), every year a lower investment level should be taken. In practice however, one operates breeding schemes on a submaximal investment level, so some decrease in population size can be accepted without changing the breeding scheme.

Furthermore the decrease in population size with a constant rate may not be realistic under practical circumstances. This way of decrease was chosen because the study of the phenomenon was relatively simple.

\section{Discussion}

1. The value of $1 \%$ of the average milk production may be estimated in different ways. Often the difference between market price and feed costs is taken. Oscarsson (1968) proposes the value of saving in feeding, management, housing etc. when the cows produce $1 \%$ more milk in average. This value may be less influenced by changing market circumstances and is possibly preferable. The milk-price is often partly determined by political reasons but may also be dependent upon the total milk production in a country, total milk consumption etc.

2. A heritability $\left(h^{2}\right)$ of 0.25 is used. Some calculations however, have been made with heritabilities of 0.16 and 0.10 . The variation in the discount factor of the timelag was essentially the same.

3 . In the results inbreeding has not been taken into consideration. Assuming that $\triangle F$, the increase of the inbreeding per year and $\triangle G$ have the same discount factor (DF) for a certain alternative the returns may be estimated as

$$
\mathrm{R}=(\Delta \mathrm{G}-\mathrm{a} \cdot \Delta \mathrm{F}) \cdot \mathrm{N} \cdot \mathrm{p} \cdot \stackrel{\sum}{\mathrm{n}}=1^{\infty}\left(\frac{1}{1+\mathrm{r}}\right)^{\mathrm{n}} \cdot \mathrm{DF}
$$

where $a$ is the percentage with which $\Delta G$ decreases when the inbreeding coefficient increases by $1 \%$. 
4. The discount factor is a somewhat artificial figure. It can however, help to explain the relation between returns and an estimate of returns by a linear function of $\triangle G$. LINDHÉ (1968) in fact has used a constant discount factor of about 0.36 . The year zero in his work the year 6 in this paper.

This gives a discount factor $\frac{1}{(1+0.10)^{6}}=0.56$.

Furthermore a part of the discount factor can be found in the so called "value at birth of a calf" of one percent increase in milk yield.

This equals approximately $\frac{1}{(1+0.10)^{4.5}}=0.65$ (compare table 1).

Compared with this paper this will give a discount factor for the timelang of $0.56 \cdot 0.65=0.36$.

5 . When an infinite number of years is included in the return estimate, $(\mathrm{R})$, the relation between this return and the yearly return ( $\mathrm{Ry}, \mathrm{Ry}_{1}$, etc.) considered by LINDHÉ (1968) is given by

$$
\mathrm{R}=\underset{\mathrm{n}=1}{\mathrm{Ry} \cdot \sum^{\infty}}\left(\frac{1}{1+\mathrm{r}}\right)^{\mathrm{n}}=10 \cdot \mathrm{Ry} \text { when } \mathrm{r}=0.10
$$

Marginal yearly return equals $R y_{1}-R y_{2}$ where the subscripts 1 and 2 refer to alternatives. The difference between total return and costs (net-return) for an alternative is maximal for three alternatives with slightly increasing returns and costs when

$$
\begin{aligned}
& \mathrm{R}_{1}-\mathrm{C}_{1}=\mathrm{x} \\
& \mathrm{R}_{2}-\mathrm{C}_{2}=\mathrm{x}+\triangle \mathrm{x} \\
& \mathrm{R}_{3}-\mathrm{C}_{3}<\mathrm{x}
\end{aligned}
$$

Where $R_{2}$ and $C_{2}$ are slightly higher than $R_{1}$ and $C_{1} ; R_{3}$ and $C_{3}$ are higher than $R_{2}$ and $C_{2}$ and $\Delta x$ is positive.

Then $10 \cdot R y_{1}-C_{1}=x$

$10 \cdot R y_{2}-C_{2}=x+\Delta x$

10. $\left(\mathrm{Ry}_{2}-\mathrm{Ry}_{1}\right)=\mathrm{C}_{2}-\mathrm{C}_{1}+\triangle \mathrm{x}$

or $\frac{R y_{2}-R y_{1}}{C_{2}-C_{1}}=0.10+\frac{\triangle x}{\left(C_{2}-C_{1}\right)} 0.10$

The marginal interest rate is then

$$
\lim _{\Delta \rightarrow 0}\left(\frac{R y_{2}-R y_{1}}{C_{2}-C_{1}}\right)=\frac{\Delta R}{\Delta C}=0.10
$$

LINDHÉ accepted 0.10 for the marginal interest as a lowest level for further investment and that proves to be equivalent to taking the highest net-return.

This holds when the total return has been calculated with an interest rate equal to the lowest level of the marginal interest which justifies further investment.

6. As a criterion to select the most profitable breeding scheme maximal net-return is proposed. Net-return is defined as total return (RT) minus costs, both concerning the same scheme. In practice one may not be prepared to invest over a certain amount of money. This can be because too high insemination fees lead to loss of members to natural insemination or other AI-organisations, or since there are alternative ways of investment. Again the most profitable breeding scheme for a certain cost level can be selected with help of maximal net-return for that cost level. 
7. In the developement of a formulae for the economic value of genetic improvement an AI population is considered. Breeding animals from this population may be sold to a non AI population. When one considers income from genetic improvement in both populations as a whole there will be a longer timelag between the investment in AI and expression of genetic improvement in the herd. There will be a timelag between the expression of genetic improvement in the AI population and non AI population as described by BICHARD (1971).

8. The formulae for the economic value only hold of course for the assumptions made. The method however, is generally applicable.

\section{Summary}

A method has been developed to estimate the economic value of genetic improvement in a dairy cattle population. The ratio between this estimate and an estimate by a linear function of $\triangle G$, the genetic improvement per year, has been calculated in a model calculation for different breeding schemes. This ratio, the discount factor for the timelag between investment in $\mathrm{AI}$ and expression of genetic improvement in females in the population, proves to be not constant. Of most interest is the increase of the discount factor with increasing numbers of doses per bull. The discount factor based upon 10\% interest rate ranges $0.28-0.30$ for 3000 doses per bull up to $0.35-0.40$ for 80000 doses per bull (see fig. 4 and 5).

The contribution of the path sire to breed son to total genetic improvement proves to be of less importance from an economic than from a genetic point of view. For the path dam to breed daughter the opposite is valid (see fig. 3).

The decrease of the population size with a constant rate has large effects on the economic value of genetic improvement. When the population size decreases over about 25 years with a constant rate q per year the value of genetic improvement roughly equals $(1-\mathrm{q})^{16}$ times the value when the population size is constant.

\section{Zusammenfassung}

Eine Methode ist entwickelt worden für die Schätzung des wirtschaftlichen Wertes des jährlichen Zuchtfortschrittes in einer Rinderpopulation. In einer Modellrechnung ist, für unterschiedliche Zuchtpläne, das Verhältnis berechnet worden zwischen dieser Schätzung und einer zweiten Schätzung, die geradlinig abhängig von dem jährlichen Zuchtfortschritt ist.

Es wird gefolgert, daß dieses Verhältnis, der Diskontierungsfaktor über den Zeitraum zwischen der Investierung in die künstliche Besamung und dem Zeitpunkt, wenn der Zuchtfortschritt der weiblichen Tiere durchschnittlich realisiert wird, nicht konstant ist.

Am wichtigsten ist die Steigung des Diskontierungsfaktors mit erhöhter Anzahl Samenportionen pro KB-Bulle.

Mit 3000 Samenportionen pro Bulle ist ein Diskontierungsfaktor von $0,28-0,30$ gefunden worden, mit 80000 Portionen ein Faktor von $0,35-0,40$ (Fig. 4 und 5). Den Berechnungen zugrunde liegt eine Zinsrate von $10 \%$.

Der Anteil von Bullenvätern an den jährlichen Zuchtfortschritt ist größer 
als an dem wirtschaftlichen Wert des Zuchtfortschrittes. Für Kalbinnenmütter ist das Gegenteil gültig (Fig. 3).

Eine Abnahme des Populationsumfangs verursacht eine Senkung in Zuchtfortschritten wirtschaftlichen Wertes.

Es ist festgestellt worden, daß eine Abnahme des Populationsumfangs mit einem Faktor q, während etwa 25 Jahre eine Senkung im wirtschaftlichen Werte mit einem Faktor $(1-q)^{36}$ verursacht.

\section{Acknowledgements}

This paper was prepared during a nine months appointment of the author at the Institute of Animals Genetics and Breeding, As-NLH, Norway.

The research done during this period was the first phase of a study concerning economic optimalisation of AI-breeding at the State Agricultural University, Department of Animal Husbandry, Wageningen, the Netherlands. Financially the appointment at Ảs was made possible by a scholarship from the Norwegian Government.

The author is especially indebted to Prof. Dr. H. SkJERvold, Institute of Animal Genetics and Breeding, Âs-NLH, for many stimulating discussions and help with practical problems.

Acknowledgement is also made to the members of the Institute for suggestions and interest shown.

\section{References}

Bichard, M., 1971: Dissemination of genetic improvement through a livestock industry. Anim. Prod. 13, 401-411.

Hinks, C. J. M., 1971: The genetic and financial consequences of selection amongst dairy bulls in artificial insemination. Anim. Prod. 13, 209-218.

LINDSTRöM, U., 1971: Some points of view on the estimation and importance of genetic change in populations of dairy cattle. Ann. Génét. Sél. Anim. 3, 161-168.

LINDHE, B., 1968: Model simulation of AI breeding within a dual purpose breed of cattle. Acta Agr. Scand. 18, 33-41.

McClintock, A. E.; Cunningham, E. P., 1972: Selection in dual purpose cattle populations: Defining the breeding objective. Submitted to Anim. Prod.

Oscarsson, G., 1968: Mjelk- og kjøttproduksjonen i 1970-åra. Produksjonsuvetvecklingen. Buskap og Avdrått 2, 175-179.

ReNDEL, J. M.; Robertson, A., 1950-1952: Estimation of genetic gain in milk yield by selection in a closed herd of dairy cattle. J. Genetics 50, 1-8.

SKJERVOLD, H.; LANGHOLZ, H. J., 1964: Factors affecting the optimum structure of AI breeding in dairy cattle. $Z$. Tierziichtg. Züchtbiol. 80, 25-40.

Sмгтн, C., 1969: Optimum selection procedures in animal breeding. Anim. Prod. 11, 433-442.

Autbor's address: E. W. Brascamp, Department of Animal Husbandry, State Agricultural University, Duivendaal 5, Wageningen, the Netherlands

\section{Appendix 1}

List of variables and constants used in the text.

1. Variables and constants to determine the breeding scheme

$\mathrm{N}$ : population size

$m$ : proportion of the population recorded 
do : number of doses stored per bull

$y \quad$ : proportion of the population inseminated with young bulis

ps : progenygroup size.

2. Variables and constants related to the number of offspring in which genetic superiority of parents its expressed, and related to genetic superiority.

$\mathrm{d}_{\mathrm{i}}$,

$\begin{aligned} & d_{\text {batch }} \text { of } \\ & \text { cows }\end{aligned}$
$\leftarrow-C:$ average number of lactations per cow
(1/C: replacement rate in herds)

$\left.\begin{array}{l}\text { daughters } \\ \text { entering } \\ \text { the herd }\end{array}\right\} \leftarrow$ father $\left\{\begin{array}{l}\text { young bull (YB) } \leftarrow \text { A: chance that a calf of a young } \\ \text { bull enters the herd } \\ \text { proven bull (PB) } \leftarrow \text { B: chance that a calf of a proven } \\ \text { bull enters the herd. }\end{array}\right.$

$Y$ : number of young bulls bought per year.

$\mathrm{SS}, \mathrm{SD}, \mathrm{YB}, \mathrm{DS}, \mathrm{DD}$ : paths over which genes are transmitted to the next generation. SS sire to breed son; SD proven bull to breed daughter; YB young bull to breed daughter; DS dam to breed son; DD dam to breed

$\mathrm{R}$ : genetic superiority daughter.

$\mathrm{L}$ : generation interval

$\triangle \mathrm{G}:$ genetic improvement per year

3. Economic variables and constants

$r \quad$ : interest rate

RT : total monetary return from the breeding scheme

RL : total monetary return from the breeding scheme, calculated as a linear function of $\triangle \mathrm{G}$

DF : discountfactor for the timelag between investment in $A I$ and the expression of $\Delta G$ by females in the population

$D_{p}$ : a constant discountfactor for the timelag.

\section{Appendix 2}

Alternatives studied in the model calculation, and assumptions made to restrict the number of alternatives.

Assumed is a breeding policy where deepfrozen doses are stored up to a certain amount. The bulls are slaughtered when the doses needed are produced. After progeny testing all doses of selected bulls are used in the following year.

\section{Alternatives}

Proportion of the population inseminated with young bulls progeny group size

\section{Assumptions}

Population size

Replacement rate in herds $(1 / C)$

Number of preselected dams per young bull

Number of doses/pregnancy

as Number of tested daughters/dose in recorded herds

( $A$ is the chance that a calf of a young bull enters the herd)

a Proportion of the recorded population which is potential bull dam

a 7 Proportion of the population recorded $\square$ heritability (some calculations have been done with 0.16 and 0.10 )

a Average milk, production

ag Phenotypic standard deviation as a percentage of the average milkproduction

a 10 Number of bull sires/year 
The alternatives and assumptions lead to the following features in the model calculation.

Number of young bulls/year: $A \cdot y \cdot a_{1} \cdot a_{7} / p s=Y$

Number of proven bulls: $(1-\mathrm{y}) \cdot \mathrm{a}_{1} \cdot \mathrm{a}_{4} / \mathrm{do}=\mathrm{PB}$

Proportion selected (s)

SS $a_{10} / Y$

$\mathrm{SD} \mathrm{PB} / \mathrm{Y}$

DS $\quad a_{3} \cdot Y /\left(a_{1} \cdot a_{7} \cdot a_{6}\right)$

DD $1-a_{2}$

In case of decreasing population size the progeny group size for an alternative has been taken equal to ps. of $\mathrm{r}_{\mathrm{IT}}$.

In fact one should take the "realized" progeny group size (ps. [1-q] $\mathrm{L}_{\mathrm{YB}}$ ) for calculation

The selection intensities (i) are estimated with the formula of SMITH (1969) $\mathrm{i}=0.8$ $+0.41 \cdot \ln \left(\frac{1}{\mathrm{~s}}-1\right)$. Some alternatives are lost then because of intensity estimates which are not accurate enough.

The genetic superiorities can be calculated for each alternative. From that: the genetic improvement per year and the economic value of genetic improvement. 
VERLAG PAUL PAREY - HAMBURG 1 - SPITALERSTRASSE 12

Alle Rechte, auch die der Ubersetzung, des Nachdrucks, der photomechanischen Wiedergabe und der Speicherung in Datenverarbeitungsanlagen, vorbehalten, (C) 1973 Verlag Paul Parey, Hamburg und Berlin

Department of Animal Husbandry, State Agricultural Universily, Wageningen, The Netberlands - Head of the Depariment: Prof. Dr. R.D. Politick

\section{Model calculations concerning economic optimalization of AI-breeding with cattle}

\section{Effect of costs on the optimum breeding plan}

By E.W. Brascamp

With 3 Figures

Receipt of Ms. 19.2. 1973

\section{Introduction}

In recent years many mathematical models on optimalization of AI breeding plans have been made.

For instance, the calculations of SKJERvold and LANGHOLz (1964) mainly concerned the genetic aspects of optimalization.

To determine optimum schemes LiNDHÉ (1968), Hinks (1970), Hill (1971) and HARING (1972) included the costs for a breeding plan.

Hinks (1970) and Oscarsson and Lindié (1970) compared the waiting-bull system with the system of storing deep-frozen semen which involves slaughtering young bulls early in life.

It is difficult to compare the results of different models because of different cost assumptions and because the criteria used for the optimum breeding plan may differ.

In this paper the effect of different econom:c situations on the optimum breeding plan was studied. Net return was used as a criterion to select an optimum. The returns from a scheme were calculated according to Brascamp (1973). Also was studied how cost factors affect the relative profitability of the two management systems, i.e. waiting-bull system and the storage of deep-frozen semen.

\section{Methods and description of the model}

The mathematical model described in this paper only concerns milk yield, so that the different combinations of variables to be studied is restricted. Moreover in dairy cattle, milk yield is the main trait that determines the economic result of selection on milk yield and composition (SYRSTAD 1971, Brascamp and MinkeMA 1972). Including growth rate in the model will not affect the results essentially if the correlation between milk yield and growth rate is close to zero. 
The effect of costs on the optimum breeding plan was studied for two management systems :

A. Storage of deep-frozen semen. Immediately after collecting semen of young bulls required for progeny test, a certain predetermined number of doses are collected and stored until the progeny test results are known. As soon as the number of doses needed per bull is produced, the bulls are slaughtered.

B. Waiting-bull system. When the doses for progeny test are collected the bulls are not used for AI until the progeny test results are known. Only some doses, enough to produce a new batch of young bulls from three bull sires, are stored. When the progeny test results are known some bulls are selected for use in AI. Of these bulls again a predetermined number of doses will be produced.

To shorten the generation interval in both management systems, the semen of proven bulls was used in the population as soon as possible. In the mathematical model the effect of costs on the optimum breeding plan was studied for different combinations of population size and proportion of the population recorded.

Also the number of doses that an adult bull can on average produce annually was varied. These variables are given in Table 1 , together with variables which describe a breeding scheme. Symbols given are used in the text. The assumptions underlying the model and the values studied for the different variables are given in Appendix 1.

To study the effect of costs on optimalization of breeding 12 different combinations of cost factors, called cost alternatives, are considered. These are partly based upon actual situations (Table 2). In Table 3, the 12 cost alternatives are summarized. The

Table 1

Variables in the model and symbols used

\begin{tabular}{|ll|c|}
\hline $\begin{array}{l}\text { to determine the } \\
\text { population }\end{array}$ & $\begin{array}{l}\text { population size } \\
\text { proportion of the population } \\
\text { recorded } \\
\text { annual semen production } \\
\text { per adult bull } \\
\text { number of doses sampled } \\
\text { to describe the } \\
\text { breeding plan }\end{array}$ & $\mathrm{m}$ \\
& $\begin{array}{l}\text { per bull } \\
\text { progeny group size } \\
\text { proportion of the population } \\
\text { inseminated with young bulls }\end{array}$ & $\mathrm{s}$ \\
\hline
\end{tabular}
data in Table 3 were obtained by setting the milk price to one for each cost alternative, and setting the different cost factors to one for cost alternative 1 . The other figures are proportional to them. As an example, for cost alternative 10 the value of a5 is calculated from Table 2 as:

$$
\frac{0.05}{0.02}: \frac{0.17}{0.25}=3.7
$$

Thus it can be shown to what extent two cost alternatives differ from each other.

Cost alternative 1 represents the situation in Norway; the alternatives 2 to 8 were chosen by changing one or more cost factors in cost alternative 1 (Table 3 ).

Cost alternatives 9 to 11 represent the situations in Sweden, Great Britain and the Netherlands, respectively. Alternative 12 was included to study the effect of lower net milk price in the Dutch situation. The milk price Hfl. 0.30 may be seen as market price minus feed costs, where Hfl. 0.10 is an approximate value of $1 \mathrm{~kg}$ milk, according to the approach of Oscarsson (1968).

With the 12 cost alternatives an attempt was made to cover extreme situations to make general conclusions possible.

The following results were calculated per alternative (i.e. per combination of the variables) 


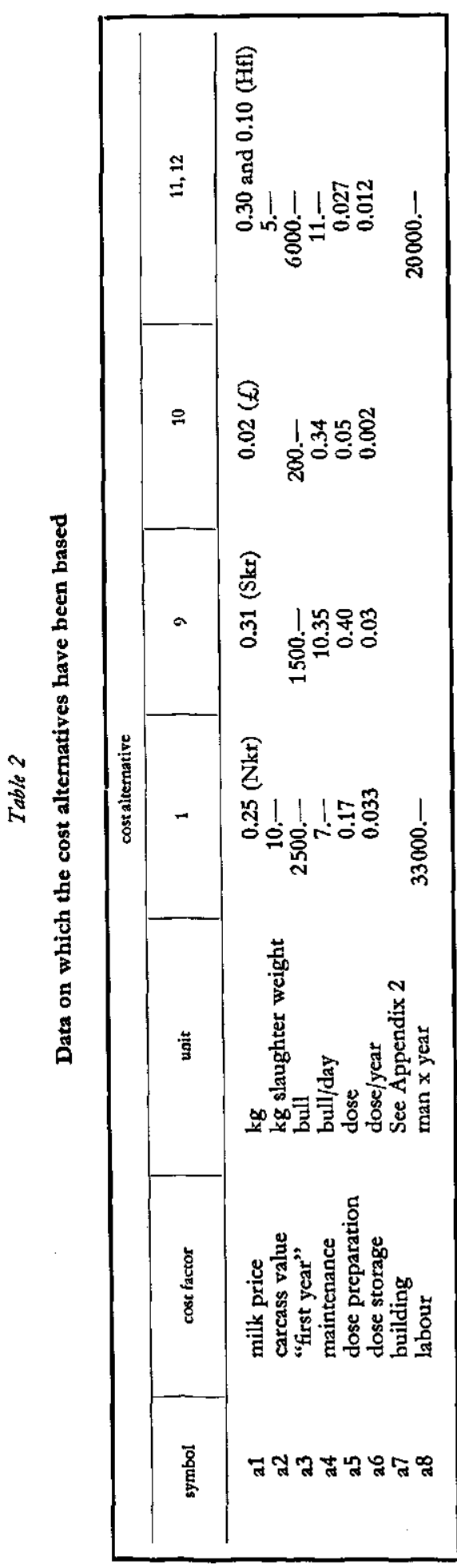

1. genetic improvement in $\%$ per year $(\triangle G)$ according to RENDEL and RoBERTSON (1950);

2. increase in inbreeding per year $(\Delta F)$ (LINDHÉ 1968);

3. returns per cow over 4 generations offspring discounted to a base year (BRAsCamp 1973).

The year of birth of the batch of young bulls is taken as base year;

4. discount factor for the time lag (DF) between investment in $\mathrm{AI}$ and the average time of expression of genetic improvement (BRASCAMP 1973);

5. Costs per cow (C). The way of calculating costs from the data given in Table 3 are found in Appendix 2;

6. total returns, corrected for inbreeding (R'T), were calculated with the formula: $\mathrm{R}^{\prime} \mathrm{T}=(\Delta \mathrm{G}-\mathrm{a} \cdot \Delta \mathrm{F}) \cdot 10 \cdot \mathrm{p} \cdot \mathrm{DF}$

It is assumed that $\Delta G$ decreases by $1 \%$ when $\Delta \mathrm{F}$ increases by $1 \%(\mathrm{a}=1) ; \mathrm{p}$ is the net value of $50 \mathrm{~kg}$ milk $(1 \%$ of the assumed average milk yield per cow per year). The figure 10 comes from:

$$
\sum_{n=1}^{\infty} \frac{1}{(1+r)} n=10
$$

for an interest rate $(t)$ of 0.10 ;

7. net return per cow $(\mathrm{NR}): \mathrm{NR}=\mathrm{RT}-\mathrm{C}$ The optimum breeding plan in a certain population has been defined as the breeding plan with the highest net return per cow.

As discussed by Fewson and Niebel (1972) this criterion can be considered as satisfactory.

In practice, breeders are often not prepared to invest in insemination fees above a certain level. Therefore suboptimum plans were calculated at different cost levels lower than the cost level for the optimum plan. The suboptimum breeding plan was defined as the plan with the highest net return per cow for a certain cost level.

\section{Presentation of the results}

Returns, costs and net returns per cow have been given in 'money units'. One money unit has been defined as the net value of 
Table 3

Summary of cost alternatives

(relative to $\mathrm{al}=1$ and cost alternative $1=1$ )

\begin{tabular}{|l|l|l|l|l|l|l|l|l|l|l|l|l|}
\hline \multicolumn{10}{|c|}{ cost alternative } \\
\hline symbol & 1 & 2 & 3 & 4 & 5 & 6 & 7 & 8 & 9 & 10 & 11 & 12 \\
\hline $\mathrm{a} 1$ & 1 & 1 & 1 & 1 & 1 & 1 & 1 & 1 & 1 & 1 & 1 & 1 \\
$\mathrm{a} 2$ & 1 & 1 & 1 & 1 & 1 & 1 & 1 & 1 & 1 & 1 & 0.40 & 1.20 \\
$\mathrm{a} 3$ & 1 & 5 & 1 & 1 & 1 & 1 & 1 & 1 & 0.5 & 1 & 2.0 & 6.0 \\
$\mathrm{a4}$ & 1 & 1 & 1 & 1 & 2 & 3 & 1 & 2 & 1.2 & 0.6 & 1.3 & 3.9 \\
$\mathrm{a} 5$ & 1 & 1 & 2 & 3 & 1 & 1 & 5 & 0.5 & 2 & 3.7 & 0.13 & 0.4 \\
$\mathrm{a} 6$ & 1 & 1 & 1 & 1 & 1 & 1 & 5 & 0.5 & 0.75 & 0.75 & 0.30 & 0.9 \\
$\mathrm{a} 7$ & 1 & 1 & 1 & 1 & 1 & 1 & 1 & 1 & 1 & 1 & 0.35 & 1 \\
$\mathrm{a} 8$ & 1 & 1 & 1 & 1 & 1 & 1 & 1 & 1 & 1 & 1 & 0.55 & 1.65 \\
\hline
\end{tabular}

$1 \mathrm{~kg}$ of milk. So, the data for the milk price in Table 3 are given in money units. Thus results of different cost alternatives are directly comparable. Different kind of runs were made on computer, as indicated in Appendix 1. This is reported with the results where necessary.

\section{Results and discussion}

\section{Management system A}

For a large population size (in this study $\mathrm{N}=400000$ and $\mathrm{N}=$ one million), for all cost alternatives the optimum was found at the same high number of doses stored per bull.

Generally it can be concluded that it is profitable to produce semen until about one year after the progeny test results are known.

The optimum number of doses stored per bull is affected by population size and dose production per adult bull per year.

The proportion of the population recorded did not influence the optimum number of doses stored per bull, see Table 4.

\section{Table 4}

Optimum number of doses stored per bull dependent on populationsize (N) and number of doses produced per adult bull per year (s)

\begin{tabular}{|c|c|c|c|}
\hline$s$ & N (thousand) & $\begin{array}{c}\text { optimum number of doses } \\
\text { (thousad) do }\end{array}$ & $\begin{array}{c}\text { time needed to produce } \\
\text { the doses (jears) }\end{array}$ \\
\hline 15000 & 50 & 20 & 1.8 \\
& 400 & 80 & 6.3 \\
25000 & 1000 & 80 & 6.3 \\
& 50 & 20 & 1.2 \\
35000 & 400 & 135 & 6.4 \\
& 1000 & 135 & 6.4 \\
& 50 & 20 & 0.9 \\
& 400 & 180 & 6.1 \\
\hline
\end{tabular}


The conclusion that collection of semen for about 6 years is profitable does not hold for $\mathrm{N}=50000$. It was assumed that the number of proven bulls is not lower than three.

Because of this assumption very high numbers of doses can not be used in small populations and will therefore not be produced.

Fig. 1 illustrates the relation between returns and costs for different dose alternatives for cost alternative 7. (The curves were calculated with Step 3, Appendix 1.)

For Fig. $1 \mathrm{~N}=400000, \mathrm{~m}=0.60$ and $\mathrm{s}=25000$. The optimum breeding plan for cost alternative 7 was found at the cost level of 42 money units $(N R=236$ money

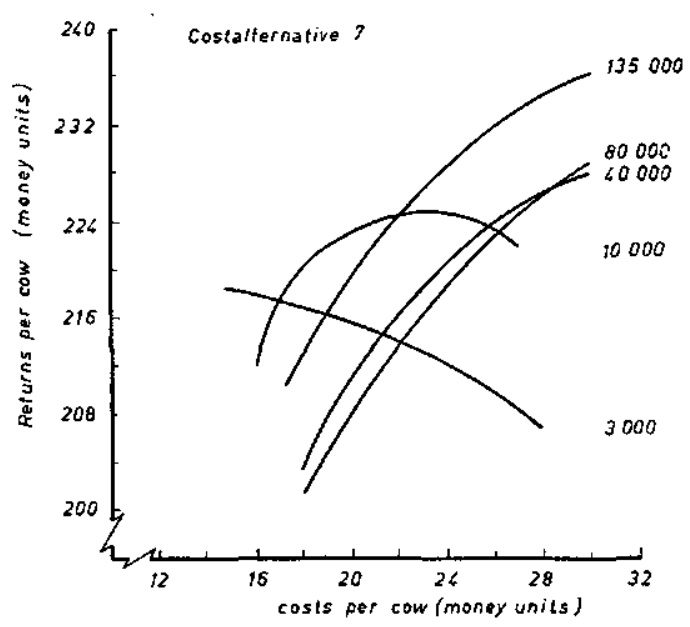

Fig. 1. The relation between costs and returns per cow for different dose alternatives units). Under a cost level of about 22 money units, 135000 doses stored per bull was no longer optimum. For cost alternative 10 the 135000 dose curve also resulted in lower net returns for low cost levels than other curves. For the other alternatives, however, the 135000 dose curve gave higher net returns than the other curves over the whole range of cost levels.

As for the optimum breeding plan, the suboptimum breeding plans were found at the same optimum number of doses stored, except for cost alternatives with high costs for semen preparation and storage and low costs for management and feeding.

Table 5 gives the optimum schemes and the suboptimum sche- mes for the 5 money units cost level at different dose alternatives. Now cost alternative 1 is taken. Also $\Delta G$ and $D F$ are given. For the suboptima per dose alternative it can be seen that, even though $\Delta G$ decreases for the suboptimum per dose alternative, the net return increases for a higher number of doses per bull. This is caused by an increase of the discount factor for the time lag (DF).

\section{Table 5}

Maximum net returns (NR) and costs (C) per dose alternative for the optimum and a suboptimum

(cost level 5)

\begin{tabular}{|c|c|c|c|c|c|c|c|c|c|c|}
\hline \multirow[b]{2}{*}{$\begin{array}{c}\text { number } \\
\text { of } \\
\text { doses/bull }\end{array}$} & \multicolumn{5}{|c|}{ Optimurn } & \multicolumn{5}{|c|}{ Suhoptimum } \\
\hline & NR & c & $\begin{array}{c}\text { number } \\
\text { of } \\
\text { young } \\
\text { bulls }\end{array}$ & $\Delta \mathbf{G}$ & DF & NR & c & $\begin{array}{c}\text { number } \\
\text { of } \\
\text { young } \\
\text { bulls }\end{array}$ & $\Delta G$ & DF \\
\hline 3000 & 224 & 5.3 & 156 & 1.43 & 0.347 & 215 & 4.9 & 152 & 1.40 & 0.340 \\
\hline 10000 & 242 & 15.6 & 311 & 1.53 & 0.361 & 216 & 4.8 & 78 & 1.35 & 0.353 \\
\hline 40000 & 262 & 26.4 & 180 & 1.59 & 0.387 & 209 & 4.6 & 30 & 1.26 & 0.368 \\
\hline 80000 & 271 & 22.5 & 90 & 1.57 & 0.398 & 215 & 5.0 & 20 & 1.24 & 0.383 \\
\hline 135000 & 274 & 28.3 & 90 & 1.60 & 0.402 & 223 & 4.9 & 15 & 1.24 & 0.395 \\
\hline \multicolumn{11}{|c|}{ Cost alternative 1 is taken. For $\Delta G, D F$ and units see text. } \\
\hline
\end{tabular}


To illustrate the effect of costs on the optimum breeding plan, a calculation with smaller steps between alternatives for $y$ and $p s$ was done for $\mathrm{N}=400000, \mathrm{~m}=0.60$, $s=25000$. This situation is valid for some Scandinavian countries and, in the future, probably for the Netherlands as well. Higher population size and values for $\mathrm{m}$ did not influence the results essentially.

The optimum number of doses stored per bull for this model was 135000 . For this high number, the costs were about linearly related with the number of young bulls.

In Fig. 2 the return curve and the cost lines are given as functions of the number of young bulls. Higher costs, especially costs for semen preparation and storage make the slope of the cost lines steeper. Consequently the optimum number of young bulls is lower. Maximum returns of 318 money units was found with 360 young bulls. The optimum breeding plans then realized $89-95 \%$ of the maximum returns.

Optima were found by variation in $y$ and ps. It was found, however, that for the optima in most cases the proportion of the population inseminated with young bulls was between 0.20 and 0.30 .

The optimum number of young bulls for different cost alternatives, then, was mainly determined by variation in the progeny group size.

For different population sizes and cost alternatives the optimum number of young bulls is given in Table 6 . The effect of $m$ was only slight.

For a population of more than 400000 the optimum number of young bulls was about proportional to the population size; the returns per cow did not increase much.

For $\mathrm{N}=50000$ a higher number of young bulls per cow was profitable. The costs per young bull were then lower because of the lower number of doses per bull, which makes more young bulls per cow profitable.

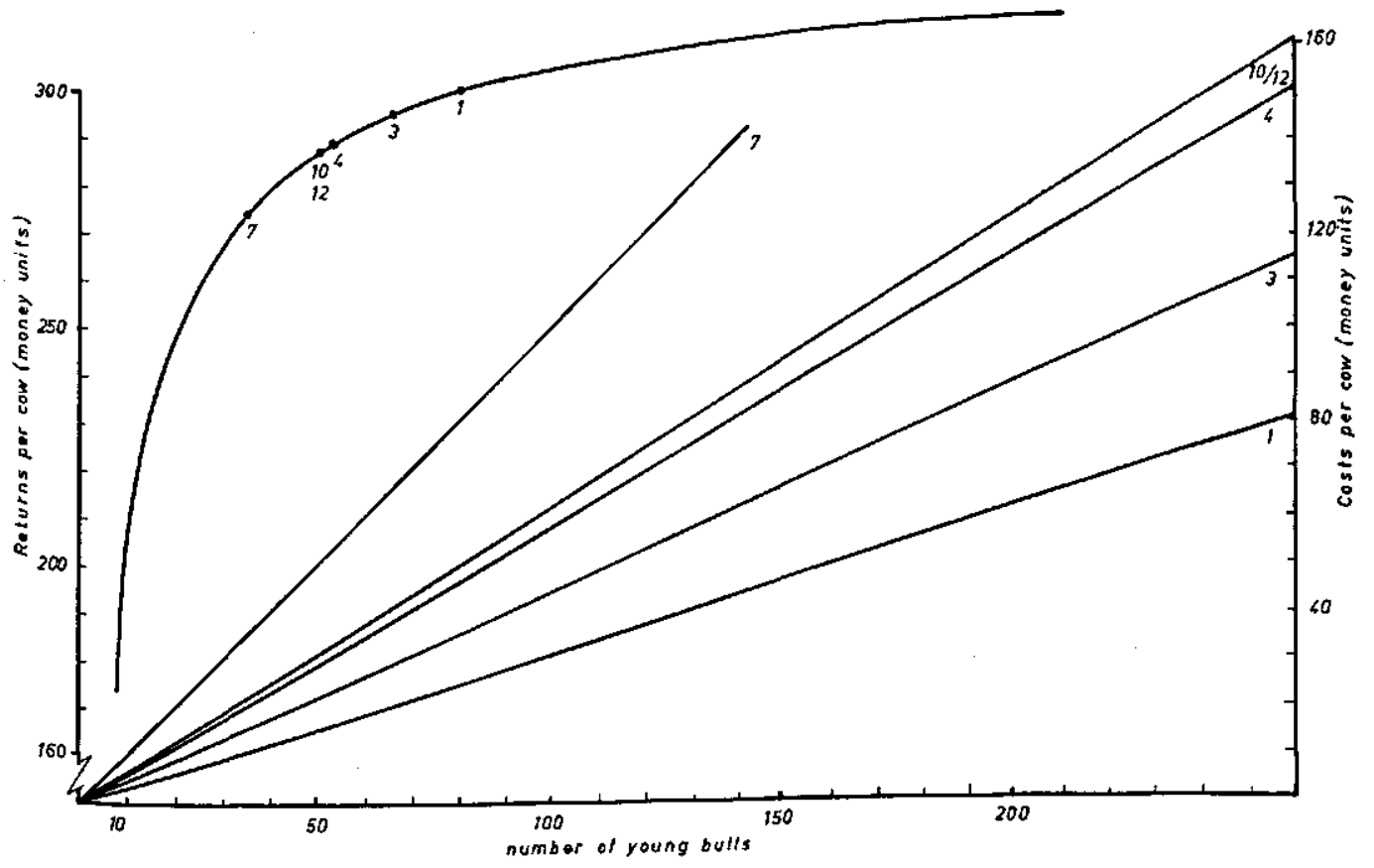

Fig. 2. Relation between the number of young bulls and returns and costs per cow for different cost alternatives $(1,3,4,7,10$ and 12$), N=400000$. The dots in the return curve are optima per cost alternative. 
Table 7 gives an example of optimum breeding plans for different population sizes. Only breeding schemes for cost alternatives 1 and 7 are given. The alternatives 1 and 7 represent situations with low and high costs for semen preparation and storage, respectively. In all cases the proportion recorded was 0.60 .

Table 6

The optimum number of young bulls for $N=50000$ and $N=400000$ and different cost alternatives

\begin{tabular}{|r|r|r|r|r|r|r|}
\hline \multicolumn{7}{c|}{ Optimum number of young bulls } \\
\hline population size & \multicolumn{7}{c|}{ cost alternative } \\
\hline & 1 & 3 & 4 & 7 & 10 & 12 \\
\hline 50000 & 26 & 26 & 23 & 15 & 21 & 15 \\
400000 & 79 & 65 & 55 & 35 & 50 & 50 \\
\hline
\end{tabular}

\section{Table 7}

Optimum breeding plan for different population size ${ }^{1}$

Cost alternatives 1 and 7

\begin{tabular}{|l|ccc|crr|}
\hline cost alternative & \multicolumn{3}{c|}{1} & \multicolumn{3}{c}{7} \\
\hline $\mathrm{N}$ (thousand) & 50 & 400 & 1000 & 50 & 400 & 1000 \\
s (thousand) & 25 & 25 & 25 & 25 & 25 & 25 \\
do (thousand) & 20 & 135 & 135 & 20 & 135 & 135 \\
ps & 100 & 200 & 200 & 200 & 425 & 300 \\
y & 0.35 & 0.30 & 0.30 & 0.40 & 0.25 & 0.20 \\
number of young bulls & 26 & 90 & 225 & 15 & 35 & 99 \\
number of proven bulls & 3 & 4 & 10 & 3 & 4 & 12 \\
DF & 0.41 & 0.40 & 0.39 & 0.42 & 0.40 & 0.39 \\
$\Delta G$ o & 1.23 & 1.60 & 1.74 & 1.15 & 1.46 & 1.62 \\
Return (money units/cow) & 234 & 302 & 319 & 218 & 274 & 295 \\
Net return & 215 & 274 & 290 & 181 & 237 & 253 \\
Costs & 19 & 28 & 28 & 38 & 37 & 42 \\
\hline
\end{tabular}

1 The number of young bulls and proven bulls is rounded to the nearest integer. Then the total need of doses in the population is not always covered.

\section{Discussion part I}

The conclusion of the results is that a very intensive use of proven bulls is profitable. A lower optimum number of young bulls was found than reported by SKJERYoLD (1966) and LindHÉ (1968). Also the number of doses per bull stored was higher. This could be explained as follows: first that increasing the number of doses per bull gives a higher discount factor for the time lag as reported by BRASCAMP (1973). This increase outweights a possible decrease in $\Delta G$ for suboptimum plans and an increase in costs; second that doses, which are produced a year after the progeny test results are known, are very cheap. Only doses of selected bulls are produced and storage costs are negligible. However, there is a considerable gain in selection intensity.

This fact is illustrated in Fig. 1 where the net return curve for do $=135000$ is above the curve for do $=80000$ over the whole range of costs levels, while other curves intersect. 
Collection of a still higher number of doses per bull proves to be unprofitable. Then the generation interval increases too much. In optimum schemes the low number of young bulls should be tested with rather large progeny groups. This was also found by Hinks (1970). The very intensive use of proven bulls as given by this model (see Table $7, \mathrm{~N}=50000$ and 400000 ) may be not realistic in practice, where some more choice among available bulls is preferred.

Costs for milk recording were not included. It is difficult to decide which part of the costs should be payed by selection and which part should be covered by other fields of milk production, e.g. management and feeding.

It was found, however, that increase of $\mathrm{m}=0.30$ up to $\mathrm{m}=0.60$ gives an increase in net return per cow (i.e. excluding costs for milk recording) of 15-20 money units comparing optima and suboptima for different alternatives of $\mathrm{m}$.

If milk recording is payed for only by genetic improvement from $\mathrm{AI}$ paths, the increase of $\mathrm{m}$ from 0.30 up to 0.60 is justified when the costs of this increase are lower than $15-20$ money units per cow. The same holds for an increase of $m=0.60$ up to 1.00 .

\section{Management system B}

Because $s$ and $m$ do not influence the trend of results these variables were fixed at $\mathrm{s}=25000$ and $\mathrm{m}=0.60$ to restrict the number of calculations. Again an optimum number of doses per bull stored was found. For $\mathrm{N}=50000$ the optimum number of doses per bull was found to be 20000 , for $N=400000$ it was 60000 .

Which of the two systems gives the highest net returns will mainly be determined by the maintenance costs and the costs for dose preparation and storage.

For $N=400000$ it was found that for cost alternative 7 (with costs for dose preparation and storage 5 times as high as in cost alternative 1) the net returns for systems $\mathrm{A}$ and $\mathrm{B}$ were equal. For the other cost alternatives the optimum breeding scheme of System A gave higher net returns than the optimum scheme of System B (see Table 8).

In Fig. 3 the returns for cost alternative 4 are given for systems $A$ and $B$ as a function of costs. The optimum scheme for System A was found at cost level $\mathrm{C}=$ 30.7 money units and $R$ $=288$, for System $B$ at $\mathrm{C}=17.0$ and $\mathrm{R}=257$.

If the cost level $C$ was lower than 11.5 money units the returns for System $B$ were higher than for System A. It wasfound that the same holds for cost alternative 10 , if $C$ was smaller than 11 money units. Cost alternatives 4,7 and 10 were all alternatives with high doses preparation and storage costscompared withmaintenance costs.

For $\mathrm{N}=50000$ cost alternative 7 again gave

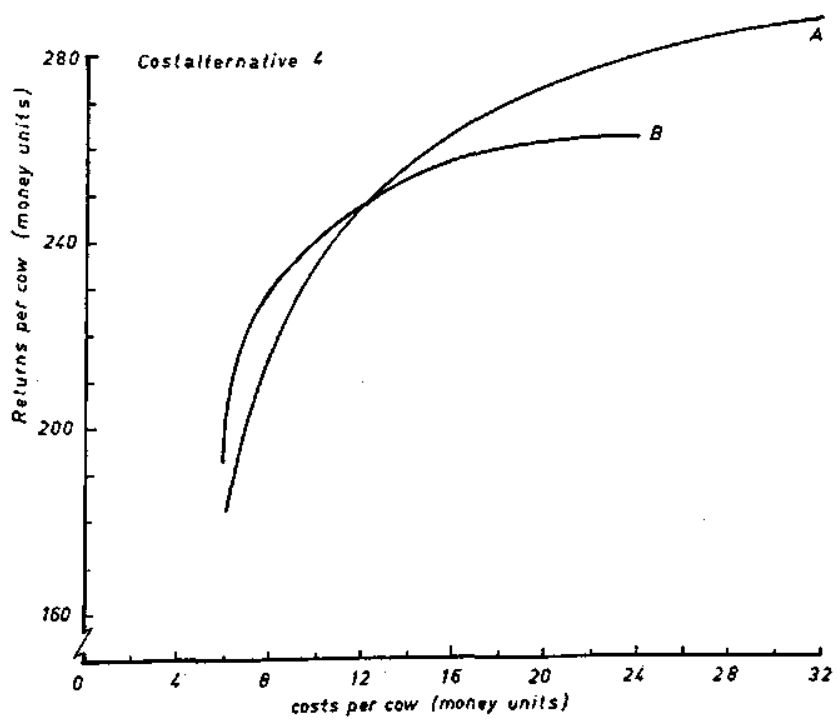

Fig. 3, The relation between returns and costs per cow for two management systems, $A$ and $B$ 
Table 8

Comparison of management systems $A$ and $B$ for different cost alternatives for symbols and units see text

\begin{tabular}{|c|c|c|c|c|c|c|c|c|c|c|c|}
\hline \multirow{2}{*}{$\frac{\mathrm{N}=400000}{\text { cost }}$} & \multicolumn{5}{|c|}{ System A (135000 doses/bull) } & \multicolumn{6}{|c|}{ System B (60000 doscs/bull) } \\
\hline & NR & c & $\Delta \mathrm{G}$ & DF & $\begin{array}{l}\text { number of } \\
\text { young bulls }\end{array}$ & NR & c & $\Delta G$ & DF & $\begin{array}{c}\text { number } \\
\text { of } \\
\text { young } \\
\text { bulls }\end{array}$ & \begin{tabular}{|c} 
difference \\
NR \\
$\mathbf{A - B}$
\end{tabular} \\
\hline $\begin{array}{r}1 \\
4 \\
6 \\
7 \\
10 \\
12\end{array}$ & $\begin{array}{l}275 \\
258 \\
258 \\
237 \\
255 \\
255\end{array}$ & $\begin{array}{l}25 \\
31 \\
31 \\
37 \\
33 \\
33\end{array}$ & $\begin{array}{l}1.58 \\
1.53 \\
1.53 \\
1.46 \\
1.53 \\
1.53\end{array}$ & $\begin{array}{l}0.40 \\
0.40 \\
0.40 \\
0.40 \\
0.40 \\
0.40\end{array}$ & $\begin{array}{l}79 \\
53 \\
53 \\
35 \\
53 \\
53\end{array}$ & $\begin{array}{l}242 \\
240 \\
219 \\
237 \\
244 \\
210\end{array}$ & $\begin{array}{l}15 \\
17 \\
32 \\
20 \\
20 \\
41\end{array}$ & $\begin{array}{l}1.49 \\
1.49 \\
1.46 \\
1.49 \\
1.53 \\
1.46\end{array}$ & $\begin{array}{l}.37 \\
.37 \\
.37 \\
.37 \\
.37 \\
.37\end{array}$ & $\begin{array}{r}104 \\
104 \\
78 \\
104 \\
155 \\
78\end{array}$ & $\begin{array}{r}33 \\
18 \\
39 \\
-0 \\
11 \\
46\end{array}$ \\
\hline $\mathrm{N}=50000$ & \multicolumn{5}{|c|}{ System A (20000 doses/bull) } & \multicolumn{6}{|c|}{ System B (20000 doses/bull) } \\
\hline $\begin{array}{r}1 \\
4 \\
6 \\
7 \\
10 \\
12\end{array}$ & $\begin{array}{l}205 \\
202 \\
200 \\
181 \\
201 \\
185\end{array}$ & $\begin{array}{l}19 \\
27 \\
28 \\
38 \\
27 \\
33\end{array}$ & $\begin{array}{l}1.23 \\
1.21 \\
1.21 \\
1.15 \\
1.21 \\
1.15\end{array}$ & $\begin{array}{l}.41 \\
.41 \\
.41 \\
.42 \\
.41 \\
.42\end{array}$ & $\begin{array}{l}26 \\
23 \\
21 \\
15 \\
21 \\
15\end{array}$ & $\begin{array}{l}190 \\
188 \\
154 \\
186 \\
194 \\
140\end{array}$ & $\begin{array}{l}27 \\
29 \\
50 \\
31 \\
27 \\
56\end{array}$ & $\begin{array}{l}1.19 \\
1.19 \\
1.11 \\
1.19 \\
1.22 \\
1.08\end{array}$ & $\begin{array}{l}.40 \\
.40 \\
.40 \\
.40 \\
.40 \\
.40\end{array}$ & $\begin{array}{l}24 \\
24 \\
15 \\
24 \\
31 \\
13\end{array}$ & $\begin{array}{r}15 \\
14 \\
46 \\
-5 \\
7 \\
45\end{array}$ \\
\hline
\end{tabular}

higher net return for System B than for System A. The return curves do not intersect as in Fig. 3 for $N=50000$. Here all cost alternatives (exept 7) give optima and suboptima under System A.

\section{Discussion part II}

The optimum schema for $\mathrm{N}=400000$ was System $\mathrm{A}$ in most cases. Here the optimum number of doses stored per bull was 135000 and the bulls were not slaughtered before the progeny test results were known. So, System A is System B with storage of semen and is therefore more expensive. This is not so for $\mathrm{N}=50000$. Then optimum schemes for System A are less expensive than those for System B because very high dose numbers for $\mathrm{N}=50000$ are not possible.

This difference probably accounts for why the return curves in Fig. 3 do not intersect for $\mathrm{N}=50000$ while for $\mathrm{N}=400000$ they do.

\section{Discussion}

1. Some calculations were done for a modification of management system $B$, in which there was no storage of doses. Consequently costs will be lower.

Also selection intensities for the path sire to breed son will be lower because of the assumption that $75 \%$ of the initial number of young bulls survives until the progeny test results are known. The modification showed lower net returns.

2. For the model it was assumed that young bulls are used equally in recorded an non-recorded herds. It could also be assumed that young bulls and first selection proven bulls are used in recorded herds, while second selection proven bulls are used in non-recorded herds. These two assumptions were compared. 
The difference in net return per cow for both possibilities was only small, the net return for the second assumption was slightly higher.

3. The optimum and suboptimum schemes given are not exact, of course. For instance, an optimum number of doses stored per bull of 135000 means between 120000 and 180000 . But to discuss general trends, it is not necessary to be more exact.

4. In Table 8 lower population size with constant $y, p s$ and do gives a higher discount factor for the time lag. This is because the relative contribution of the path sire to breed daughter to the returns increases compared with the path sire to breed son (the intensity of selection for SD does not change while the intensity for SS decreases) (BrasCAMP 1973).

5. The variable $s$ in the model is considered to be the maximum semen production technically possible for an average bull.

Thus with large population size as many doses as possible will be produced annually, i.e. $s$ doses per bull. When $s$ does not indicate a technical maximum, more than $\mathrm{s}$ doses per year should be produced from the proven bulls in breeding schemes with semen production after progeny test results are known.

Also on the cost side money may be saved by applying schemes of dose production other than with a constant production every year. In certain combinations of $\mathrm{N}$ and $\mathrm{s}$ this will be the case.

Suppose the number of proven bulls is set to certain minimum number and suppose with maximum yearly dose production the semen, required from that number of proven bulls, is produced just before the progeny test results are known.

An alternative way to produce the doses needed is to produce less doses until the progeny test results are known. Then the remaining number of doses is sampled from selected bulls only. Costs may be lower then. Returns will decrease slightly by increase of the generation interval. In general it is impossible to predict the effect on net return.

This discussion indicates, however, that for System $A$ an optimum number of doses produced per bull per year may exist.

For System B the doses should be produced as fast as possible. If the annual dose production is not limited technically, the relative profitability of systems A and $B$ will change.

Results of a calculation for an AI organization in the Netherlands with 200000 first inseminations showed that for System $A$ an annual production of 15000 doses per bull was optimum. If production of over 35000 doses per bull per year was technically possible, System $B$ was found to be more profitable. An aspect which is left out of this model is to what extent fertility of semen is dependent on the age of the bull and the period during which the semen has been stored. Older bulls possibly produce less fertile semen, but long storage may also have a negative effect on fertility of semen. When optimum dose production schemes are considered fertility of semen should be included.

6. Hinks (1970) found that for British economic circumstances management system $\mathrm{B}$ was preferable. The purpose of his paper seems to be to select a suboptimum breeding plan which is applicable in practice, because of lower costs compared with an optimum.

For cost alternative 10 it was found that System B was preferable to System A for suboptimum plans under a certain cost level.

7. One should be very careful with conclusions about some optimum population size from Table 7. As pointed out in Appendix 2, only variable costs were taken into consideration. Furthermore the consequences of a bigger AI organization for management, possibility of public relations have not been included in the model. They are difficult to predict, too. In theory an infinite population size seems to 
give the highest net return per cow. With increase of the population size the extra net return decreases, however. For the alternatives for $\mathrm{N}$ studied, a profitable breeding plan was found to be possible. Practical problems related with scale will be of importance when increase of size of an AI organization is considered.

HARING (1972) concludes that a population size of 1 million cows is needed for a profitable breeding scheme. This could not be showed in this study.

8. In studies on AI optimalization, different criteria are used to select the optimum breeding scheme.

As pointed out by BRASCAMP (1973) the criterion marginal rate of interest $\left(\mathbf{P}_{\mathrm{m}}\right)$, used by LINDHE leads to the same optimum as the criterion maximum net return used in this paper. If $\mathrm{P}_{\mathrm{m}}$ the ratio of differences between annual return to differences between costs for two alternative breeding plans is more than some minimum value $(10 \%$, say), the more expensive one of the two plans should be adopted.

If this minimum value is not fixed beforehand, calculation of marginal rate of interest is advantageous but involves many combinations of two plans. If the minimum value is known beforehand net return has computational advantage, because it is to be calculated for each plan only. Both methods assume that the genetic improvement from a scheme is maintained in time without requiring further investment for this maintenance (LINDHÉ 1968).

The criterion adopted by HrNks (1970) is relative efficiency. Then the ratio of differences in returns to differences in costs of two schemes should be at least one before the more expensive scheme is adopted. This leads to identical results as the net return criterion.

LINDHÉ worked with annual returns and HINKs with accumulated returns over a certain period of time as in this paper. Suboptimum schemes in this paper are found by looking for the scheme with the highest net returns for a certain cost level. Hinks (1970) found suboptimum schemes by setting the lowest level of relative efficiency not to one but over one. Both ways of approach probably lead to equivalent results. Nrebel and Fewson (1972) discussed the merits of the method of internal interest rate and of the pay-off system. They concluded that aiming at breeding plans with highest internal interest rate or with shortest pay-off period in detecting optimum breeding schemes favours extensive schemes with non-maximum net returns.

HARING (1972) used net returns as criterion. Furthermore the pay-off period should not be too long for an optimum breeding scheme. It is unclear to what extent this restriction influences the results of an optimalization.

\section{Acknowledgments}

The work for this paper was begun during a nine months appointment at the Institute of Animal Genetics and Breeding, As-NLH, Norway. I thank E.A. Fimland for discussion and valuable suggestions.

\section{Summary}

The effect of costs for AI breeding on optimalization of the breeding plan was studied. In total 12 cost alternatives were considered and defined (Table 3). A suboptimum breeding plan for a certain cost level was adopted to cover situations where one is not prepared to invest the amount of money in AI breeding as justified by comparison of costs and returns related to a breeding plan.

Two management systems were compared, the waiting-bull system (B) and storage of deepfrozen semen with slaughtering of bulls early in life (A). Net return was used to select optimum and suboptimum breeding plans. 
For most cost alternatives optimum and suboptimum breeding plans were found for System $\mathrm{A}$ with the same high number of doses per bull (Table 4). Also System A was found to be preferable in those cases. Exceptions were cost alternatives with high costs for semen preparation and storage and low costs for management and feeding. Then for low cost levels, the suboptima were found for management system B and for System A, suboptima were found at a lower number of doses (Figs. 1 and 3).

Net returns for optimum and suboptimum breeding plans increase with larger population size. The model was too simple to determine which population size, was optimum. For the alternatives for all population sizes studied, schemes were worthwhile from an economical point of view (Table 7).

Some consideration was given to the proportion of the population in milk recording.

\section{Zusammenfassung}

\section{Modellkalkulationen zur Optimierung der Wirtscbaftlicbkeit der KB-Zucbt beim Rind}

Die Wirkung der Kosten einer KB-Zucht auf die Optimierung des Zuchtplanes wurde untersucht. Dazu wurden insgesamt 12 Kostenalternativen entwickelt und beschrieben. Der Begriff eines suboptimalen Zuchtplanes wurde für ein bestimmtes Kostenniveau geprägt. Dieser trifft in jenen Situationen zu, in denen man nicht bereit ist, einen nach Aufwand und Ertrag entsprechenden Preis für die KB-Zucht zu bezahlen.

Zwei Systeme wurden in die Untersuchung einbezogen:

1. Die Wartebullenhaltung (B)

2. die Lagerung von Tiefgefriersperma, wobei die Bullen frühzeitig geschlachtet werden (A).

Die Bestimmung der optimalen und suboptimalen Zuchtpläne erfolgte über die Netto-Erlöse.

Für die meisten Kostenalternativen wurden optimaler und suboptimaler Zuchtplan bei System A bei gleicher Anzahl von Samenportionen pro Bulle gefunden ('Tab. 4), System A ist in solchen Fällen vorzuziehen. Ausnahmen hiervon bilden Alternativen mit hohen Kosten für Samenaufbereitung und Lagerung und niedrigen für die Bullenhaltung. Bei diesen niedrigen Kosten lag das Sub-Optimum bei System B; für System A lag das Sub-Optimum bei einer geringeren Anzahl von Samenportionen pro Bulle (Darstellung 1 und 3).

Die Nettoerlöse der optimalen und suboptimalen Zuchtpläne nehmen bei steigender Populationsgröße zu. Anhand des angewandten Modells konnte die optimale Populationsgröße nicht festgestellt werden. Es zeigte sich, daß für alle untersuchten Alternativen für Populationsgrösse ein positiver wirtschaftlicher Erfolg gefunden wurde (Tab. 7).

In die Untersuchung wurde auch die Größe der aktiven Zuchtpopulation (Anteil Kühe unter Milchkontrolle) einbezogen.

\section{References}

BrASCAMP, E.W., 1973: Economic optimalization of cattle breeding with artificial insemination. I. The econornic value of genetic improvement in milk yield (in print).

BrAsCAMP, E.W.; MinKEMA, D., 1972: Economic aspects of selection for Milk, fat-\% and protein-\% in a dairy cow AI population. $Z$. Tierzüchtg. Züchtgsbiol. 89, 99-108.

Haring, H. J.F., 1972: Die Zuchtplanung in der Rinderzucht aus ökonomischet Sicht. Diss. Göttingen.

HrLL, W. G., 1971 : Investment appraisal for national breeding programmes. Anim. Prod. 13, 37-50.

HinKs, C. J.M., 1970: The selection of dairy bulls for artificial insemination. Anim. Prod. 12, 569-576.

LindHE, B., 1968: Model simulation of AI breeding within a dual purpose breed of cattle. Acta Agr. Scand. 18, 33-41.

NIEBEL, E.; Fewson, D., 1972: Methodik der Zuchtplanung für die Reinzucht beim Rind. LH Hohenheim; Inst. f. Tierzucht.

Oscarsson, G., 1968: Mjølk - of Kjøttproduksjonen i 1970 - ara Produktsjonsutvecklingen. Buskap og Avdrått 2, 175-179.

OscaRsSON, G.; LINDHE, B., 1970: Spermakostnader i seminverksamheten SHS Meddelande 36.

RENDEL, J.M.; ROBBRTSON, A., 1950-1952: Estimation of genetic gain in milk yield by selection in a closed herd of dairy cattle. J. Genetics 50, 1-8.

SKJERvold, H., 1966: 9th Int. Congress of Animal Production, Edinburgh. Edinburgh: Oliver and Boyd. 250-261.

SKJERVOLD, H.; LANGHOLz, H. J., 1964: Factors affecting the optimum structure of AI breeding in dairy cattle. Z. Tierzüichtg. Züchtgsbiol. 80, 25-40.

SYRstAd, O., 1971: Selektion for proteininhalt i mjølk. Meldinger fra Norges Landbrukshøgskole, 50,27 . 


\section{Appendix 1}

\section{Assumptions}

\section{Population structure}

A : the probability that a calf of a young bull enters the dairy herd

B : the probability that a calf of a proven bull enters the dairy herd

b1: replacement rate

$$
\begin{aligned}
& \mathrm{A}=0.054945 \cdot \mathrm{y}^{2}+0.245055 \\
& \mathrm{~B}=(\mathrm{b} 1-\mathrm{A} \cdot \mathrm{y}) /(1-\mathrm{y}) \quad \text { (from BRASCAMp 1973) }
\end{aligned}
$$$$
\mathrm{b} 1=0.30
$$

\section{Breeding scheme}

b2: number of preselected dams per young bull

b3: number of doses per pregnancy

b4: proportion of the recorded population which is a potential bull dam

b5: number of bull sires per year

b6: proportion of the initial number of young bulls (YB)

surviving until the progeny test results are known

$\mathrm{b} 2=30$

$\mathrm{b} 3=2.0$

$\mathrm{b} 4=0.50$

$\mathrm{b} 5=3$

$\mathrm{b} 6=0.75$

It is assumed that between year 1 and 6 the number of surviving young bulls decreases every year by 0.05 . YB young bulls.

Bullsires are assumed to be selected from 0.9875 . YB young bulls. When doses are stored and young bulls are slaughtered early in life it is assumed that proven bulls can be selected from YT young bulls, from which in average do doses/bull have been stored. Then YT is the arithmic mean of the number of young bulls surviving until test semen is produced and the number until do doses are produced.

\section{Generation intervals}

SS: Sire to breed son 6.75 years

SD: Sire to breed daughter

DS: Dam to breed son $6.75-4 \cdot y+(1-y) \cdot L E$

DD: Dam to breed daughter

$\mathrm{LE}$ is the increase of the generation interval for proven bulls for

a. waiting-bull system

b. doses storage system when do doses can not be produced until year 6. The extra time (EX) needed after year 6 to produced do doses is calculated in the computer program (EX is dependent of $s$, no decrease in surviving number of bulls is

Then assumed).

a. $\mathrm{LE}=0.5$. $\mathrm{EX}$

b. $L E=0.5 \cdot E X \cdot(1-($ do6 - dot $) /$ do $)$, where dot is the number of doses produced per bull for a progeny test, and do 6 the number of doses produced per bull until year 6 .

\section{Calculations from assumptions and variables}

Number of young bulls per year $\quad \mathrm{YB}=\mathrm{A} \cdot \mathrm{y} \cdot \mathrm{m} . \mathrm{N} / \mathrm{ps}$

Number of proven bulls per year $P B=(1-y) \cdot N$. b3 $/$ do with $3 \leqq \mathrm{~PB}<\mathrm{Y}$ T 


\section{Proportion selected}

SS b5/YB . 0.9875

$\mathrm{SD} \mathrm{PB} / \mathrm{Y}^{\prime} \mathrm{T}$

DS b2 . YB/N.m.b4

\section{Alternatives studied}

The calculations have been done in different steps.

step 1

$\begin{array}{llccccccc}\mathrm{N} & \text { (thousand) } & 50 & 400 & 1000 & & & & \\ \mathrm{~m} & & 0.30 & 0.60 & 1.00 & & & & \\ \mathrm{~s} & \text { (thousand) } & 15 & 25 & 35 & & & & \\ \mathrm{y} & & 0.10 & 0.20 & 0.30 & 0.50 & 0.70 & 0.90 & \\ \text { ps } & & 50 & 75 & 100 & 150 & 200 & 300 & 400\end{array}$

These alternatives were calculated for management systems $A$ and $B$ with the following alternatives for number of doses per bull:
A do (thousand)
510
30
$\begin{array}{llll}80 & 120 & 135 & 180\end{array}$
220

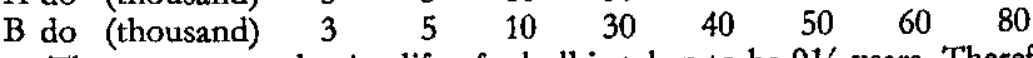

The average productive life of a bull is taken to be $91 / 2$ years. Therefore the high doses numbers of system A can not be realized in system $B$ when $s$ is limited.

step 2

When an optimum number of doses was found and general conclusions about $y$ and ps were drawn, calculations were done as follows:

E.g.

$\mathrm{N}$ (thousand) 400

$\mathrm{m} \quad 0.60$

s (thousand) 25

do (thousand) 135

$\begin{array}{lllllll}\text { y } & 0.10 & (0.05) & 0.50 & & & \\ \text { ps } & 100 & (25) & 450 & 500 & 550 & 600 .\end{array}$

step 3

For further restriction of the number of calculations results were selected in the computer program.

E.g. with Fig. 1, returns per cost level, for one cost alternative.

$\mathrm{N}$ (thousand) 400

m 0.60

s (thousand) 25

do (thousand) 3

y 0.10

$\begin{array}{lccc}\text { ps } & 0.10 & (25) & 400 \\ \text { cost levels } & 6.50-7.50,5.50-6.50,4.50-5.50,3.50-4.50 \text {. }\end{array}$

\section{Appendix 2}

Costs

Costs were first calculated as the sum of costs per subsequent period of half a year, discounted to the base year. 
For different alternatives the length of time the bulls are on AI station differs very much.

Because of this variation it was found unsatisfactory to work with one formula to calculate costs. The apptoach described took much computer time. To meet this, some approximations were adopted.

\section{a2 carcass value}

The income from slaughtered bulls was calculated from a dressing $\%$ of $52 \%$ and

Table 9

Relation between age and liveweight for bulls on $\mathrm{AI}$ station

\begin{tabular}{|c|c|}
\hline age (years) & liveweight (kg) \\
\hline 1 & 425 \\
2 & 725 \\
$>3.5$ & 900 \\
\hline
\end{tabular}
the following growth curve for the bulls (Table 9). Intermediate values for liveweight were found by linear interpolation.

$$
\text { a3 first year }
$$

In one case (cost alternative 1) costs of young buils up to year 1 were taken, where the bulls were bought at $1 / 4$ year old.

In other cases the costs of bull purchase at one year old were taken.

\section{a5 doses preparation \\ a6 doses storage}

It is assumed that during the first year on $\mathrm{AI}$ station a bull can produce $65 \%$ of its adult semen production, during the first half year $31 \%$.

\section{a7 building}

Only variable costs were considered. This seems reasonable for comparison of alternatives with a given population size. For comparison of alternatives with varying population sizes also "fixed" costs should be taken into consideration (e.g. costs of a laboratory, to some extent independent of intensity of use).

However, for comparison of different population sizes other problems such as organisation and management should be included although they are not taken into consideration here.

In Norwegian circumstances one place for a bull in an AI station was assumed to

\section{Table 10}

Relation between the size of an Al station and the costs per place

(relative to the number of places is 10 )

\begin{tabular}{|c|c|}
\hline number of places & costs/place \\
\hline$<10$ & 1.00 \\
20 & 0.76 \\
40 & 0.65 \\
100 & 0.54 \\
$>200$ & 0.44 \\
\hline
\end{tabular}
cost $1070 \mathrm{Nkr}$ per year, for a building with 10 places. The number of places needed is found by multiplying the number of bulls on station per year by the number of years.

A larger building was assumed to be cheaper according to the data in Table 10 (Intermediate values were found by linear interpolation).

\section{a8 labour}

It was assumed that one man is needed for 40 bulls.

Autbor's adress: E. W. Brascamp, Department of Animal Husbandry, State Agricultural University, Duivendaal 5 , Wageningen, The Netherlands 


\section{Berichtigung zu}

Zeitschrift für Tierzüchtung und Züchtungsbiologie Bd. 91 (1974), H. 3

VERLAG PAUL PAREY

Im Beitrag BrasCAMp - "Model calculations concerning economic optimalization of AI-breeding with cattle, III. Profitability of performance testing in a dual-purpose breed according to meat production and the effect of beef crossing" - wurde für Fig. 2. (S. 181) die Legende versehentlich nicht mitabgedruckt.

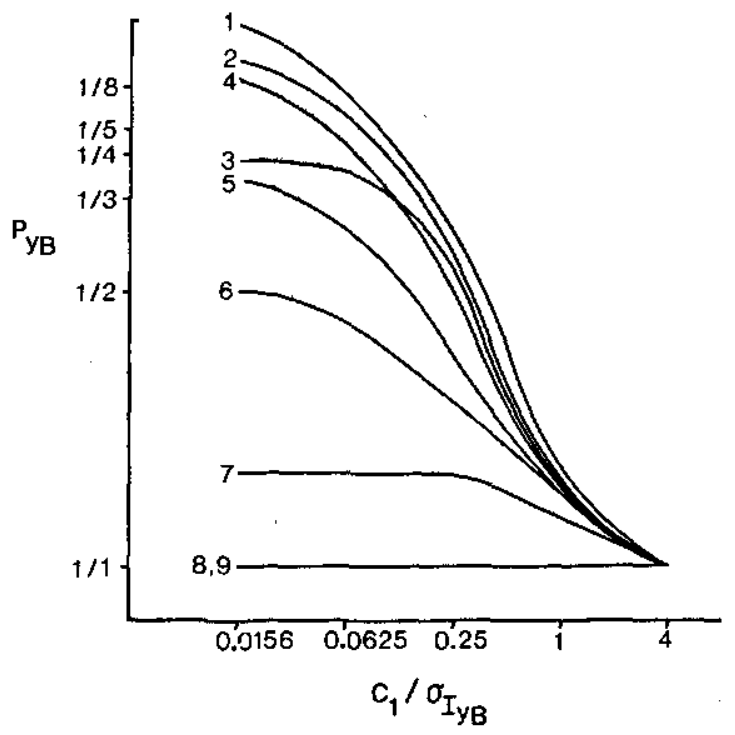

Fig. 2. Symbols used:

$\begin{array}{ccc}\text { curve } & \sigma_{\text {IDS }} / \sigma_{\text {IYB }} & \text { p } \\ 1 & 0.25 & 0.001 \\ 2 & 0.25 & 0.064 \\ 3 & 0.25 & 0.256 \\ 4 & 1.00 & 0.001 \\ 5 & 1.00 & 0.064 \\ 6 & 1.00 & 0.256 \\ 7 & 4.00 & 0.001 \\ 8 & 4.00 & 0.064 \\ 9 & 4.00 & 0.256\end{array}$

$\sigma_{\text {IYB }}$ standard deviation of the index for performance-test selection (for units, see text)

$\sigma_{\text {IDS }}$ standard deviation of the index for selection of dams to breed sons

PDS selected proportion for path DS at PYB $=1$

$c_{1}$ costs for performance test, expressed per cow, at $\mathrm{PYB}_{\mathrm{B}}=1$

PYB proportion selected after performance test 


\author{
VERLAG PAUL PAREY - HAMBURG 1 - SPITALERSTRASSE 12 \\ Rechte, auch die der Ubersetzung, des Nachdrucks, der photomechanischen Wiedergabe und der Speicherung \\ in Datenverarbeitungsanlagen, vorbehalten, (C) 1974 Veriag Paul Parey, Hamburg und Berlin
}
Department of Animal Husbandry, State Agricultural University, Wageningen, the Netherlands Head of the Department: Prof. Dr. R.D. Politick

\title{
Model calculations concerning economic optimalization of AI-breeding with cattle
}

\section{Profitability of performance testing in a dual-purpose breed according to meat production and the effect of beef crossing}

By E.W. BRASCAMP

Ms. received 14.3. 1974

\section{Introduction}

Selection for meat production in dual-purpose cattle can be based on performance and progeny tests. In this paper profitability of performance testing is studied.

Gravert and RosenHAHN (1965) and Niebel et al. (1972) have shown that growth rate is the major trait in selection for meat production. Growth rate of the live animal can be measured and has a high heritability. Therefore in selection for growth rate performance testing can be used. Also carcass characteristics may be assessed in the live animal with a scoring system (DE BOER 1973) or by ultrasonic measurement (BeCh ANDERSEN and ERNST 1972).

The profitability of performance-test selection for growth rate in addition to selection for milk has been studied amongst others by LiNDHé (1968), Hinks (1970), Haring (1972) and Petersen et al. (1973).

Beef crossing in the dual-purpose population will influence the optimum breeding scheme and the relative importance of milk-production and meat-production traits for selection within the dual-purpose population (CunNingham, McClintock 1972). By changing the sex ratio as described by KNAACK et al. (1973) an even higher proportion of the dual-purpose cows can be set apart for beef crossing. In this paper a method is developed to define an aggregate genotype to be selected for when meat-production traits are expressed in several commercial categories of slaughter animals.

The profitability of performance testing is studied including the effect of beef crossing on it. In an example the different aspects are illustrated.

\section{Methods}

\section{Discounted expression per cow}

To estimate the economic value of genetic improvement in meat-production traits (meat traits) the method of Brascamp (1973a) is extended. This method dealt with milk-production traits (milk traits). Its basic feature is the number of offspring in 
subsequent generations in which genetic superiority of selected parents is expressed. How to derive this number of offspring is given in the Appendix. The symbols given there are used in the text.

For different batches of offspring a discount factor should be calculated for the time interval between year zero and the time when animals in the batch show the genetic superiority.

The number of offspring in each batch which show genetic superiority is multiplied by the appropriate discount factor and by the genetic relationship between the animals in the batch and the selected parents.

The results for all batches added together give the value of one unit of genetic superiority of the parents, expressed in money, for a population of $\mathrm{N}$ cows in year zero. The birth of a batch of young bulls is taken as year zero in this paper. The value for the population of $\mathrm{N}$ cows devided by $\mathrm{N}$ is indicated here as 'discounted expression per cow' $\left(E_{j k}\right)$ for parent group $j$ and trait $k$. Parent groups (paths) are sires to breed sons (SS), sires to breed daughters (SD), dams to breed sons (DS) and young bulls (YB). The value $E_{j k} /(1-k)$ where $k$ is the proportion beef crossing, was used by MCCiIntock and CunNingham (1972) and is called number of standard discounted expressions (per dairy insemination).

Now the economic value of a trait $k$ in an aggregate genotype can be defined as

$$
a_{j k}=a_{k}^{\prime} \cdot E_{j k}
$$

where $a_{j k}$ is the discounted economic value of trait $k$ for path $j$ and $a_{k}^{\prime}$ is the value of trait $\mathrm{k}$ in actual money units.

Because different categories of slaughter animals are slaughtered at different ages, the discounted expressions for meat traits are given together for all categories when the calves are born $\left(\mathrm{E}^{\prime}{ }_{\mathrm{jk}}\right)$. So the slaughter age has not been included in the discounted expressions for meat traits.

For more categories, $E_{i j}^{\prime}$ should be split up over the categories. The economic value $a_{j k l}$ of trait $k$ for category $l$ and path $j$ can be expressed as follows

$$
a_{i k l}=a_{k}^{\prime} \cdot E_{j k}^{\prime} \cdot f_{1} \cdot\left(\frac{1}{1+r}\right)^{n_{1}}
$$

where $f_{1}$ is the proportion of slaughter animals in category $l, n_{1}$ is the time interval between birth and slaughter of animals in category $l$ and $r$ is the interest rate. Now an aggregate genotype can be defined in which each trait for different categories is a separate element.

For each path a selection index can be derived and the monetary return from selection over path $\mathfrak{j}\left(R_{j}\right)$ is equal to

$$
\mathrm{R}_{\mathrm{i}}=\mathrm{i}_{\mathrm{j}} \cdot \sigma_{\mathrm{I}_{\mathrm{j}}}
$$

where $i_{j}$ is the selection intensity in standard deviation units for path $j$ and $\sigma_{1 j}$ is the standard deviation of the index for path $j$. Because the economic values in the aggregate genotype are discounted to year zero and are defined per cow, $\mathbf{R}_{\mathbf{j}}$ will represent the monetary return per cow resulting from selection over path $j$ also discounted to year zero.

The same applies to the standard deviations of selection indices used further in this paper.

\section{Beef crossing}

The maximum proportion of beef crossing $(\mathrm{k})$ in a dual-purpose population depends on the replacement rate in the dairy herd $(1 / C)$ and on the proportion of calves that 
survive up to the productive age (s). Furthermore the sex ratio will influence $k$. The following relation holds

$$
(1-\mathrm{k}) \cdot \mathrm{s} \cdot \mathrm{F} \geqq 1 / \mathrm{C}
$$

where $\mathrm{F}$ is the proportion of female calves born.

$$
\text { So } \mathrm{k}_{\max }=1-\frac{1}{\mathrm{C} \cdot \mathrm{s} \cdot \mathrm{F}}
$$

\section{Returns from selection after performance test}

Performance-test selection is assumed to be accomplished before progeny test inseminations are done.

The net return from selection among young bulls whose performance has been tested is the difference between returns from this selection and the costs for performance test; its effects on the return from selection for milk traits are also considered.

Net return from performance-test selection consists of the following:

1. gross return from selection among young bulls (path YB)

2. costs for performance testing

3. loss in selection response for path DS

4. returns over paths $\mathrm{SS}$ and $\mathrm{SD}$

5. loss over paths SS and SD ad 1:

$$
\mathrm{R}_{\mathrm{YB}}=\mathrm{i}_{\mathrm{YB}} \cdot \sigma_{\mathrm{I} B}
$$

where $i_{Y B}$ is the selection intensity for the proportion selected after the performance test, $\mathrm{PYB}$.

ad 2: If after the performance test there is no selection (selection $1: 1$ ) the costs for the performance test, expressed per cow, only depend on the number of young bulls to be progeny tested for milk traits. These costs per cow are symbolized by $c_{1}$. If a fraction $\mathrm{PYB}_{\mathrm{B}}$ is selected after the performance test (selection $1: 1 / \mathrm{p}_{\mathrm{YB}}$ ), the costs for performance testing are $c_{1} / p_{Y B}$.

ad 3:

$$
\Delta R_{\mathrm{DS}}=\left(\mathrm{i}_{\mathrm{DS}}-\mathrm{i}_{\mathrm{DS}}{ }^{\prime}\right) \cdot \sigma_{\mathrm{I}_{\mathrm{DS}}}
$$

where $\Delta R_{D S}$ is the decrease in returns from DS selection when the number of young bulls for performance test exceed the number for progeny test. The selection intensities $i_{D S}$ and $i_{D S}^{\prime}$ apply for a selected proportion of pDs and $\mathrm{PDS} / \mathrm{p}_{\mathrm{YB}}$, respectively.

ad 4: The selection response over paths SS and SD will increase by including the results of performance testing in the selection indices for path SS and SD. This increase is symbolized by $\mathrm{R}_{\mathrm{s}}$.

ad 5: If selection is done after performance testing the variance of correlated traits will decrease, and there will be a loss in returns from selection over path SS $\left(\Delta \mathbf{R}_{\mathrm{Ss}}\right)$

$$
\Delta \mathrm{R}_{\mathrm{SS}}=\mathrm{i}_{\mathrm{SS}} \cdot\left(\sigma_{\mathrm{I}_{\mathrm{SS}}}-\sigma_{\mathrm{I}_{\mathrm{SS}}}\right)
$$
The standard deviations of the index $\sigma_{\mathrm{ISS}}$ and $\sigma_{\mathrm{I}_{\mathrm{SS}}}$ apply for the situations with
$\mathrm{p}_{\mathrm{YB}}=1$ and $\mathrm{p}_{\mathrm{YB}} \neq 1$, respectively.

$$
\sigma_{{ }_{S S}}^{\prime}=\sigma_{I_{S S}} \cdot \sqrt{1-r^{2}{ }_{{ }_{1}{ }_{Y B} I_{S S}} \cdot i_{Y B} \cdot\left(i_{Y B}-x\right)}
$$


where $\mathrm{r}$ is a correlation coefficient and $\mathrm{x}$ is the point on the absciss in a standard normal distribution at truncation selection of a fraction $\mathrm{p}_{\mathrm{YB}}$.

For path SD the same relation holds.

$$
\begin{gathered}
\text { If } \mathrm{r}_{\mathrm{I}}{ }_{\mathrm{YB}^{I_{S S}}}=\mathrm{I}_{\mathrm{I}_{\mathrm{YB}} \mathrm{I}_{\mathrm{SD}}}=\mathrm{r} \text { then } \\
\Delta \mathrm{R}_{\mathrm{S}}=\Delta \mathrm{R}_{\mathrm{SS}}+\Delta \mathrm{R}_{\mathrm{SD}}=\left(\mathrm{i}_{\mathrm{SS}} \cdot \sigma_{\mathrm{I}_{\mathrm{SS}}}+\mathrm{i}_{\mathrm{SD}} \cdot \sigma_{\mathrm{I}_{\mathrm{SD}}}\right)\left(1-\sqrt{\left.1-\mathrm{r}^{2} \cdot \mathrm{i}_{\mathrm{YB}}\left(\mathrm{i}_{\mathrm{YB}}-\mathrm{x}\right)\right)}\right.
\end{gathered}
$$

Net return from performance-test selection $\left(N_{R_{P T}}\right)$ is equal to

$$
\mathrm{NR}_{\mathrm{PT}}=\mathrm{R}_{\mathrm{YB}}-\mathrm{c}_{1} / \mathrm{PYB}_{\mathrm{P}}-\Delta \mathrm{R}_{\mathrm{DS}}+\mathrm{R}_{\mathrm{S}}-\Delta \mathrm{R}_{\mathrm{S}}
$$

\section{Results}

\section{Discounted expression per cow}

In table 1 the discounted expressions for milk traits are given for different paths and different levels of $y$, which is the proportion of dual-purpose inseminations with young bulls. The assumptions behind the calculations have been given before by Brascamp (1973a).

\section{Table 1}

Discounted expression per cow for milk traits for the paths SS, SD and YB dependent on the proportion of dual-purpose inseminations with young bulls $(y)$

\begin{tabular}{|l|c|c|c|c|c|c|}
\hline path & $y=0.10$ & $y=0.20$ & $y=0.30$ & $y=0.50$ & $y=0.70$ & $y=0.90$ \\
\hline SS & 0.0756 & 0.0785 & 0.0816 & 0.0880 & 0.0953 & 0.1036 \\
SD & 0.2131 & 0.1945 & 0.1752 & 0.1339 & 0.0867 & 0.0315 \\
YB & 0.3165 & 0.3292 & 0.3423 & 0.3704 & 0.4024 & 0.4397 \\
\hline
\end{tabular}

The discounted expressions for the DS path are not given being half the discounted expressions for path YB, as follows from the model.

In table 2 the discounted expressions for meat traits are given, which not only depend on $y$, as do the expressions for milk traits, but also on $\mathrm{k}$. As mentioned before,

\section{Table 2}

Discounted expression per cow for meat traits for the paths SS, SD and YB dependent on the

\begin{tabular}{|c|c|c|c|c|c|c|c|c|c|}
\hline \multirow{2}{*}{$\mathbf{y}$} & \multicolumn{3}{|c|}{ SS } & \multicolumn{3}{|c|}{ SD } & \multicolumn{3}{|c|}{ YB } \\
\hline & $k=0.0$ & $k=0.1$ & $\mathrm{k}=0.2$ & $k=0.0$ & $k=0.1$ & $k=0.2$ & $k=0.0$ & $k=0.1$ & $k=0.2$ \\
\hline 0.1 & 0.0766 & 0.0680 & 0.0593 & 0.2102 & 0.1876 & 0.1650 & 0.3208 & 0.2859 & 0.2510 \\
\hline 0.2 & 0.0802 & 0.0712 & 0.0621 & 0.1879 & 0.1676 & 0.1474 & 0.3362 & 0.2996 & 0.2631 \\
\hline 0.3 & 0.0838 & 0.0743 & 0.0649 & 0.1654 & 0.1475 & 0.1296 & 0.3517 & 0.3134 & 0.2752 \\
\hline 0.5 & 0.0910 & 0.0807 & 0.0704 & 0.1196 & 0.1066 & 0.0936 & 0.3830 & 0.3413 & 0.2996 \\
\hline 0.7 & 0.0982 & 0.0871 & 0.0760 & 0.0728 & 0.0648 & 0.0569 & 0.4146 & 0.3694 & 0.3242 \\
\hline 0.9 & 0.1053 & 0.0933 & 0.0814 & 0.0247 & 0.0219 & 0.0192 & 0.4468 & 0.3979 & 0.3491 \\
\hline
\end{tabular}
fraction of beef inseminations (k) and the proportion of dual-purpose inseminations with young bulls (y) 
the discounted expressions for meat traits are calculated for all categories of slaughter animals together, excluding a discount factor for the period birth to slaughter.

For the calculation of monetary returns the absolute values of the discounted expressions are relevant. For an appropriate weighing of milk against meat traits, only the ratio of the discounted expressions is important. These ratios are given in table 3, for the paths SS, SD and YB. In agreement with Cunningham and McCinTOCK (1972) this ratio increases with increasing $\mathrm{k}$.

Table 3

The ratio between the discounted expressions per cow for milk and meat traits for the paths SS, SD and YB dependent on $k$ and $y$

\begin{tabular}{|c|ccc|c|c|c|c|}
\hline \multirow{2}{*}{} & \multicolumn{2}{|c|}{ SS } & \multicolumn{2}{c|}{ SD } & \multicolumn{2}{|c|}{ YB } \\
& $\mathrm{k}=0$ & $\mathrm{k}=0.20$ & $\mathbf{k}=0$ & $\mathrm{k}=0.20$ & $\mathbf{k}=0$ & $\mathbf{k}=0.20$ \\
\hline 0.10 & 0.986 & 1.274 & 1.014 & 1.292 & 0.987 & 1.261 \\
0.50 & 0.966 & 1.248 & 1.119 & 1.430 & 0.967 & 1.236 \\
0.90 & 0.984 & 1.272 & 1.276 & 1.637 & 0.984 & 1.260 \\
\hline
\end{tabular}

Its value not only depends on $\mathrm{k}$ but, especially for path SD, also on $y$. Furthermore the ratios prove to be different per path, especially SD compared to SS and YB.

The discounted expressions are calculated with the assumption that the probabilities for an offspring of a young bull (A) and of a proven bull (B) to enter the dairy herd are not equal and functions of $y$ (see Appendix). Assuming $A=B=1 / C$ one finds ratios which are independent of $y$ and of the path.

\section{Beef crossing}

The calculations in this section have been made with assumption that the actual beef crossing is near the maximum so that the relation $\mathrm{A}=\mathrm{B}=1 / \mathrm{C}$ is more realistic.

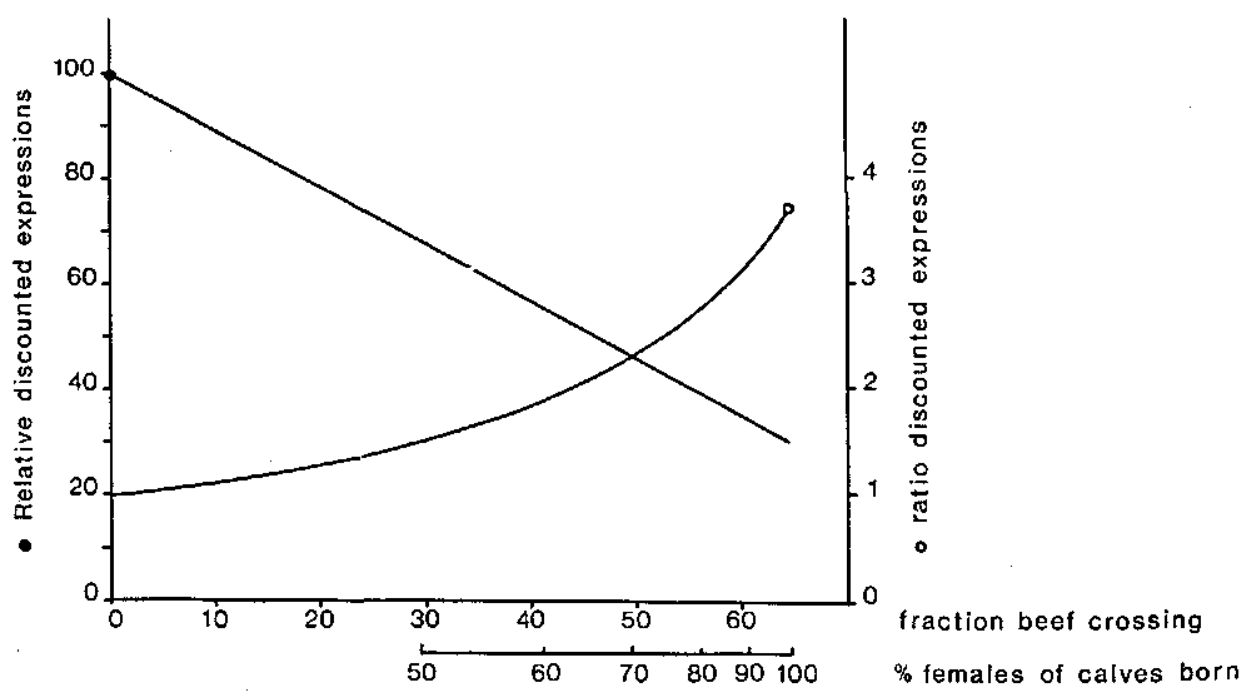

Fig. 1 
In figure 1 the relation is given between $\mathrm{k}$ and the discounted expressions per cow for meat traits. If dual-purpose inseminations would only give female offspring and $k$ is maximum, the discounted expression is $30 \%$ of the discounted expression for $k=0$; genetic superiority of dual-purpose bulls for meat traits is expressed in crossed animals only, when $\mathrm{k}$ is a maximum. When the correlations between milk and meat traits are zero, the relation between $\mathrm{k}$ and the discounted expressions for meat traits also represent the relation between $k$ and gross returns from performance-test selection expressed in meat.

With increasing $\mathrm{k}$ the emphasis on milk and meat in the aggregate genotype shifts to milk traits. So when the correlations between milk and meat traits are not zero, the gross returns from performance testing as a function of $\mathrm{k}$ can be lower than given in figure 1.

Also in figure 1 the ratio between the discounted expressions for milk traits and meat traits, as a function of $\mathrm{k}$, are given.

\section{Returns from performance-test selection and the optimum proportion selected}

Figure 2 shows how the optimum proportion selected $\left(1: 1 / \mathrm{p}_{\mathrm{YB}}\right)$ is influenced 1 . by the ratio of the standard deviations of the selection index for paths DS and YB, respectively, 2 . by the proportion selection for path DS when $\mathrm{P}_{\mathrm{YB}}=1$ and 3 . by the costs per cow for performance testing $\left(c_{1}\right)$ when $\mathrm{p}_{\mathrm{YB}}=1$. (Example: If 1 young bull per 5000 cows is progeny tested and the costs for performance-testing of one bull, discounted to year zero, amount to Hfl. $1000 c_{1}$ is Hfl. 0.20 ). Most combinations of factors which affect the optimum proportion selected, result in a PYB larger than 1 in 5 . When DS are selected with low selection intensity, the optimum $\mathrm{p}_{Y B}$ is always more than 1 in 4 .

The net returns which correspond to figure 2 are given in table 4 , for $\sigma_{\mathrm{I}}=100$.

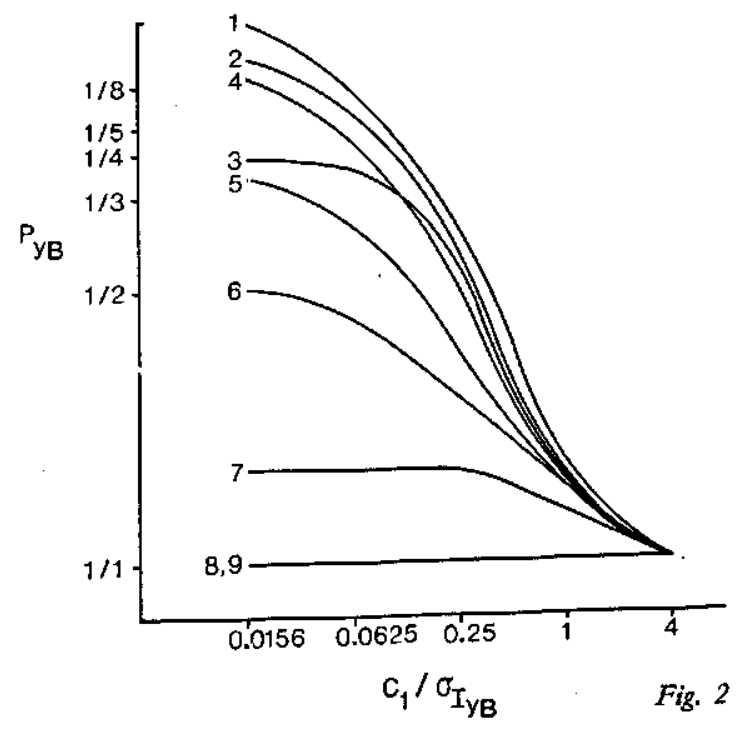

Examples

In the Netherlands there are three main categories of cattle for slaughter: culled dairy cows, veal calves and beef cattle. Beef cattle include steers, bulls and heifers. As in the Appendix it is assumed that performance-test selection does not affect the net income from slaughtered dairy cows.

In this example meat traits are restricted to growth rate and milk traits to milk yield. The genotype for milk yield is symbolized by $G_{1}$, for growth rate in veal calves by $G_{2}$ and for growth rate in beef cattle by $G_{3}$. The genotype for growth rate under conditions of performance testing is $G_{P T}$. The aggregate genotype consists of $G_{1}, G_{2}$ 
and $G_{3}$. Except for the genetic correlations, the parameters needed to derive selection indices are given in table 5 .

For the growth rate under performance-test conditions it has been assumed that $\mathrm{h}^{2}=0.50$ and $\sigma_{\mathrm{G}}=70 \mathrm{~g} /$ day.

Table 4

Net return from performance-test selection dependent on the costs for performance test and on the loss in selection response over path DS $\left({ }^{\sigma}{ }_{1 Y \mathrm{~B}}=100\right)$

(for the symbols used see figure 2)

\begin{tabular}{|c|c|c|c|c|c|c|}
\hline \multirow{2}{*}{$\sigma^{\sigma_{\mathrm{DS}}} / \sigma_{\mathrm{I}} \mathrm{YB}$} & \multirow[t]{2}{*}{ PDS } & \multicolumn{5}{|c|}{$c_{1} / \sigma_{I_{Y B}}$} \\
\hline & & 4 & 1 & 0.25 & 0.0625 & 0.0156 \\
\hline \multirow[t]{3}{*}{.25} & .001 & 0 & 10 & 53 & 106 & 153 \\
\hline & .064 & 0 & 9 & 49 & 95 & 128 \\
\hline & .256 & 0 & 8 & 44 & 77 & 90 \\
\hline \multirow[t]{3}{*}{1.00} & .001 & 0 & 6 & 35 & 68 & 91 \\
\hline & .064 & 0 & 3 & 25 & 44 & 60 \\
\hline & .256 & 0 & 0 & 16 & 27 & 30 \\
\hline \multirow[t]{3}{*}{4.00} & .001 & 0 & 0 & 5 & 9 & 9 \\
\hline & .064 & 0 & 0 & 0 & 0 & 0 \\
\hline & .256 & 0 & 0 & 0 & 0 & 0 \\
\hline
\end{tabular}

Selection after performance test will be based upon an index consisting of the phenotypic value under performance test conditions $P_{\mathrm{PT}}$; dams to breed sons will be selected according to an index with the phenotypic value for milk yield; SS and SD according to an index consisting of the average milk yield of a progeny group of 100 daughters and $\mathrm{P}_{\mathrm{PT}}$. The selection of SS and SD is 1 in 5.

Table 5

Parameters used to deiver selection indices for paths SS, SD, DS and YB

\begin{tabular}{|ll|c|c|c|}
\hline $\begin{array}{c}\text { Traits in aggregate } \\
\text { genotype }\end{array}$ & $\begin{array}{c}\text { genotypic standard } \\
\text { deviation }\end{array}$ & $\begin{array}{c}\text { economic } \\
\text { value (Hfl.) }\end{array}$ & beritability \\
\hline milk yield & $G_{1}$ & $450 \mathrm{~kg} /$ lactation & 0.25 & 0.25 \\
growth rate: veal $\mathrm{G}_{2}$ & $\begin{array}{r}50 \mathrm{~g} / \text { day } \\
77 \mathrm{~g} / \text { day }\end{array}$ & 0.25 & 0.50 \\
& beef $\mathrm{G}_{3}$ & 1.00 & 0.50 \\
\hline
\end{tabular}

The economic values for path $\mathfrak{j}$ for growth rate in veal calves and beef cattle are $0.25 \cdot \mathrm{E}^{\prime}{ }_{\mathrm{j} 2} \cdot \mathrm{f}_{1} \cdot 0.96$ and $1.00 \cdot \mathrm{E}_{\mathrm{j} 2}^{\prime} \cdot \mathrm{f}_{2} \cdot 0.83$, respectively.

In the Netherlands $f_{1}$ is 0.70 .

In table 6 the optimum proportion selected are given at different genetic correlations between traits. Also net returns are given (the performance test with $p_{Y B}=1$ costs Hfl. 0.20 per cow).

In these examples the correlations between the different growth-rate genotypes are supposed to be equal and also the correlations between the growth rate genotypes and the genotype for milk yield.

In table 7 results are given for the same calculations when the only category of slaughter animals were beef cattle $\left(f_{1}=0\right)$.

A comparison of tables 6 and 7 show that the results are strongly influenced by the low economic value and the genetic standard deviation for growth rate in veal calves. 
Also the values of the genetic correlations influence the results to such an extent that accurate parameter estimation is necessary.

However, it may be questioned whether such minor differences in genetic correlations can be shown by statistical analyses (compare e.g. Mason et al. 1972).

\section{Table 6}

Optimum proportion selected (PYB) after performance test and net return per cow dependent on the fraction of beef inseminations (k), proportion selected for path DS (PDS), the genetic correlation between growth rates under different conditions $\left(r_{\mathrm{gg}}\right)$ and the genetic correlation between milk yield and growth tate $\left(r_{\mathrm{mg}}\right)$. The fraction of veal calves of slaughter animals is 0.70

\begin{tabular}{|c|c|c|c|c|c|c|c|c|c|c|c|c|c|}
\hline \multirow[b]{3}{*}{$r_{\mathrm{mg}}$} & \multirow[b]{3}{*}{$r_{g B}$} & \multicolumn{6}{|c|}{ Proportion sclected } & \multicolumn{6}{|c|}{ Net Return (Hil.) } \\
\hline & & \multicolumn{2}{|c|}{$k=0$} & \multicolumn{2}{|c|}{$\mathrm{k}=0.20$} & \multicolumn{2}{|c|}{$\mathbf{k}=0.35$} & \multicolumn{2}{|c|}{$\mathrm{k}=0$} & \multicolumn{2}{|c|}{$k=0.20$} & \multicolumn{2}{|c|}{$k=0.35$} \\
\hline & & $0.05^{1}$ & 0.005 & 0.05 & 0.005 & 0.05 & 0.005 & 0.05 & 0.005 & 0.05 & 0.005 & 0.05 & 0.005 \\
\hline 0 & 1 & $2^{2}$ & 4 & $11 / 2$ & 2 & $11 / 2$ & 2 & 2.20 & 3.32 & 1.04 & $1.71^{\circ}$ & 0.38 & 0.80 \\
\hline 0 & 0.8 & $11 / 2$ & 3 & $11 / 2$ & 2 & $*$ & $11 / 2$ & 1.13 & 1.82 & 0.43 & 0.85 & $*$ & 0.33 \\
\hline 0 & 0.6 & $11 / 2$ & 2 & $*$ & $11 / 2$ & * & $*^{2}$ & 0.33 & 0.71 & & 0.23 & $*$ & $*$ \\
\hline-0.1 & 0.8 & $1^{\prime 2}$ & $11 / 2$ & 1 & 1 & $*$ & * & 0.16 & 0.26 & 0.01 & 0.01 & $*$ & * \\
\hline-0.2 & 0.8 & 1 & $1^{72}$ & * & * & $*$ & * & 0.10 & 0.10 & * & $*$ & $*$ & $*$ \\
\hline 0.1 & 0.8 & 3 & 4 & 2 & 3 & 2 & 3 & 2.92 & 4.49 & 1.90 & 2.91 & 1.22 & 2.13 \\
\hline 0.2 & 0.8 & 4 & 6 & 3 & 6 & 3 & 5 & 5.29 & 7.58 & 4.05 & 6.03 & 3.08 & 4.89 \\
\hline
\end{tabular}

\section{Table 7}

Optimum proportion selected after performance test (pYB) and net return per cow dependent on pDs, $r_{\mathrm{mg}}$ and $\mathbf{r}_{\mathrm{gg}}$. The fraction veal calves of slaughter animals is 0

(for symbols used see table 6)

\begin{tabular}{|c|c|c|c|c|c|c|c|c|c|c|c|c|c|}
\hline \multirow[b]{3}{*}{$\mathrm{I}_{\mathrm{mg}}$} & \multirow[b]{3}{*}{${ }^{r_{8 g}}$} & \multicolumn{6}{|c|}{ Proportion selected } & \multicolumn{6}{|c|}{ Net teturn (Hfl.) } \\
\hline & & \multicolumn{2}{|c|}{$k=0$} & \multicolumn{2}{|c|}{$\mathrm{k}=0.20$} & \multicolumn{2}{|c|}{$\mathrm{k}=0.35$} & \multicolumn{2}{|c|}{$k=0$} & \multicolumn{2}{|c|}{$k=0.20$} & \multicolumn{2}{|c|}{$k=0.35$} \\
\hline & & 0.05 & 0.005 & 0.05 & 0.005 & 0.05 & 0.005 & 0.05 & 0.005 & 0.05 & 0.005 & 0.05 & 0.005 \\
\hline 0 & 1 & 6* & 6 & 5 & 6 & 3 & 6 & 13.83 & 16.42 & 8.67 & 11.15 & 5.22 & 7.24 \\
\hline 0 & 0.8 & 5 & 6 & 4 & 6 & 3 & 4 & 9.11 & 11.62 & 5.40 & 7.46 & 3.07 & 4.51 \\
\hline 0 & 0.6 & 3 & 6 & 2 & 4 & 2 & 3 & 4.95 & 6.89 & 2.69 & 4.03 & 1.38 & 2.23 \\
\hline-0.1 & 0.8 & 5 & 6 & 2 & 4 & $11 / 2$ & 2 & 6.58 & 8.63 & 3.12 & 4.45 & 1.75 & 2.18 \\
\hline-0.2 & 0.8 & 3 & 4 & $11 / 2$ & 2 & $1^{\prime 2}$ & 1 & 4.22 & 5.53 & 1.53 & 2.03 & 0.67 & 0.67 \\
\hline 0.1 & 0.8 & 6 & 6 & 5 & 6 & 4 & 6 & 11.69 & 11.43 & 7.93 & 10.50 & 5.37 & 7.57 \\
\hline 0.2 & 0.8 & 6 & 6 & 6 & 6 & 5 & 6 & 14.18 & 17.07 & 10.74 & 13.56 & 7.94 & 10.62 \\
\hline
\end{tabular}

\section{Discussion}

The discounted expressions per cow, or per dairy insemination, show the same trend in dependency on $\mathrm{k}$ as the numbers of standard discounted expressions of CunNingHAM and MCCLINTOCK (1972), when both concepts are defined on the same basis, e.g. per cow or per dairy insemination. In their model; $y$, the proportion of dual-purpose inseminations with young bulls, is not a variable. However, here it has been shown that the discounted expressions also depend on $y$. 
Predicting the monetary return from index selection and ignoring $y$ from the model, will give biased estimates; for example, the selection response for path SD will be overestimated (tables 1 and 2).

If only ranking of animals is of interest, the ratio between discounted expressions for milk and meat traits should be considered. This ratio is only unaffected by $y$ if the probabilities for offspring of young bulls and for proven bulls to enter the dairy herd are equal (table 8 ). In practice always more females will be available for replacement than are needed, and the assumption of equal probabilities usually will not hold.

By incorporating the discounted expressions for different traits and paths in the economic values of the traits in an aggregate genotype, the monetary return from a breeding programme discounted to year zero can be calculated.

\section{Table 8}

Discounted expressions for milk and meat traits and their ratio for the paths SS and SD at different levels of the proportion of dual-purpose inseminations with young bulls $(y)$

$$
(A=B=1 / C \text {, see text) }
$$

\begin{tabular}{|c|ccc|c|c|c|c|}
\hline \multirow{2}{*}{$\mathrm{y}$} & \multicolumn{2}{|c|}{ millk traits } & \multicolumn{2}{|c|}{ meat traits } & \multicolumn{2}{c|}{ tatio } \\
& SD & Ss & SD & SS & SD & Ss \\
\hline 0.1 & 0.2090 & 0.0762 & 0.2100 & 0.0766 & 0.995 & 0.995 \\
0.5 & 0.1180 & 0.0904 & 0.1186 & 0.0908 & 0.995 & 0.995 \\
0.9 & 0.0240 & 0.1047 & 0.0241 & 0.1052 & 0.995 & 0.995 \\
\hline
\end{tabular}

For one trait this calculation has been done by BRASCAMp (1973a): the weighing factors for genetic superiority for milk yield of different parent-groups were used to evaluate the economic value of genetic improvement. These weighing factors will equal the discounted expressions recorded in table 1.

Of the five factors which affect the net return from performance testing, the response from selection among progeny-tested bulls will be the least important. In the index to select among tested bulls the milk traits will outweigh the meat traits because the bulls' breeding value for milk traits is estimated more reliably and because the product of the economic value and the genetic standard deviation for milk traits is generally much higher. So the three factors in figure 2 will usually completely determine the profitability of performance testing.

In calculating costs for performance testing it was assumed that the costs increase linearly with increasing selection intensity, which is not absolutely true (LiNDHé 1968). However, the deviations are small.

Comparison of the results of figure 2 with the results from other calculations (Lindhó 1968; Hinks 1970; Haring 1972; Petersen et al. 1971) is difficult, because part of the required information is not available. However, it seems that $\sigma \mathrm{I}_{\mathrm{DS}} / \sigma \mathrm{I}_{\mathrm{YB}}$ usually is near to 1 . For average costs in figure 2 the optimum proportion selected after performance test is 1 in 2 to 1 in 4 .

From figure 2 it can be concluded that more intensive selection after performance testing is justified if costs per cow are lower or if DS are selected more intensively. Both factors mainly are determined by the number of young bulls which are to be progeny tested.

BrASCAMP (1973b) found that breeding programmes for milk traits were optimum with intensive use of proven bulls, and, compared with literature, with few young bulls. With these programmes also the returns from performance testing will be highest. 
In this paper the performance test is taken to be terminated when the young bulls are one year old. Increasing the length of the test period possibly gives higher correlations between the genotypes for meat traits under performance-test conditions and those in the categories of slaughter animals. This gain in returns however, should at least balance the loss in returns caused by longer generation intervals for SS, SD and YB. In the example with the fraction of veal calves equal to zero an increase of the test period by half a year requires a genetic correlation between $G_{P T}$ and $G_{3}$ about 0.35 higher, if the selection is $1: 3$ and 0.20 if the selection is $1: 5$. If the test period is prolonged for 1 year, these figures are about 0.60 and 0.30 , respectively.

\section{Summary}

For the measurement of the monetary returns from breeding schemes in a dual-purpose breed of cattle, with special attention to returns from performance testing, the concept 'discounted expression per cow' has been developed. This concept is similar to the 'number of standard discounted expressions' of McClintock and CunNingham (1972).

Compared to their model an extra variable has been introduced, "viz", the proportion of dualpurpose inseminations with young bulls. The effect of this variable and of the fraction crossbreeding for beef on the discounted expressions has been studied (tables 1 and 2).

The weighing of milk and meat traits in an aggregate genotype to be selected for has been discussed (table 3 and 8 ).

A method has been developed to define an aggregate genotype to be selected for in a situation where the same meat trait is expressed in several categories of slaughter animals. Factors affecting the profitability of performance testing have been studied (figure 2 and table 4).

The financial consequences of increasing the duration of the performance test have been discussed.

\section{Zusammenfassung}

\section{Modellkalkulationen zur Optimierung der Wirtscbaftlicbkeit der KB-Zucbt beim Rind. TeilIII}

Zur Bestimmung des finanziellen Erfolges von Zuchtplänen beim Zweinutzungsrind unter besonderer Berücksichtigung der Eigenleistungsprüfung wurde die Methode "discounted expression per cow" (das entspricht dem Geldwert einer Standardeinheit genetischer Uberlegenheit selektierter Elterntiere) entwickelt. Xhnnlich ist die Methode von McCinTock und CUNNINGHAM (1972) “number of standard discounted expressions". Gegenüber dem letztgenannten Modell wurde eine weitere Variable eingeführt: Der Anteil von Jungbullen bei Besamungen mit einer Zweinutzungsrasse.

Der Einfluß dieser Variablen und des Umfanges der Gebrauchskreuzung zur Fleischerzeugung auf die "discounted expressions" wurde untersucht (Tab. 1 und 2). Die Gewichtung der Merkmale Milch und Fleisch im Gesamtzuchtwert wurde diskutiert (Tab. 3 und 8).

Eine Methode zur Bestimmung des Gesamtzuchtwertes wurde für den Fall entwickelt, daß das eine Merkmal Fleisch durch verschiedene Schlachttierkategorien ausgedrückt wird.

Einflüsse auf die Wirtschaftlichkeit der Eigenleistungsprüfung wurden untersucht (Darst. 2 u. Tab. 4). Die finanziellen Auswirkungen einer vetlängerten Testperiode wurden erörtert.

\section{References}

BECH ANDERSEN, B.; ERNST, E., 1972: Ergebnisse von Ultraschallmessungen an Jungbullen. Zücht.kunde 44, 81-90.

BOER, H. DE, 1973: Working party on „assessment of carcass characteristics in cattle". 24th Ann.

meeting of EAAP, Vienna.
BRASCAMP, E. W., 1973a: Model calculations concerning economic optimalization of AI-breeeing with cattle. I. The economic value of genetic improvement in milk yield. $Z$. Tiezzüchtg. Züchtgsbiol. 90, 1-15.

- 1973b: II. Effect of costs on the optimum breeding plan. Z. Tierzüchtg. Züchtgsbiol. 90, 126-140.

Cochran, W. G., 1951: Improvement by means of selection. Proc. second Berkeley Sym. Math. Stat. and Prob. 449-470.

Cunningham, E.P.; McCintock, A.E., 1972: Selection in dual-purpose cattle populations, Effect of beef crossing and cow replacement rates. Submitted to Ann. Génét. Sél. Anim.

Gravert, H.O.; RosenHaHN, E., 1965: Welche Kriterien sind wirtschaftlich wichtig. Zücht.kunde 37, 244-250. 
KNAack, J.; Nehring, H.; Lorenz, G., 1973: Neue Ergebnisse der experimentellen willkürlichen Geschlechtsbeeinflussung beim Rind. Tierzucht 27, 156-159.

Haring, H. J.F., 1972: Die Zuchtplanung in der Rinderzucht aus ökonomischer Sicht. Diss. Göttingen.

HINKS, C. J.M., 1970: Performance test procedures for meat production amongst dairy bulls used in A.I. Animal. Prod. 12, 577-583.

LiNDHÉ, B., 1968: Model simulation of A.I.-breeding within a dual purpose breed of cattle. Acta Agr. Scand. 18, 33-41.

MASON, I.L.; Vial, V.E.; THOMPSON, R., 1972: Genetic parameters of beef characters and the genetic relationship between meat and milk production in British Friesian cattle. Animal. Prod. 14, 135-148.

McClintock, A.E.; Cunningham, E. P., 1974: Selection in dual-purpose cattle populations: Defining the breeding objective. Anim. Prod. 18, 237-248.

Niebel, E.; RITTLER, A.; Fewson, D., 1972: Die Leistungsmerkmale beim Rind. Teil B: Selektionswürdigkeit der Leistungsmerkmale. Stuttgart: Ulmer.

Petersen, P.H.; Christensen, L.G.; Bech Andersen, B.; Ovesen, E., 1973: Economic optimisation of the breeding structure within a dual-purpose cattle population. Submitted to Acta Agr. Scand.

\section{Appendix}

The numbers of offspring in which genetic superiority of selected parents is expressed.

The underlying model has described in a previous paper (BRASCAMP 1973a).

Symbols used

$\mathrm{d}_{\mathrm{i}}$ : batch of offspring of selected parents in generation $\mathrm{i}$

$D_{i}$ : number of offspring in batch $d_{i}$ entering the dairy herd

$B_{i}$ : number of offspring in batch $d_{i}$ producing meat (not entering the dairy herd)

y: proportion of dual-purpose inseminations with young bulls

$\mathrm{k}$ : proportion of inseminations for beef crossing

A: probability that an offspring of a young bull enters the dairy herd (for $k=0$ )

B: this probability for an offspring of a proven bull

C: average number of lactations per cow

$A^{*}: A /(1-k)$

$B^{*}: \quad B /(1-k)$

$\mathrm{N}$ : population size

s: survival rate up to productive age of dual-purpose offspring

$s^{\prime}$ : survival rate of an offspring from beef crossing

Data

$C=31 / 3$

$A=0.054945 \mathrm{y}^{2}+0.245055 \quad$ or $\mathrm{A}=1 / \mathrm{C}$

$\mathrm{B}=(1 / \mathrm{C}-\mathrm{A} \cdot \mathrm{y}) /(1-\mathrm{y}) \quad$ or $\mathrm{B}=1 / \mathrm{C}$

$\mathrm{s}=\mathrm{s}^{\prime}=0.85$

Number of animals in different batches of offspring path over which

genes are

transmitted to

the next

generation

$\mathrm{YB}$

$\mathrm{d}_{1} \quad \mathrm{~B}_{1}=\mathrm{s} \cdot \mathrm{y} \cdot(1-\mathrm{k}) \cdot \mathrm{N}-\mathrm{D}_{1}=\left(\mathrm{s}-\mathrm{A}^{*}\right) \cdot(1-\mathrm{k}) \cdot \mathrm{y} \cdot \mathrm{N}$

SD $\quad D_{1}=B^{*} \cdot(1-y) \cdot(1-k) \cdot N=B \cdot(1-y) \cdot N$

$\mathrm{d}_{1} \quad \mathrm{~B}_{1}=\mathrm{s} \cdot(1-\mathrm{y}) \cdot(1-\mathrm{k}) \cdot \mathrm{N}-\mathrm{D}_{1}=\left(\mathrm{s}-\mathrm{B}^{*}\right) \cdot(1-\mathrm{k}) \cdot(1-\mathrm{y}) \cdot \mathrm{N}$

$d_{i} \quad D_{i+1}=D_{i}$

$d_{i+1} \quad B_{i+1} \quad$ From dual-purpose bulls:

$\mathrm{d}_{\mathbf{i}+1}$. $\mathrm{D}_{\mathbf{i}} \cdot \mathrm{C} \cdot(1-\mathrm{k}) \cdot \mathbf{s}-\mathrm{D}_{\mathbf{i}}$

From beef bulls:

$\mathrm{D}_{\mathrm{i}} \cdot \mathrm{C} \cdot \mathrm{k} \cdot \mathrm{s}^{\prime}$

$B_{i+1}=D_{i} \cdot\left(C_{k s}^{\prime}-C k s+C s-1\right)$ 


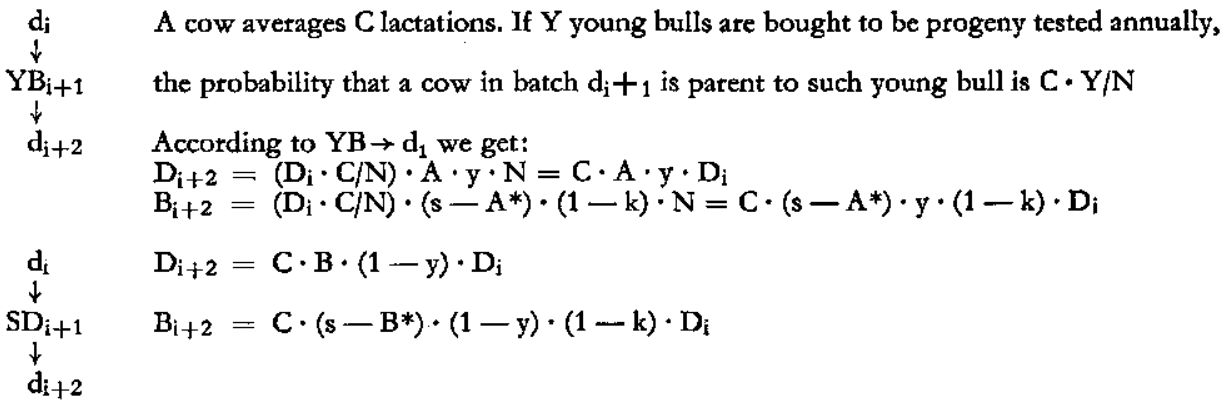

Autbor's address: E.W. BRASCAMp, Dept. of Animal Husbandry, State Agricultural University, Duivendaal 5, Wageningen, The Netherlands 